LA-5324-MS

INFORMAL REPORT

Report of the

Subcommittee on Standard Interface Files

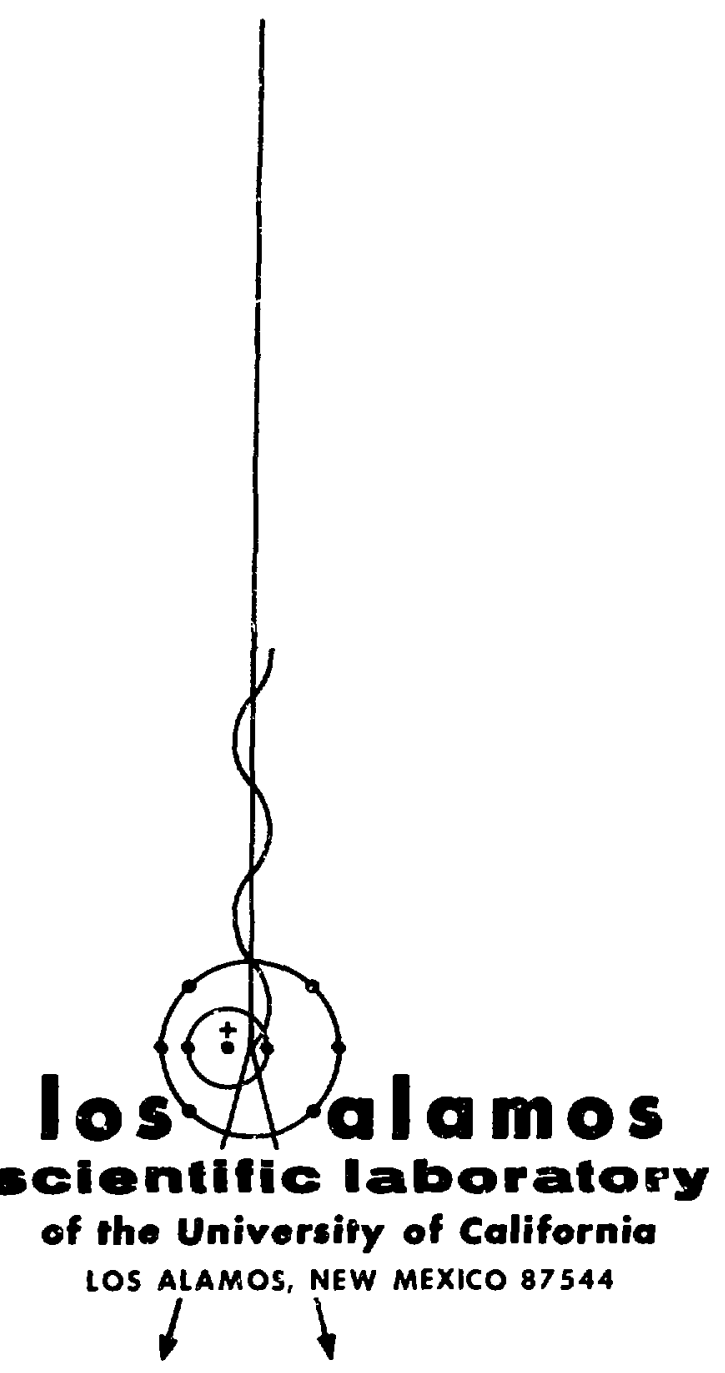


This report was prepared as an account of work sponsored by the United States Government. Neither the United States nor the United States Atomic Energy Commission. nor any of their employees, nor any of theif contraetors, subcontractors, of their employees, makes any warranty, express or im. plied, or assumes any legal liability or responsibility for the accuracy, com. pleteness or usefuiness of any information, apparatus, product or process dis. closed, or represents that its ust would not intringe privately awned rights.

In the interest of prompt distribution, this LAMS report was not edited by the Technical Intormation staft.

Printed in the United Status of America. Available from National Techmicat Intermation Strvise

U. S. Depurtment of Commero: 5285 Port Royal hod Springtiutd. Virgini 22151

Price: Printed Copy 50.00; Mierolich 50.95 
LA.5324.MS

informal Report

UC. 80

ISSUED: July 1973
- Notice

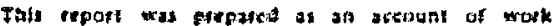

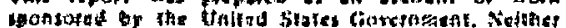

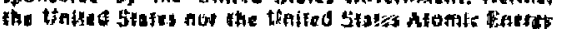

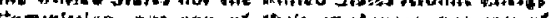

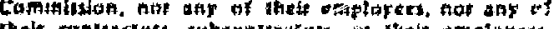

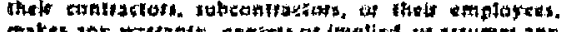

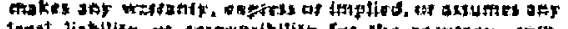

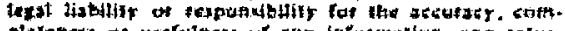

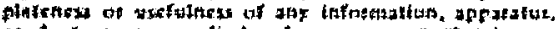

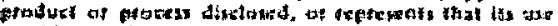

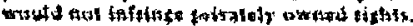

\section{Report of the}

\section{Subcommittee on Standard Interface Files}

Subcommittee Members

B. M. Carmichasal

D. A. Menaley*

D. Vondy"

- Building 208, Argonne National Laboratory, 9700 South Cass St., Argonne. lltinois 60439.

- Oak Pidge National Laboratory, P. O. Box X, Oak Ridge.

Tenmessee 37830

Work performed for Division of Reactor Development and Technology, USAEC. 


\section{ADstract}

Th1: report was informally diatributed originaliy to the Contetee on Computer Code Coordination (CCCC) tor Reactor Fhyalca Codes. Bccause of several requenta recelved, the report is reproduced herelo. It contalne the apecifications for the atandard interface data flles dercloped by the CCCC for applieation to reactor phyates codes. 


\section{INRROIUCTION AND SURATRY}

A principal activity of the Condtes on Cor puter Code Coordinetion he been the developant of - eet of "Stenderd Intcrfece FIIes." Theoe f11a contain the bejor date blocke that wat be tranefarred betreen computor coder in the parformance of Reactor Phyelco celcuiotions. It wer recogntzed early that, if atendaid fore for thace I/O deta files could be esteed upon and inplesented in future codee, wany of the problene eveocieted vith the coordination of cole develepent erd the exchenge of codee between leboretorlee rould be alleviated.

To teat the fensibility of etandardialng I/O Interface filce, the Comatce creatad eet of files for we a interface between a alected eet of Reactor Phyalce coder. The typen of coden conaldared vare croum-eection proceneing codes, neutron tranport and diffusion codes, perturbetion codes, and fuel-cycle codee. Reprebentetive codes In arch of the wbove arene vere chosen for trinl adaptetion to the Interfeces. Teet culculetion performed with the revied codes at the varlou laboratortes prowed the feesblitty of etendard interfacing, but many recormendetion for iprovenent of the prelininary filee vare alpo a by-produce of the teete. A three-on Subcisticee vee then eelected to inplenent these proponed revieton. The work of thie Subcoantete is reported here1n.

Revielone ande to the original files are axtens1ve. The date are aparatod into a laser number of file to provide ane flextbility and efficlency in the use of the filat. A list of the new file none and a general description of the file contente are given in Table $I$. An Identificetion record is pleced at the lieed of each file to factiltate file retrievel. Allowence to ade for the exletence of eeveral veratone of the are itle and for the poesbility thet, at aoe inetalietion, eeveral uere any etore filee on cownon device. Hsth one exception, each file in ande on Independent ontity. This ween thet ach file contalng - epecificetion record inediately following the Identificetion record that containe all tae dienaton parasere and flege osential to the reading of the f1le. Thus, the reading of any given file 1e not contingent upon date contained in any other f11e. The deatcy dete f11e, 2MATN, 1o en excoption to the above. Informetion given In, the nuclide
TABLE I

STADARD INTERFACE TLE NATES AND GENERAL CONTENTS

Nos

ISOTIS Ceneral Deecription of Contente

Huc. Lde-ordered atcroscople broedgroup cross-section data.

GRUPSR Group-orderad microscoplc broad-group crose-zection dace.

CLAYXS Delayed neutron precursor data.

BRKOKS Mrzoscopte croserection data in the gonderenko form.

GEODET Geometry deecription.

NDTGRF Nuclide denst ty and crose-section referencing partheters.

ZNATDN Zone nuclide atcatc densites, includIng aubzone or aubasacably scele.

SEARCH Criticality aearch data.

SNCONS $S_{n}$ conetents.

PIXSRC DLatributed and surface flxed sources. ITFLX Regular total (gcalar) neucron flux.

ATRUX Adjoint total (acalar) neutron flux.

RCURWT Regular neucron current.

ACURT Adjoint neutron current.

RAFLU Regular arguler flux.

ANLUX ldjotnt angular Elux.

RZFLX Regular zone flux by neutron group, avereged over each zone.

PWDINT Power density by interval.

densteg and crose-aetion raferencing file, NDXSRF, net be aviliabie bafore zKATDN cen be uned.

The dete in the filee have been reorganized Into Iarger recorde, abject to core meary conetraints, to pronote file handling efficlenc\%. An afgorith is given in the descripition of each record from which the number of wozds in the record nay be conputed. This facilitates the use of aubroutine celle for trenterting records between core and pertphatel dovicae.

Other date reorgantzation heve been adopted to onke the fller conform wore closely to code ueese, and to provide preater cepability for handling lerge problea. A nultigroup crosemection file, GRUPS, orgentsed by neutron group tether then by Inotope 1. provided alnce cross-eccion dace are normally seored by group in altidinantonal problese. Acom denetty date have been renrenged to expedite the handins of large ntrbere of leotopee in fuel-cycle work. Regular and adjoint deca from flux codes 
have been placed in eeparata filee with different date orgentastions correoponding to the differences between regular and adjolat output from flux codes.

Two f1lies heve been added which contein dete that were not: Included in the old files. Oae of thea 1o the source file, FixsRe, which conteins epecification for diatrlbuted or boundary sources In any of the atandurd geometries. A power density file has aleo been added which provides for epecification of the powr $r$ profile by interval over regione of intereat.

A IIst of the types of codes constilered to date In the davelofiment of Iaterfaces is given in Table II. "Computer Code Interfacing." The function of each type of code 10 deecribed, and l10ts of the 1nput and output interface files raquired by each type of code are shom. It 18 aot latended thet Table II be conoldered a apecification for a code syetes, but rather $1 t$ is a pecification of the atendard files that should be Included in each prototype cade when $2 t$ to prepered ae a free-ptandiag, code for exchenge. Obviourly, when additional codea are added to the current 11ste, the liet of Interface filee w111 require extenoton. liage belence data would be required, for exanple, frum the output of the fuel-cycle code for Input to an economica code, and kinotice paraneters generated by the perturbation code would be meeded in kinetic? calcular ions.

TABLE II

COGPUTER CODE INTERPACING

Descriptive

$$
\text { None }
$$

1. Cross-pection Generator

\section{Generates from reference date} (ENDF-B), or processed intermediate data, afcroscoplc cross sections for broad-energy-group use $i_{\vec{s}}$ add tional calcuiations.

2. Crose-gection Proceseor

3. Neuerontes

4. Fuel-crcle

5. Perturbation
Converts icroscople cross sectlons from nucllde-ordered to neutrongruup-ordered for dimensional neutronics calculations.

Perform neutrontes calculations in up to three-8pace dimensione using one of a number of theoretical approacheo, e.g. finite-difference diffusion or $S_{n}$ transport theory, synthesis.

\begin{tabular}{|c|c|}
\hline \multicolumn{2}{|c|}{$\begin{array}{l}\text { Interface } \\
\text { Itle Naws }\end{array}$} \\
\hline $\begin{array}{c}\text { Data } \\
\text { Supplied }\end{array}$ & $\begin{array}{c}\text { Data } \\
\text { Produced }\end{array}$ \\
\hline ENDF-B & $\begin{array}{c}\text { IsorXs } \\
\text { or } \\
\text { SRKOXS, } \\
\text { DLAYXS }\end{array}$ \\
\hline $\begin{array}{c}\text { Isotxs } \\
\text { or } \\
\text { BRKoxs }\end{array}$ & GRUEXS \\
\hline GRUPXS & RTFLUX \\
\hline GEODST & ATRLUX \\
\hline NDKSRF & RCURNT \\
\hline ZNATDN & ACURNT \\
\hline SEARCH & RAFLUXX \\
\hline SNCONS & AMLUX \\
\hline FIXSRC & R2FLIX \\
\hline RTFLUX & $\begin{array}{l}\text { PWDIRT } \\
\text { GEODST }\end{array}$ \\
\hline & FIXSRC \\
\hline & ZNATDN \\
\hline NDXSRF & NDXSRF \\
\hline 2VATDN & ZNATDN \\
\hline REFLUX & SEARCH \\
\hline GRUPXS & \\
\hline
\end{tabular}

RT PLUX ATE? UXX RCUPHT ACÜRHT RAFLUX AAFLEX DLAYXS GEODST NDXSRF

2HATDY

SNCONS

GRUPXS 
All the new files w11l sequire implementation and zesting in codes for a full evaluation. One new feature that must be teated in the variable blocking capability provided in the group crosuaection files. By means of blocking paranetere in the file epecifications recorda, a prograver any control the nuaber of blocke lato which crosesection arrays are subdivided. Consequently, the content of Individual recorde in the file can be varled to sult the characterlotic dimenalons of a particular cross-gection file. The objactive is to maintain $I / O$ efficiency in the case of analldimengion file whthout reatricting the file copebll1ty for handling large dimenaton. Jariable blocking of all the large arraye in the files vould have advantagea. However, inplonantation of the copability Implies considerable code modification and devielopment. In addition, variable blocking can be accompliahed in a variety of ways and to various degrees. Such policy questions are deferred for future consideration and development.

II. GHNERAL COMARNS ON THE USE OF THE FILES

Euch file contains an Identification record and a upecifications record followed by the records contelning the file data. A typicsl identification record is show below. HWNE is the generic name of obtained frow a ubroutine call to SNIFF or SEEK, such as

CALL SERK(FILNAM, HUSE, IVERS, N1, N2).

SEEK would retrieve N1 from a table that anociates file nemes and veratong with logical unt numbera. In addition, SEBK could position the logical unit correctly for reading or writing the desired file when more than one file Is stacked on the unit. Th1s could be accoraplished by a sucsesetion of calls to the reading oubroutine using

$$
\text { CALI, REED (H1., IREC, A(1), 4, MODE). }
$$

(See Ref. 1 for wore detalled descriptions of SEEK and REED). The REED calls would be repeated unt11 a corraspondence is obtalned between the firat feur words of the $A$ array and FILNAM, HUSE, and IVERS. In writing files, a record signifying the end of date would be requiced in order to avold Fof tests. Such a record wight: include

RDDREC, KUSE, IVBRS.

In the search procedure then ENDRFC = 6HENDREC 18 found in $h(1)$, SEIX would perform one BACKSPACE tr fojition the logital unit for uriting a new file on the undt.

The Specifiliations Record contains in one 11st all the dimenaton and control flaga required for reading the given $111 \mathrm{e}$. Th1s sacilitates the use

\begin{tabular}{|c|c|c|c|}
\hline \multicolumn{3}{|c|}{ FANE, $(\operatorname{HUSE}(I), I-1,2)$, IVERS } & - \\
\hline $\begin{array}{l}\mathrm{CH} \\
\mathrm{C}\end{array}$ & 4 & & - \\
\hline $\begin{array}{l}C D \\
C D \\
C D\end{array}$ & $\begin{array}{l}\text { HNAME } \\
\text { IUSE } \\
\text { IVFRS }\end{array}$ & $\begin{array}{l}\text { HOLLERITH FILE NAE - FILMA - (A6) } \\
\text { HOLLEAITH USIK IDENTIFICATION (A6) } \\
\text { FILE VERSION MUMER }\end{array}$ & 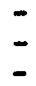 \\
\hline
\end{tabular}

the file which in the exaple to taken to be FILAkM. WSE providea for the posalbility shat wore than one user's flles may be stacked on the ane logical unit. IVERS provides for the occasione where wore than one veraton of a given eype of file le requirad.

The uses to which the identification record would be put are not as yet completely apecified. However, the losical unit number, $\mathrm{N2}$, on which the f11. 1o to be read or writzen would preaunably be of the subroutine calls REED and RITE for reading or writing the file recorde, reopectively. The argunent liate in these aubroutsnes wat contain a apecificacion of the total nuber of words MWD to be cranaferzed and a arazting addraes, $A(I I)$, In core at which the transfer 1s to begin. Consequently, evers record. In the atendard filea has a CW entry which contalne nuber of an elgorithe iros which she number of worde in the record can be conputed. The slgorith is derived tron the dinanelone given in the npecifications Record. 
A record may contain several arrays as in $(A 1(I), I=1, L 1),(A 2(I), I=1, L 2), \ldots$

Let I1, I2, ... be the pointers locating the arrays Al, A2, ..., respectively, in the contalner block A. Then the record 18 read using the following otetementa:

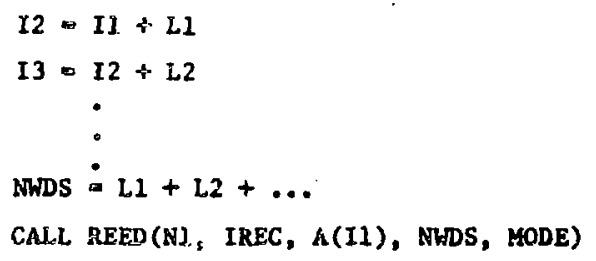

Arrays axe combined in recorde in the above menner in order to promote the efficlency of transfer of the file data.

A technique 18 introduced in the cross-section files for handing arraye which vary greatly in size, deperding upon the application. For exasple, the arrsy

$$
((B(I, J), I=1, I L), J=1, J 1)
$$

containing $I 1 * \mathrm{~J} I$ words may be on occabion too large to store in core. Then the srray could be transferred using NBLOK records, exch containing the number of vords

NWES $=11:((J 1-1) /$ NALOK +1$)$.

The transfers would be accompliehed using DO $n \mathrm{~N}=1$, NBLOK

CALI. REED (N1, IREC,A (1), NHDS, MODE)

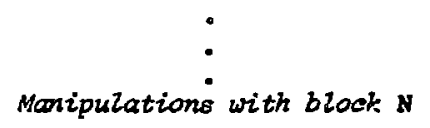

n CONTINUE

In the epplicarion to the crosconection files, the ahove technique is proposed for the fornation of macroncoplc crose ecctione from microscoplc data where a vary large nuber of groups is Involved. Other lerge arraye in the filec atght be hendled aldierly, but a large anount of code developent work would be involved in the inplenentetion of thie epproach.
The orfginal MULTICRF nuclesr data file has been split Into four separate files, Including both: nuclide-ordered and group-ordered microscoplc neutron cross-gection files and separate files for the delayed neutron and Bondarenko data. Cross sections need to be ordered by nuclide for library applicat1ons, but group ordering is tante conventent for code spplications. In multiditienstonal flux codes and in other codes, the macroscopic crose-section date are stored by group to conserve core space. Thus, retrievel of cross sections stored by group should be more conventent and economical. Sorting of the crose sectione by group tould attll be required when they are retrieved from a l1brary or a processing code, but this sorting would need to be done unly once rather than being done in effect each time the cross-section Interface file 18 accessed by a code.

The delayed neutron and Bondarenko data are placed in separate filea to provide more conventent arcess for the limited number of codes that require these data.

The original GRPFL file containing flux code output has been separated Into six f1les. Three of the files contain the regular total $£ 1 u x$, current, and angular flux, and three additional files are defined for the associated sdjoint data. Th1s segregation of the data permits the adjoinc files to be of different structure than the regular files and facilitates sorting of the data.

Considering that, in some applications, several versions of some of the files may exist, the total number of files involved becomes large. Th1s apparently causes no difficulty on some computers but could be prohtbitive on others. Consequently, the promulgation of ihis lerge number of files $1 \mathrm{~s}$ based on an assumption that file hardling coding techniques w1l be evolved that will provide options for arbitrarily stacking files on logical units. A procedure for automatically pooltioning a logical unit on a specified file awong a stacked set using the SEEK routine was diecuened ahove. In addition, a mesno of controlling the stacking optionally stil neede to be evolved and teated. 
III. THE STANDARD INTERFACE FILES

Presented below are the Standard Files with assoclated explanatory comments.

\section{A. ISOTXS}

This file is intended as the basic multigroup library. The 1sotope ordering permits easy addition to the file from a processing code. Three blocking factors are included in order to accommodate large sets while maintaining the desirable feature of few records per 1sotope (minimum of three) for more normal sets. It is expected that the vast mafority of cross-section sets w11l not require multiple blocks. Use of a blocking factor, $N>1$, produces $N$ records, each contalning data for a partial energy group range. If the number of groups is not a multiple of $\mathrm{N}$, the last record w111 contaln some undefined words.

The Identifled entries in the principal crosssection record are intended to cover most practical situations. Additions to or deletions from this list would be extremely simple.

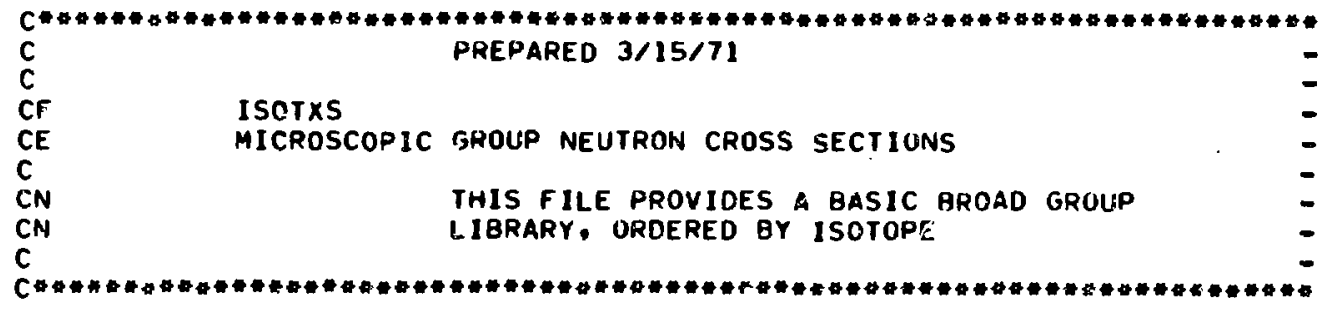

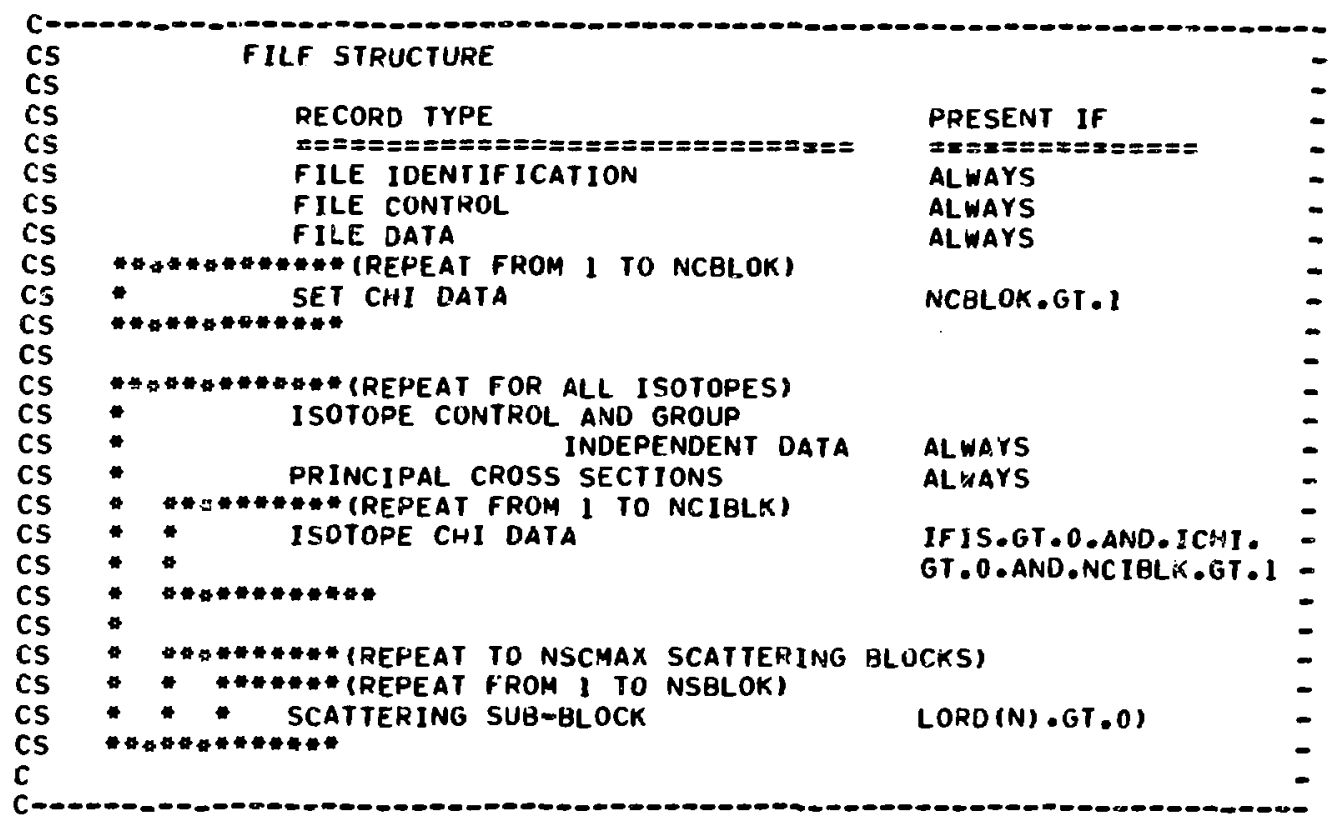

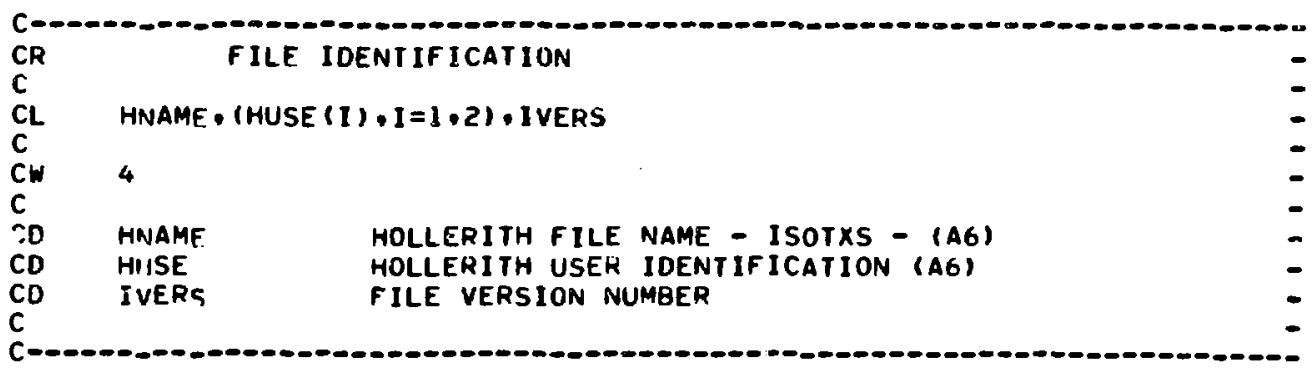




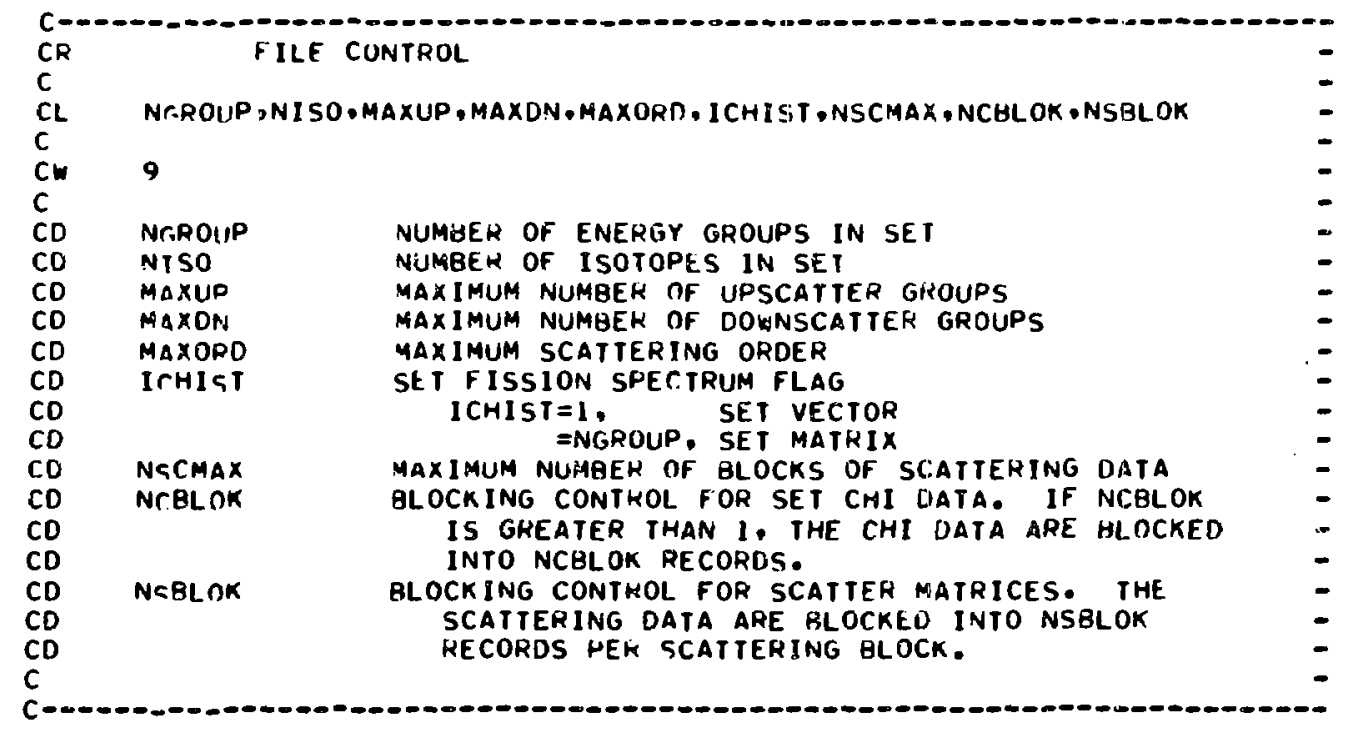

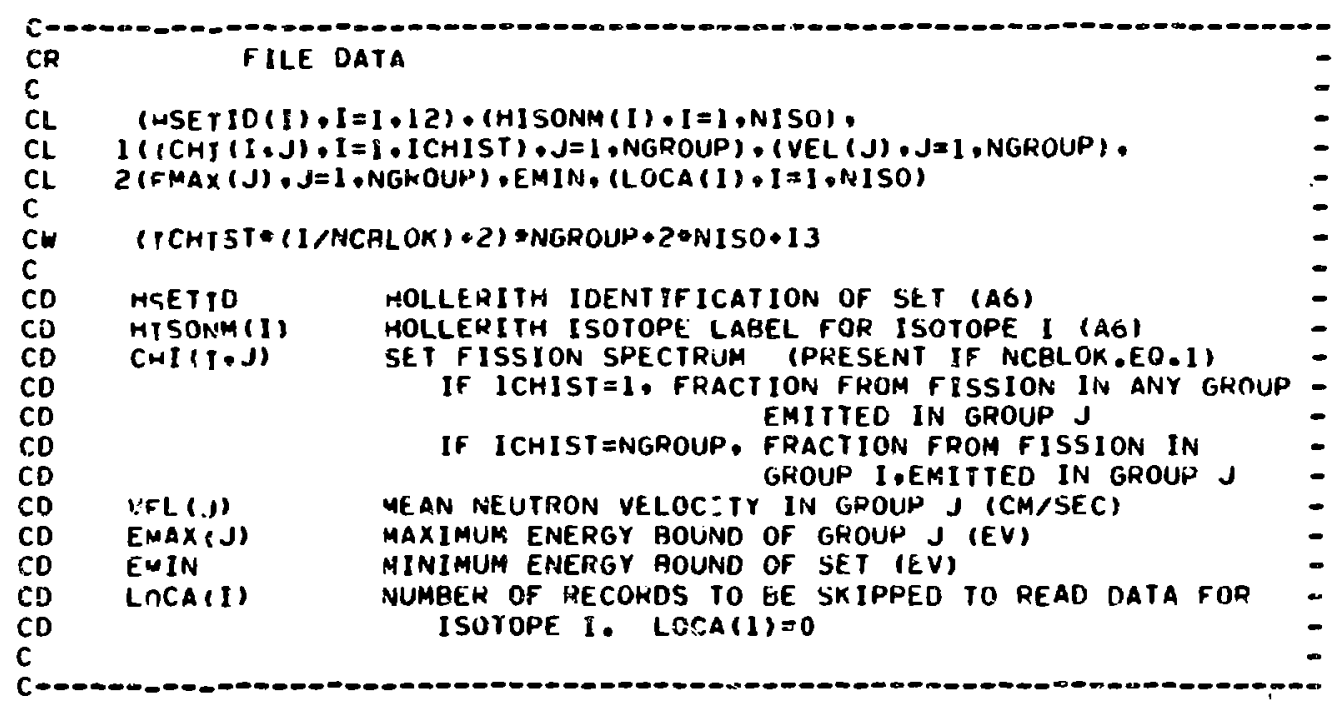

\begin{tabular}{|c|c|c|}
\hline $\begin{array}{l}\text { CR } \\
\text { C }\end{array}$ & SET CHI DAYA & \\
\hline $\begin{array}{l}\mathrm{CC} \\
\mathrm{C}\end{array}$ & PRESENT IF NCBLOK.GT.I & $\overline{-}$ \\
\hline CL & $((C H I(I, J), I=I, I C H I S T), J=J L, J U)$ & - \\
\hline $\begin{array}{l}\mathrm{CC} \\
\mathrm{CC} \\
\mathrm{CC}\end{array}$ & $\begin{array}{l}\text { IF } M \text { IS THE INUEX OF THE CHI SUB-BLOCK, THEN } \\
J L=(M-1)+((N G R O U P-1) / N C E L O K \bullet 1) \bullet 1 \\
\text { AND } J U=M+((N G R O U P-1) / N C B L O K \bullet 1)\end{array}$ & $\overline{-}$ \\
\hline $\begin{array}{l}C W \\
C\end{array}$ & IrHIST=( (NGROUP- $) / N C B L O K+1)$ & - \\
\hline
\end{tabular}




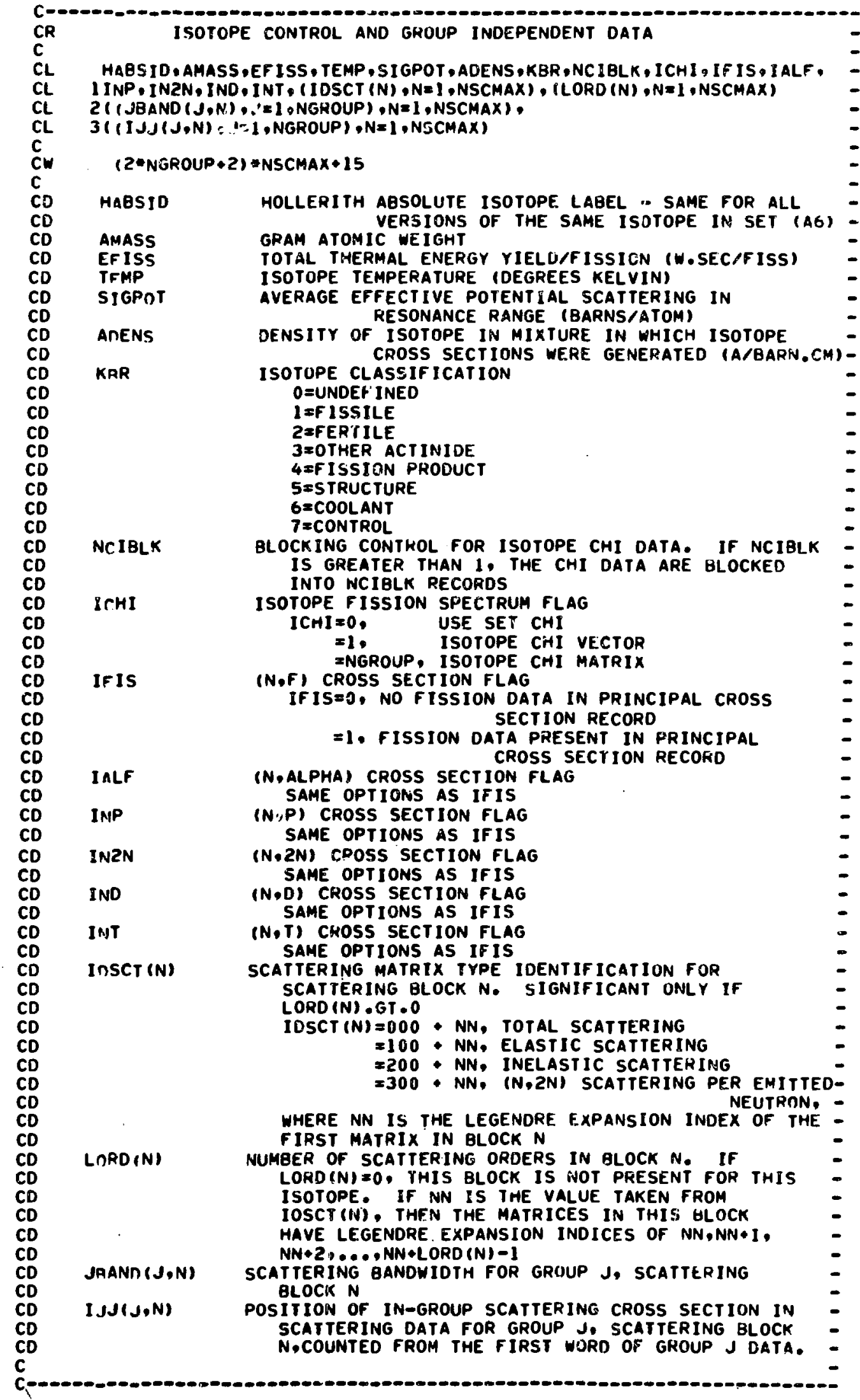




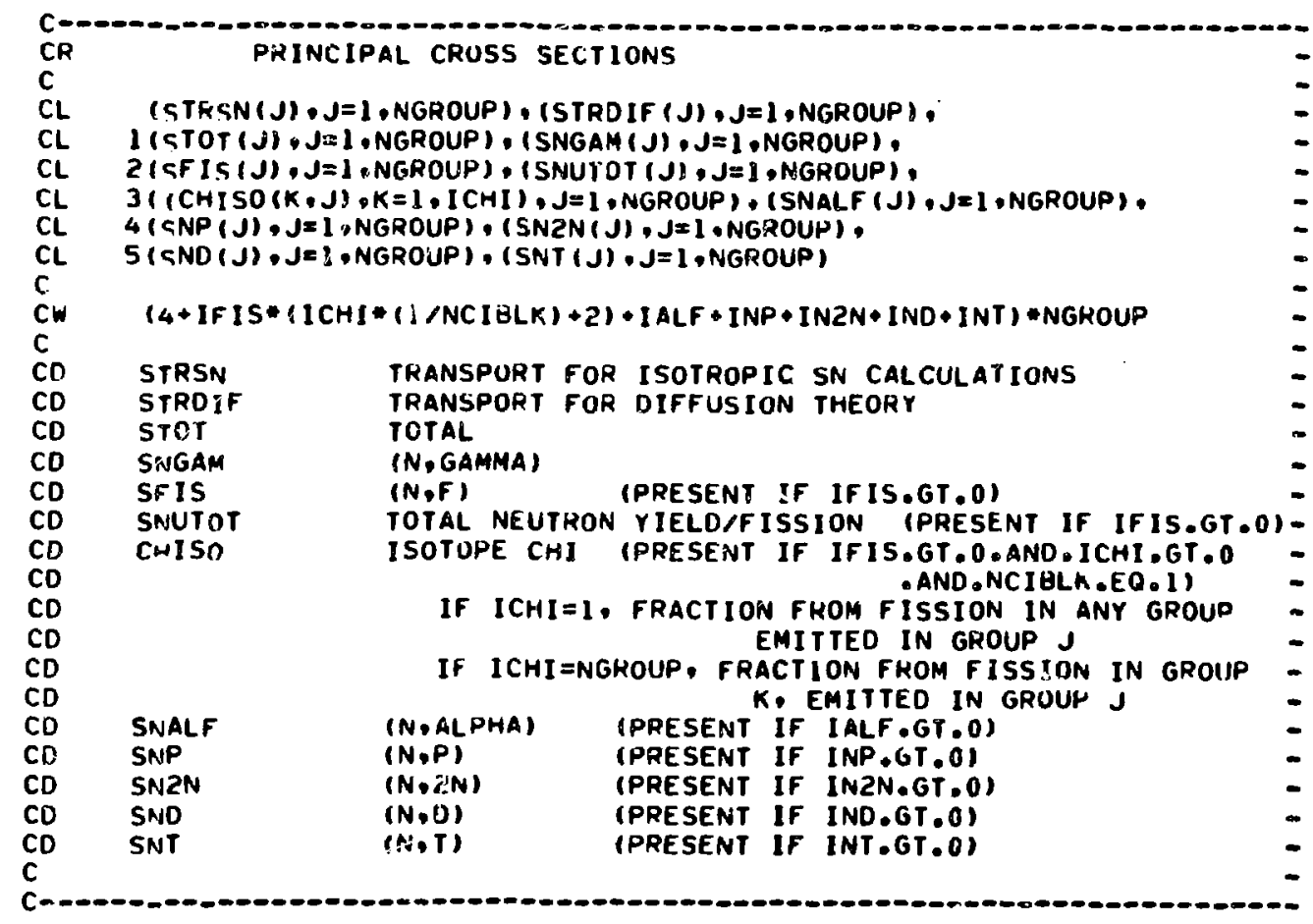

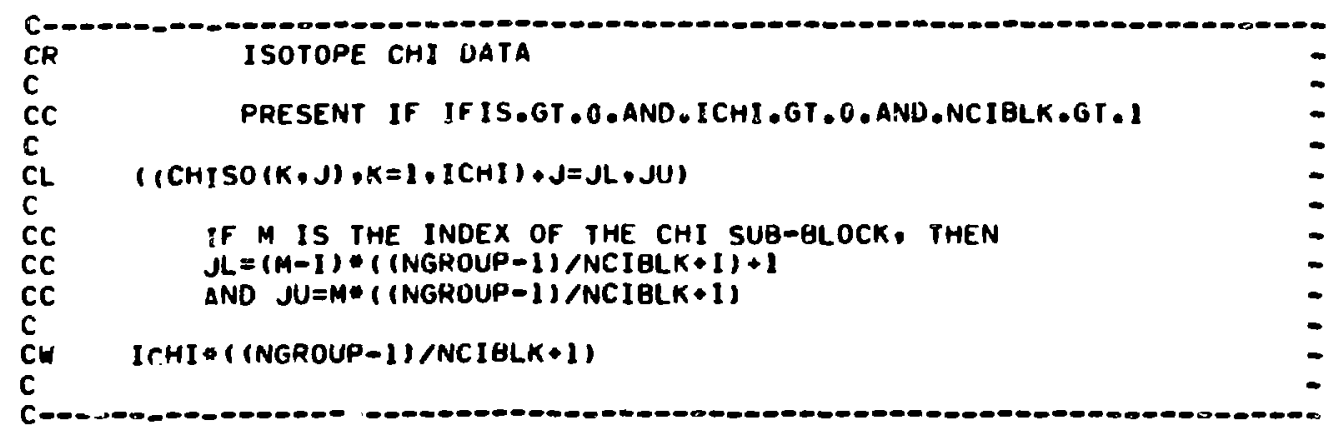

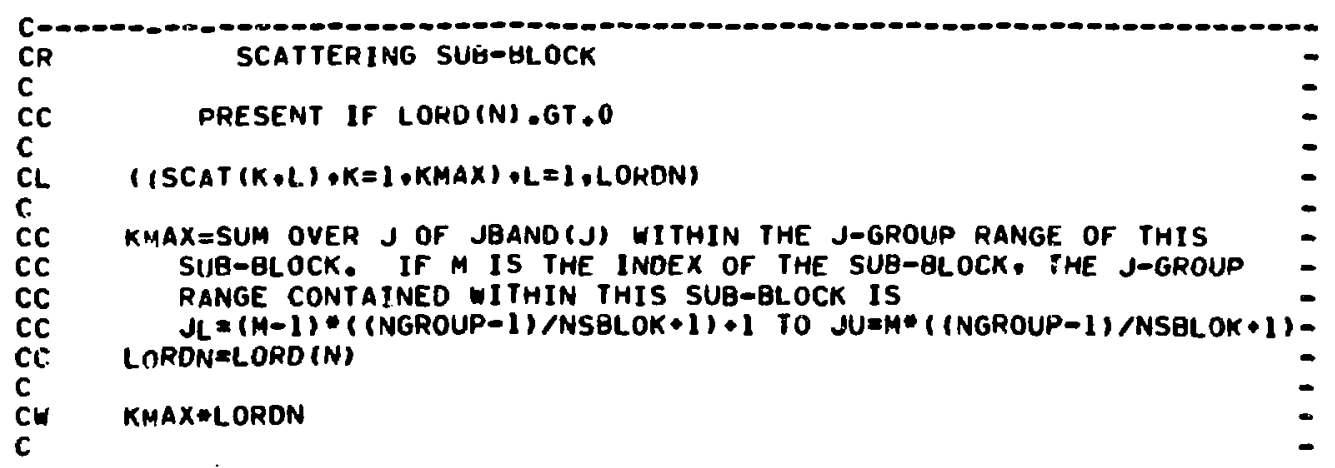




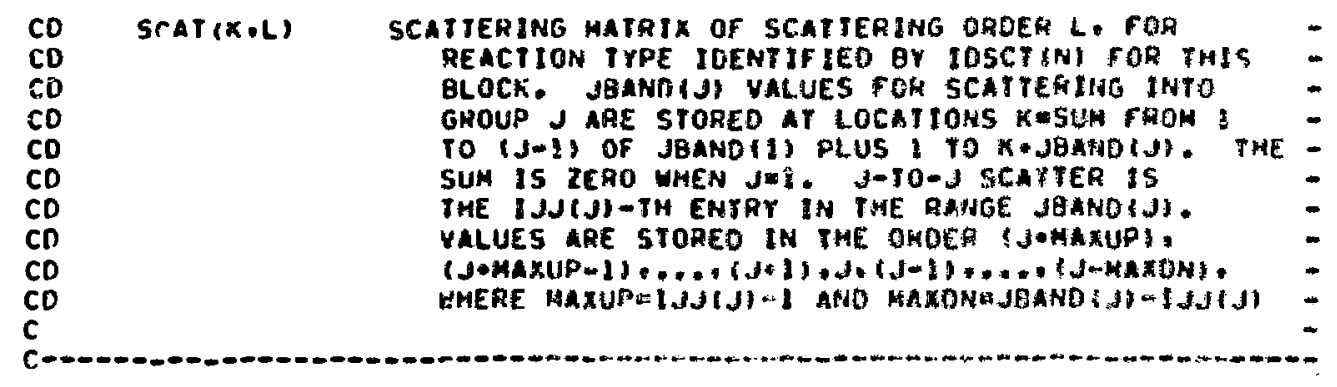

CEOF

\section{B. GRLPXS}

This flle conceins the sase deta to Isotxs. but ordered by energy group. It is expected that chis file will be produced frow Isotxs by conversion wodsle, then the ocher wodules will eccess GRURXS for further calculations.

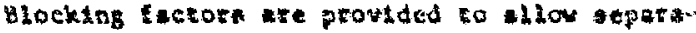
ton of the the lnto subther, ouch contalning all

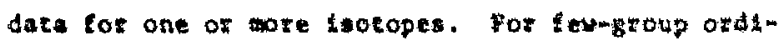

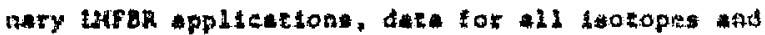
a single broup can be entered in thet recordo.

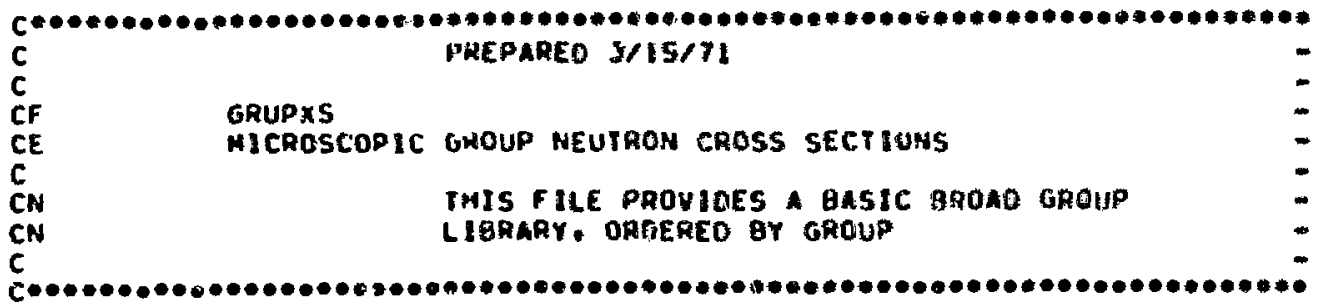

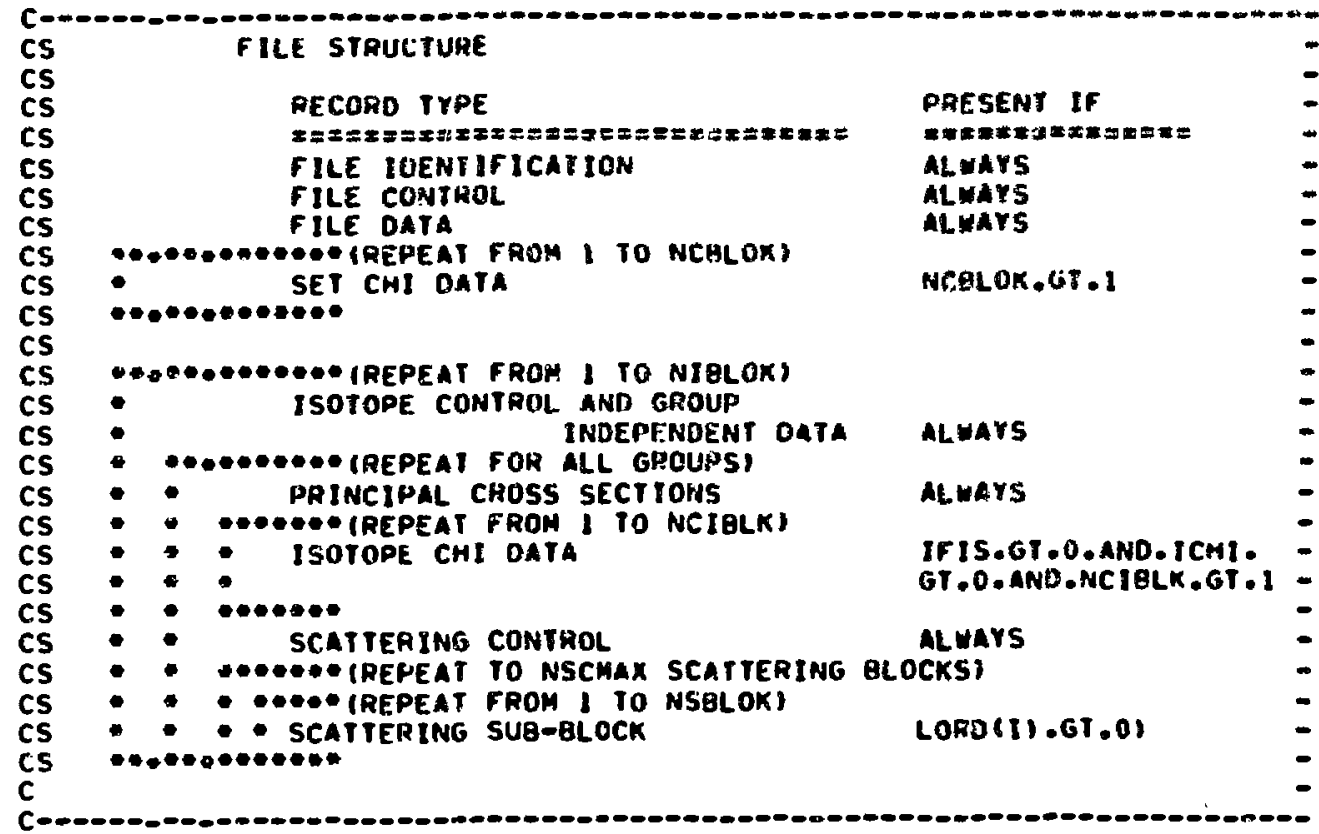




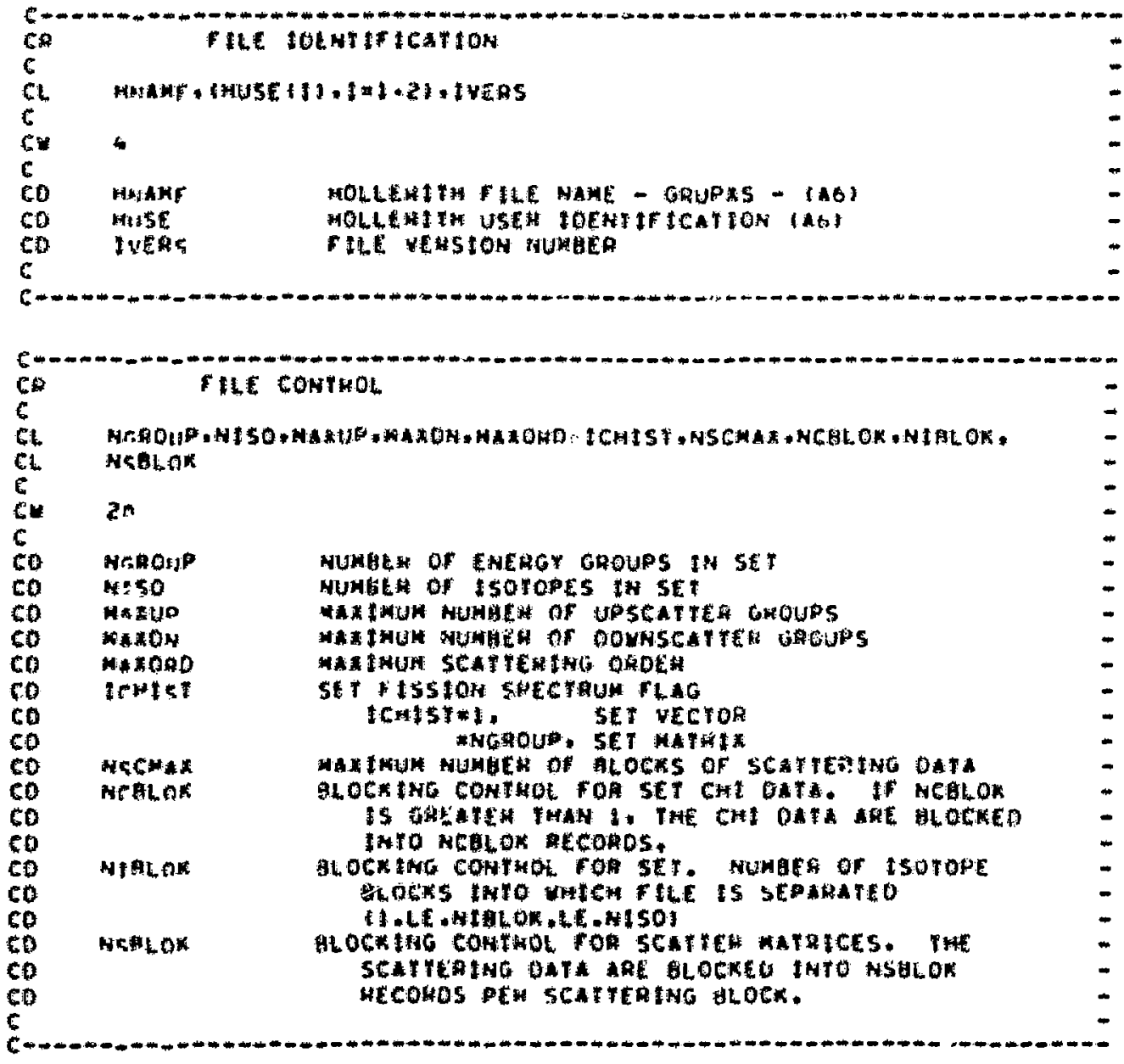

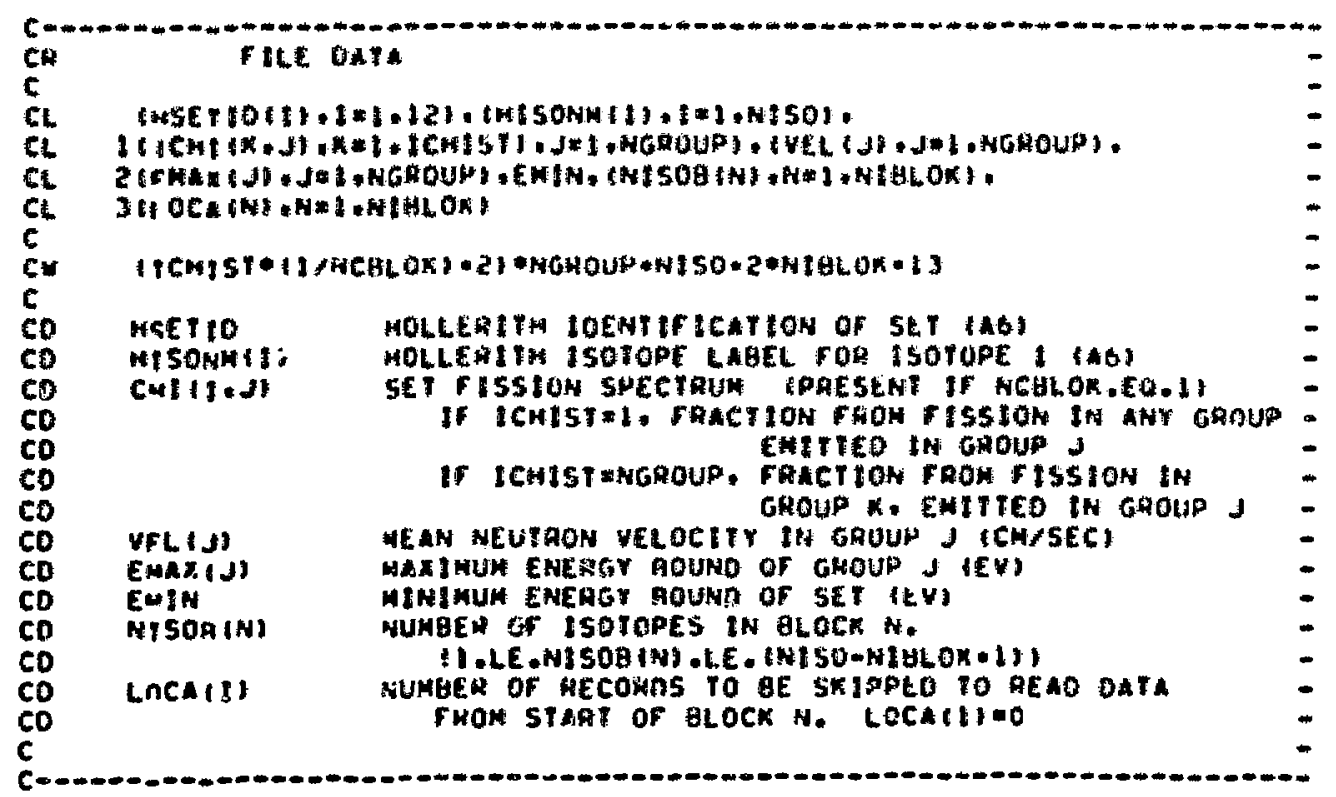




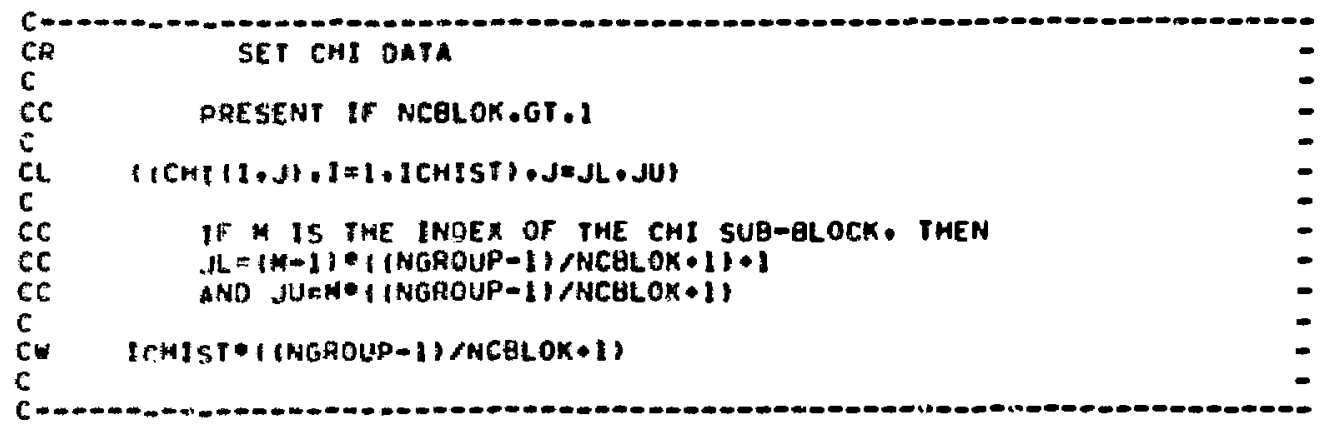

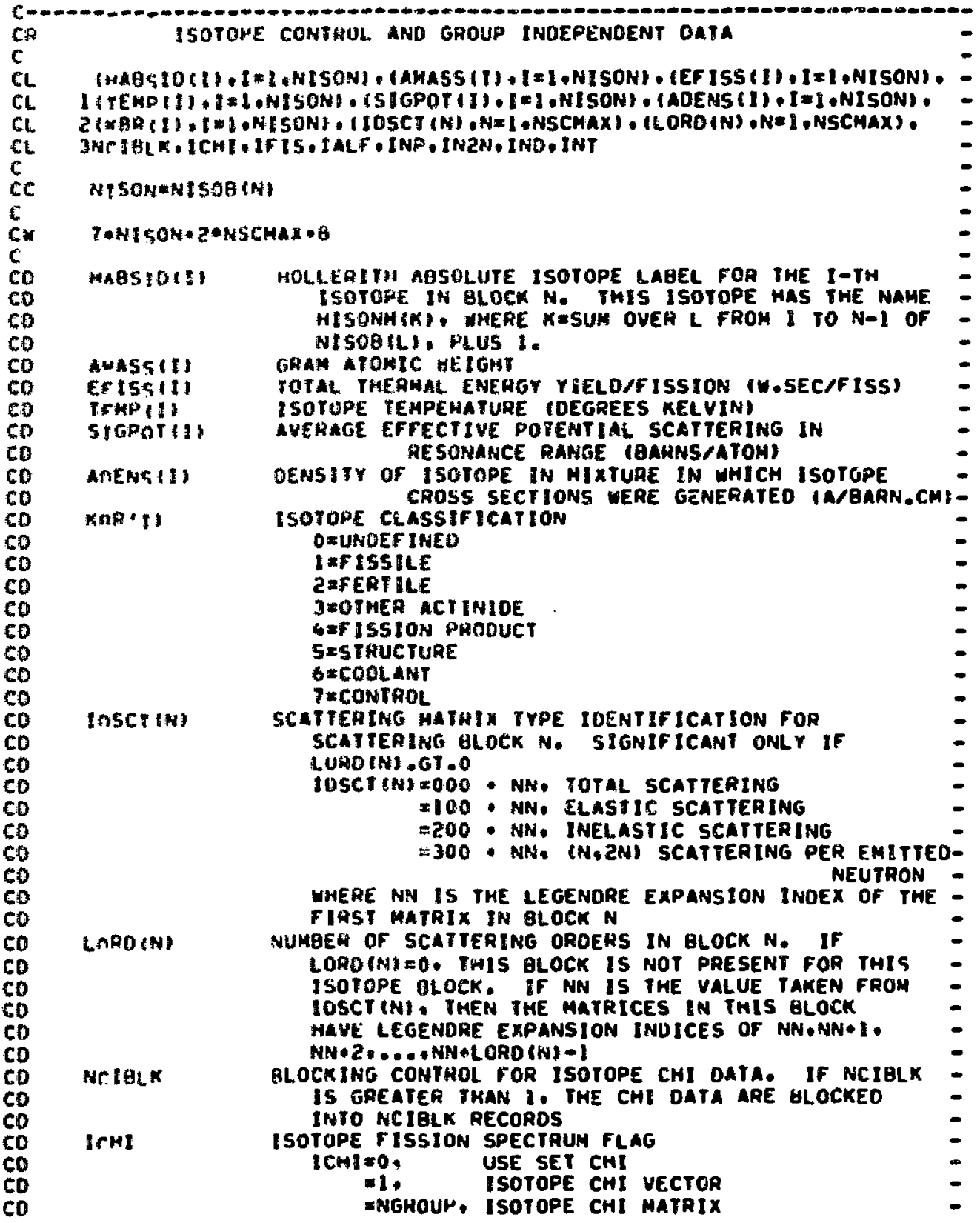




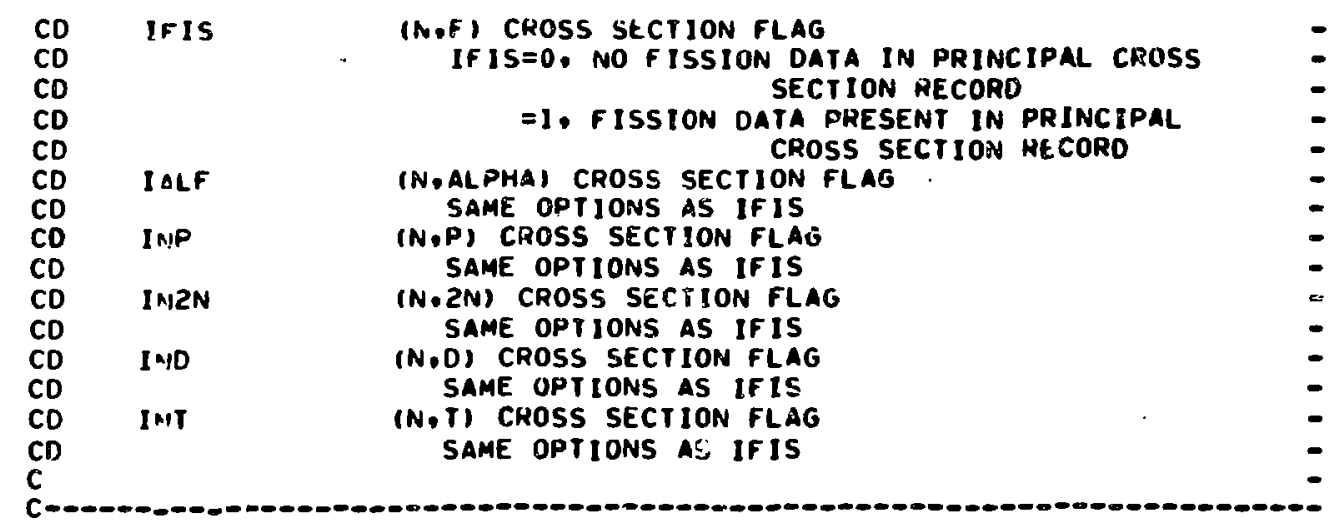

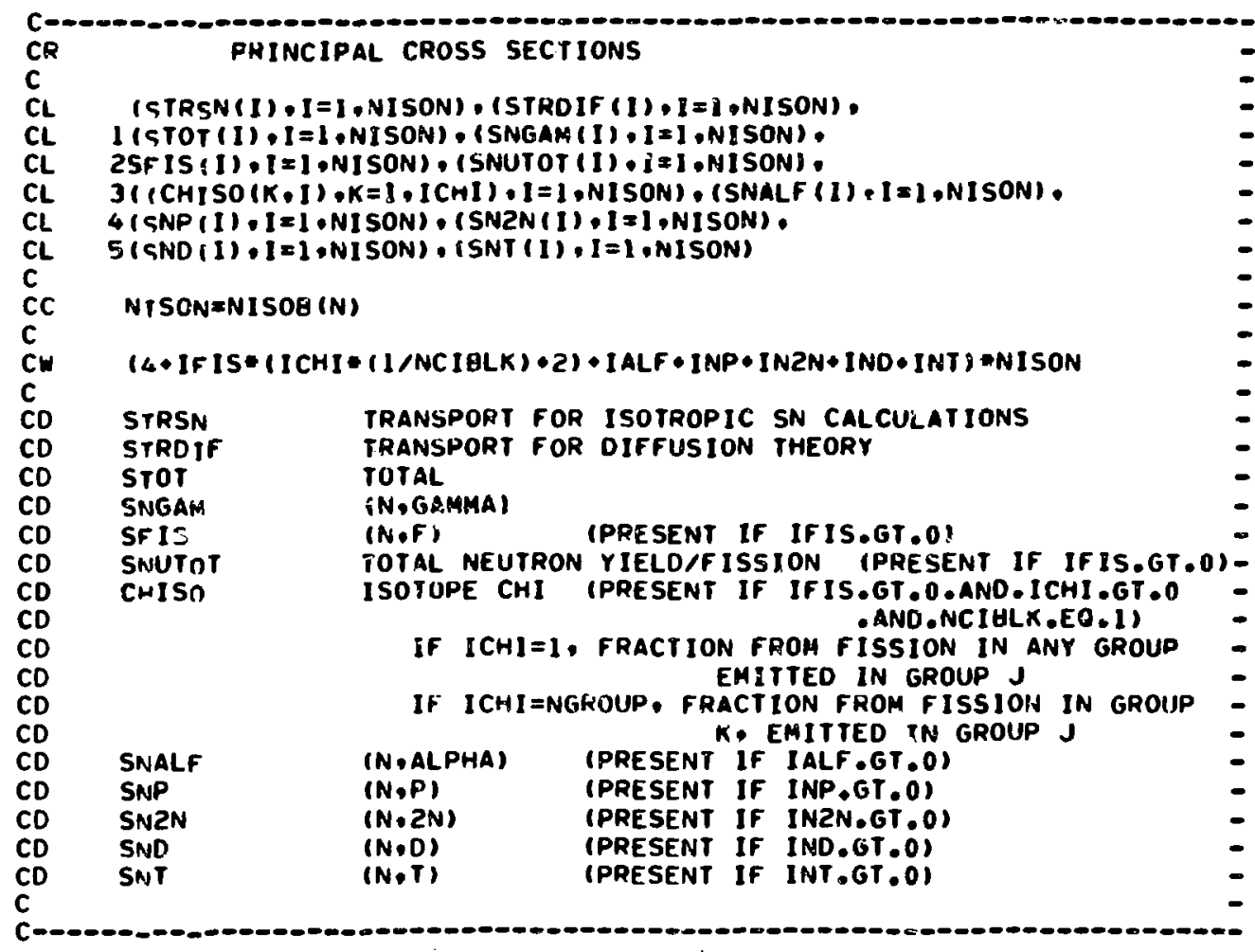

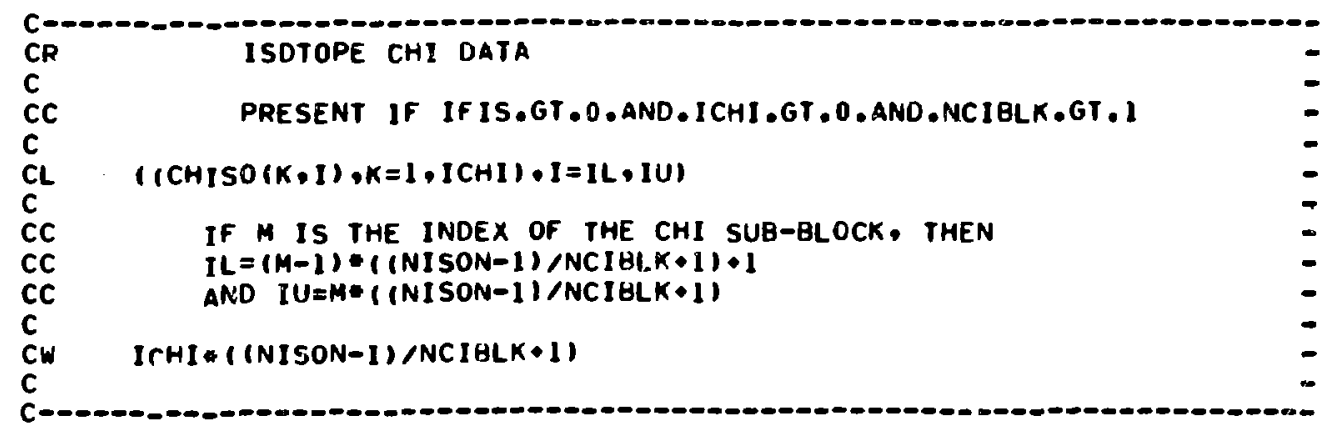



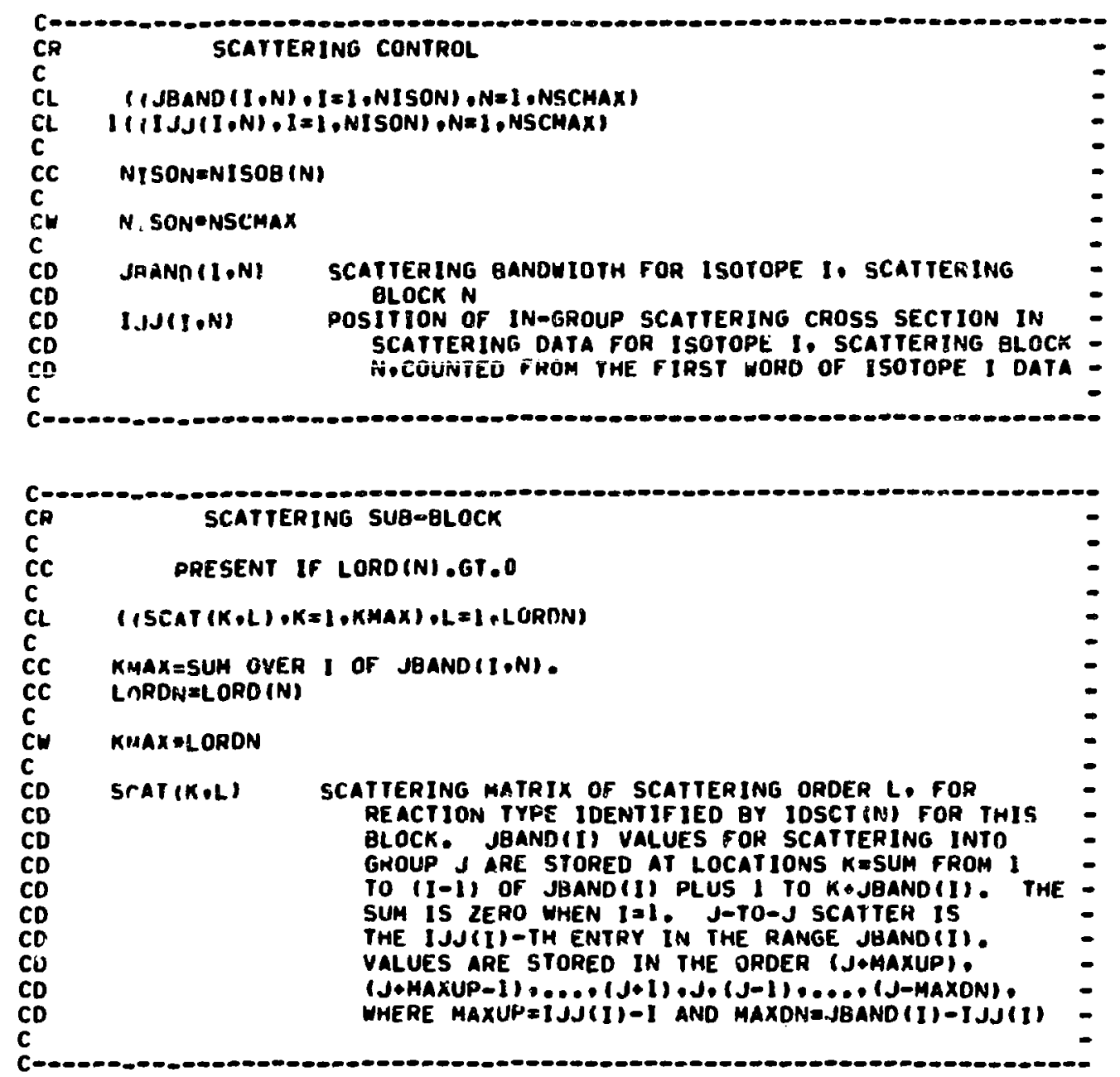

CEOF 


\section{c. DLAYXS}

This file provides the delayed neutron daca reduced to ouletgroup fora. The Individual daca blocks are related to crosg-aection flles in IsoTXS and Gabps by the absolute leotope 2abel. The set energy boundartes are included la this flle to provide a constagency check with flie isotxs (or GEUPX).

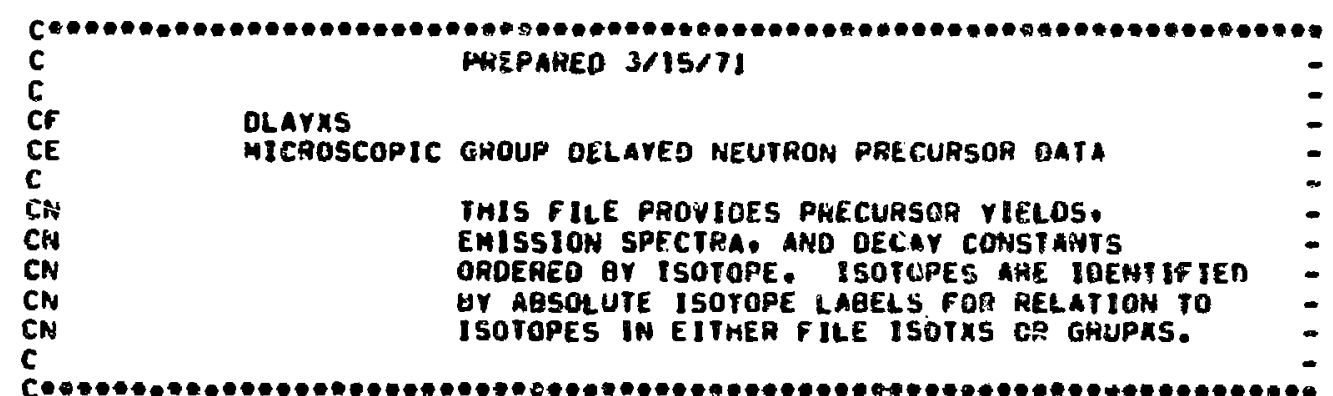

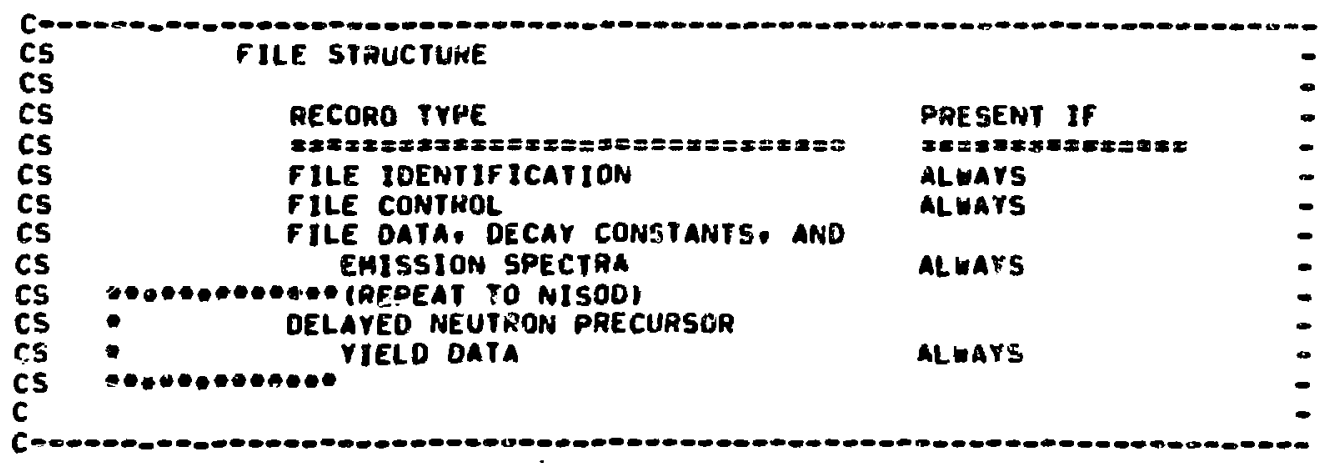

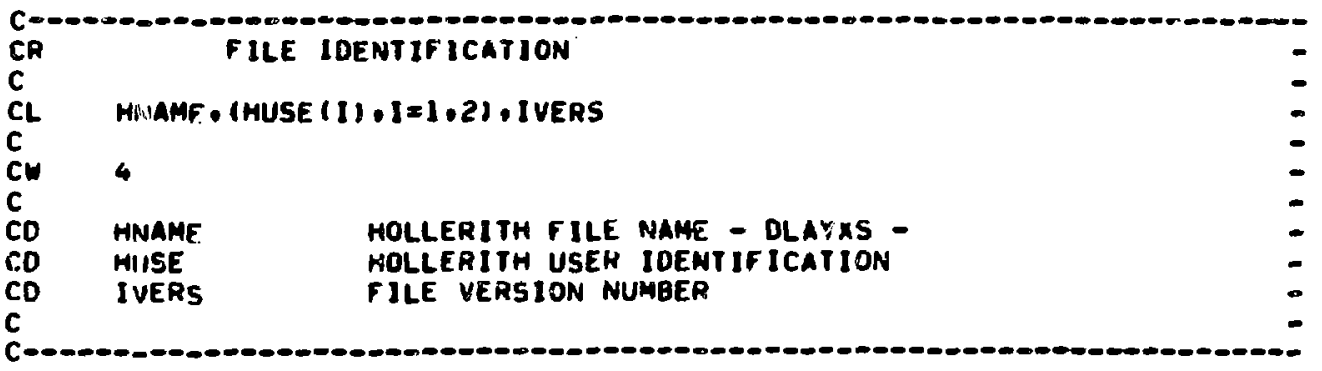

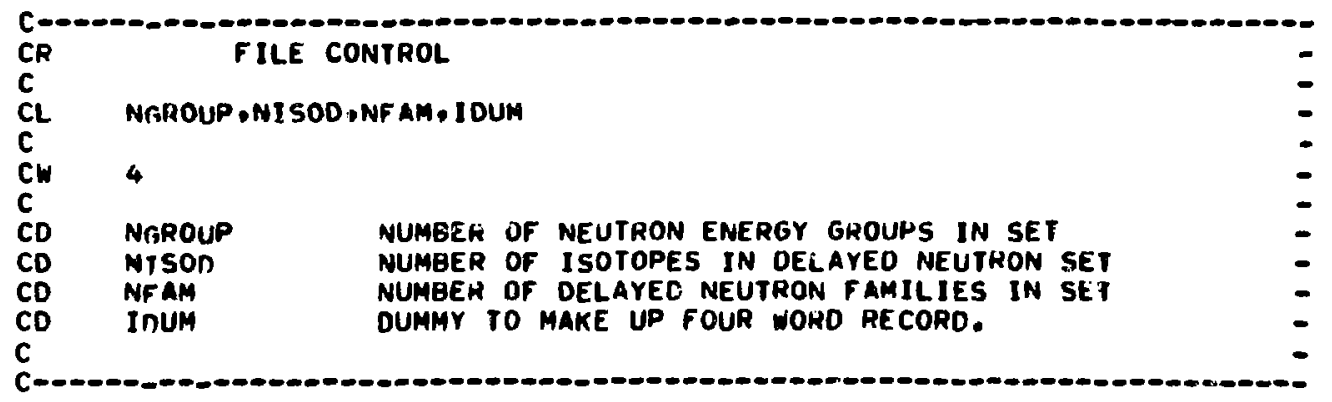



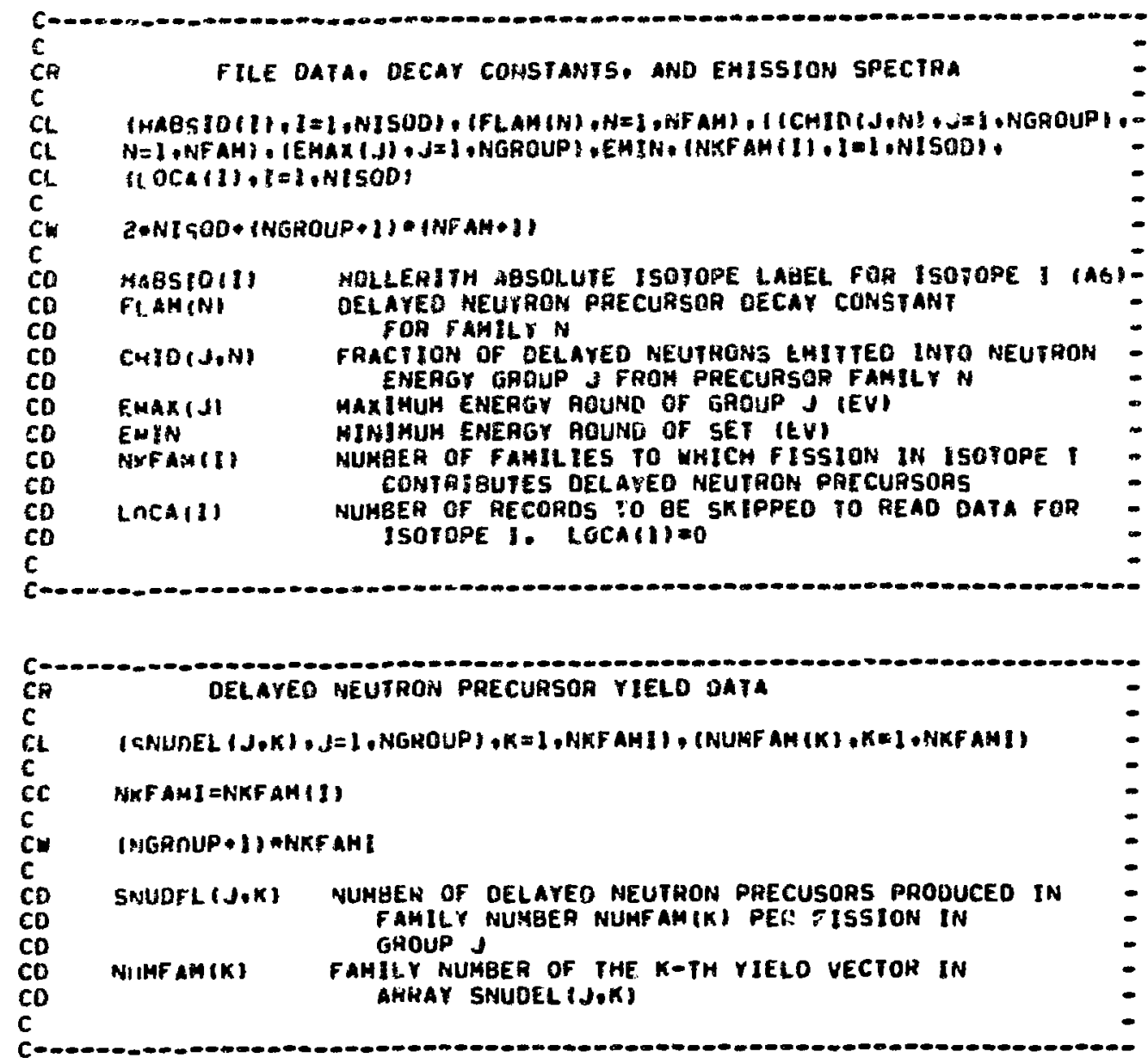

CEOF

\section{HRKOXS}

This file is required in conjunction with an ISOTXS (or GRUPXS) file when the Bondarenko selfshielding method is to be used. The set energy boundaries are included to provide a consistency check with the remaining cross--section data in file ISOTXS (or GRUPXS). The output of a processing code would be a self-shielded version of ISOTXS (or GRUPXS). Only those 1aotopes which have interpolation tables need be included in BRKOXS.

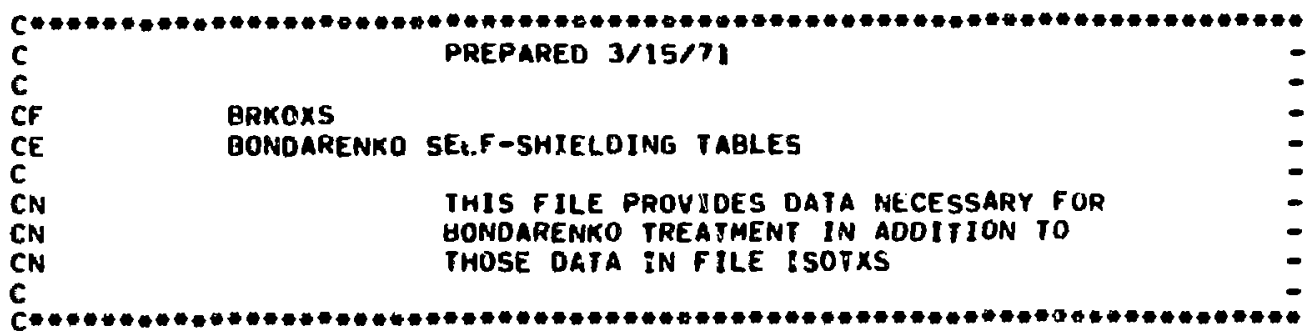



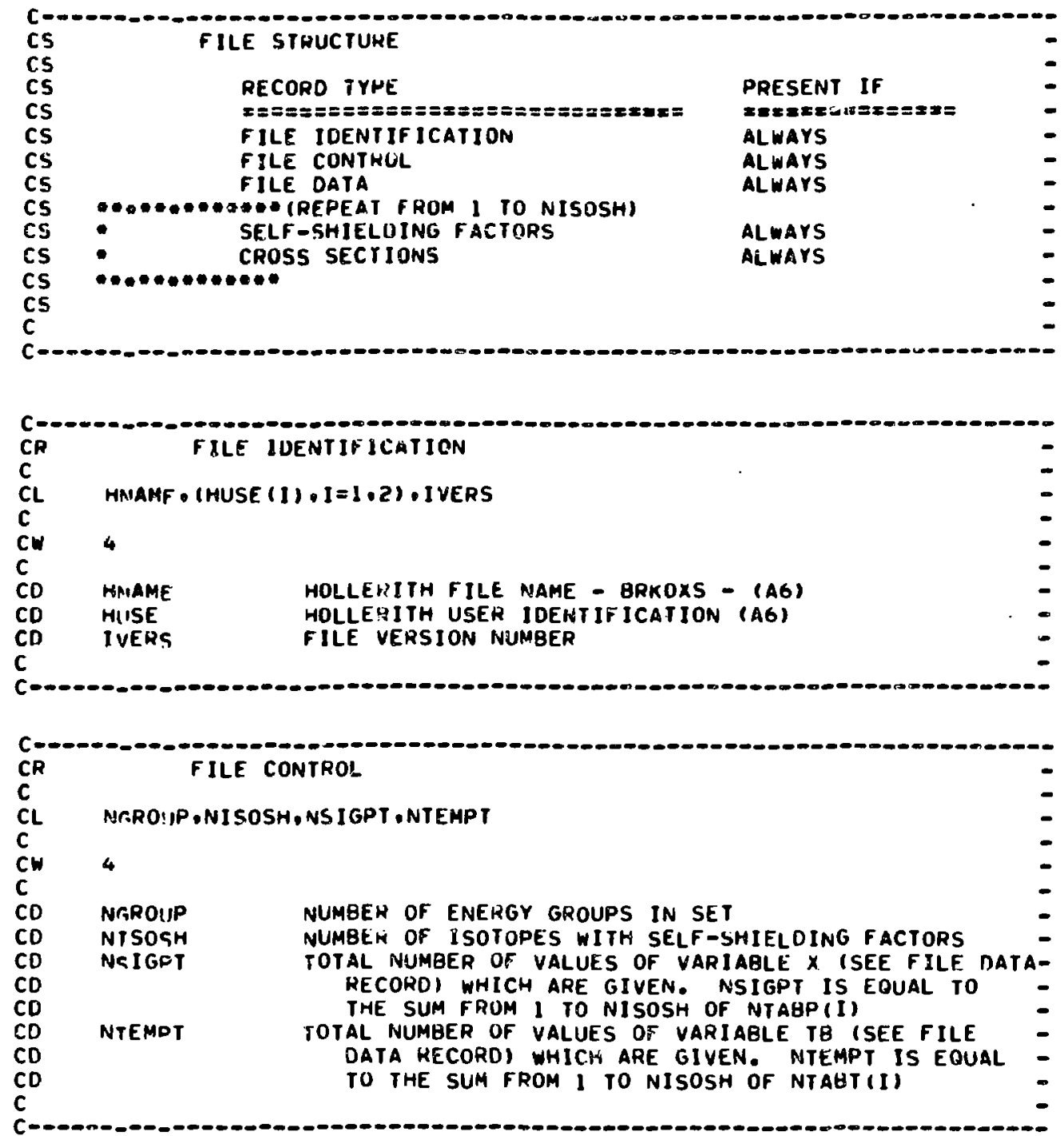

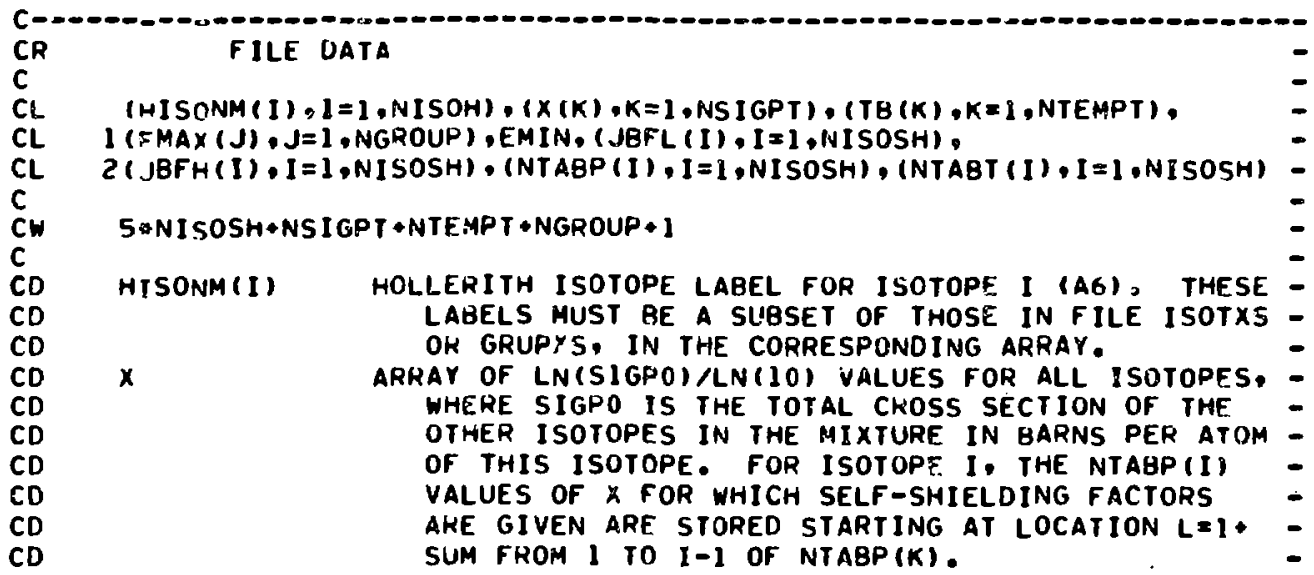




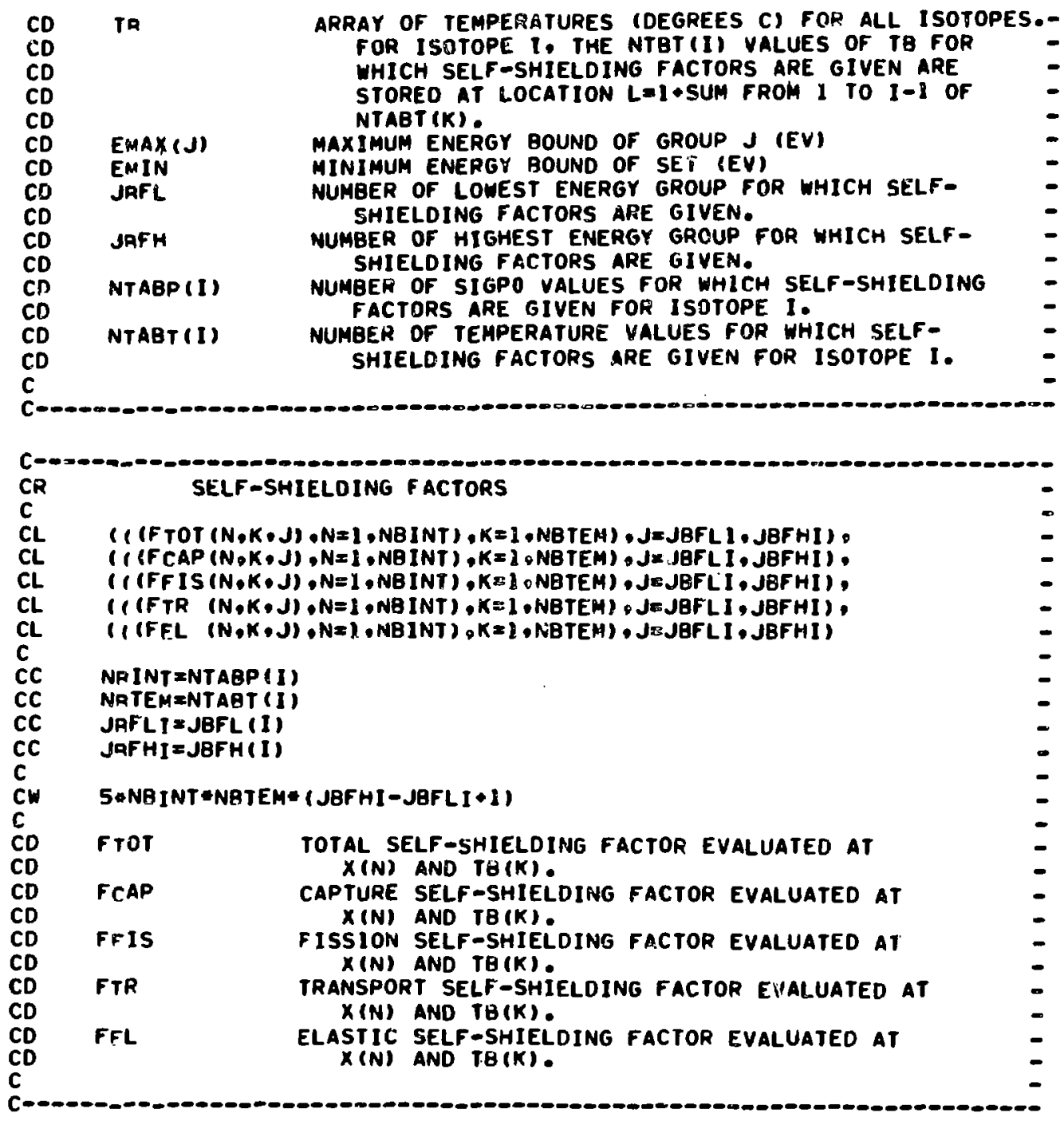

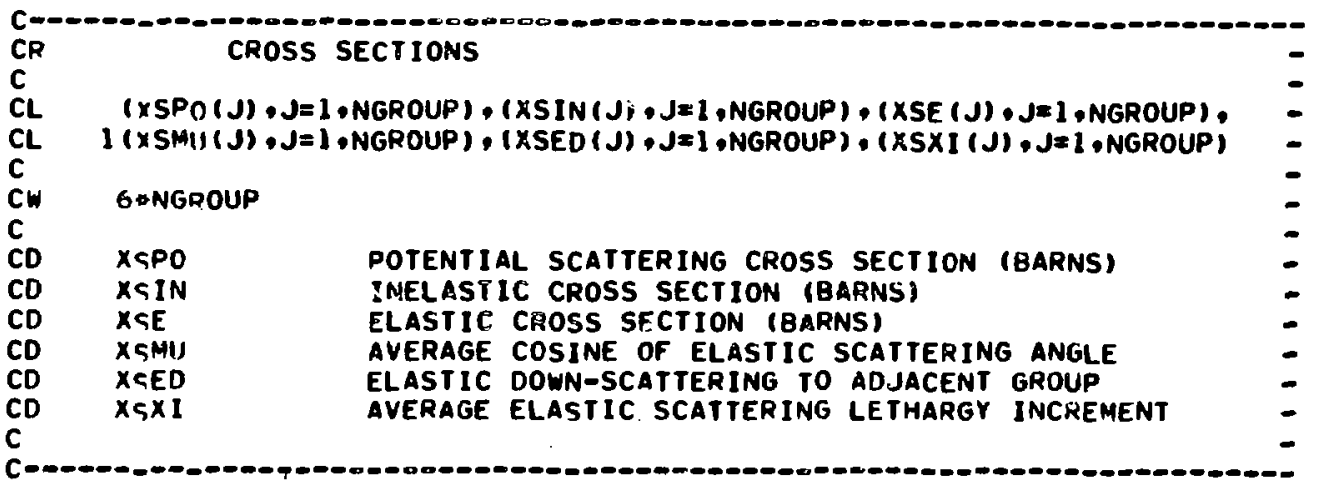

CEOF 


\section{E. GEODST}

This flle presente a geonetric dencription for - neutronice problew. Up ro three epece traverees ere given, orthogonal excapt in the caee of triagonal or hexagonal geometry. Boundery conditions are specifind at each end of each traverse, and 1ntervals are aselgned. A region number lo ascigned to each geosetric location contained within intervel boundartes, and a zone nubber 10 anspaed to each reglon. Thus, a zone conalste of one or wore reg1on, not necesear1ly adjecent, wh1le a region 18 ande up of one or sore discrate volues elesents, also not neceserily adjecent. (DIecrete voluse elemente contained within one region could heve Identicil volumee if deelred, but this 1o not a requitement of the file specification,)
The paranster ICOH Identifles a coordinete ayetem. A zero value 1o for a point (fundarentel mode), $1 \leq$ IGOA $\leq 5$ 1e one dimemelonal, $6 \leq$ ICOM $\leq 13$ 10 two dinenational, wh1le IGOM $\geq 14$ opectfiee e threo-dieanitional ogatem.

Rolatively gonerel boundary condition are allowed, excepting any which would define a noneigenvalue problex. Thase have been arranged to adait elople Interpratation in both the diffuolon and the discrate ordinatee representation of neutron transport.

The file has provieion for geometris bucklinge to reprecent orthogonal dinenelon not represented explicitly.

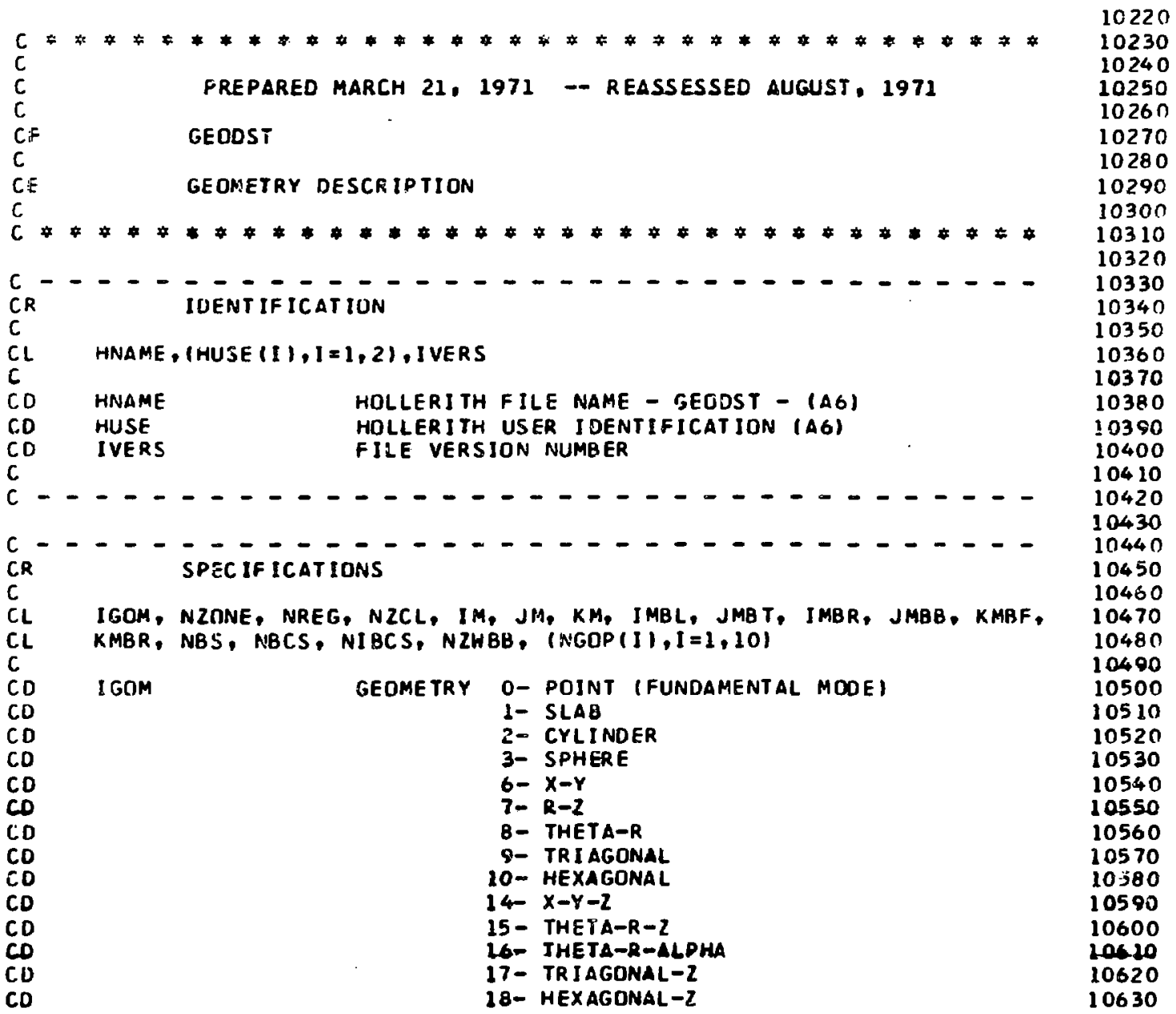




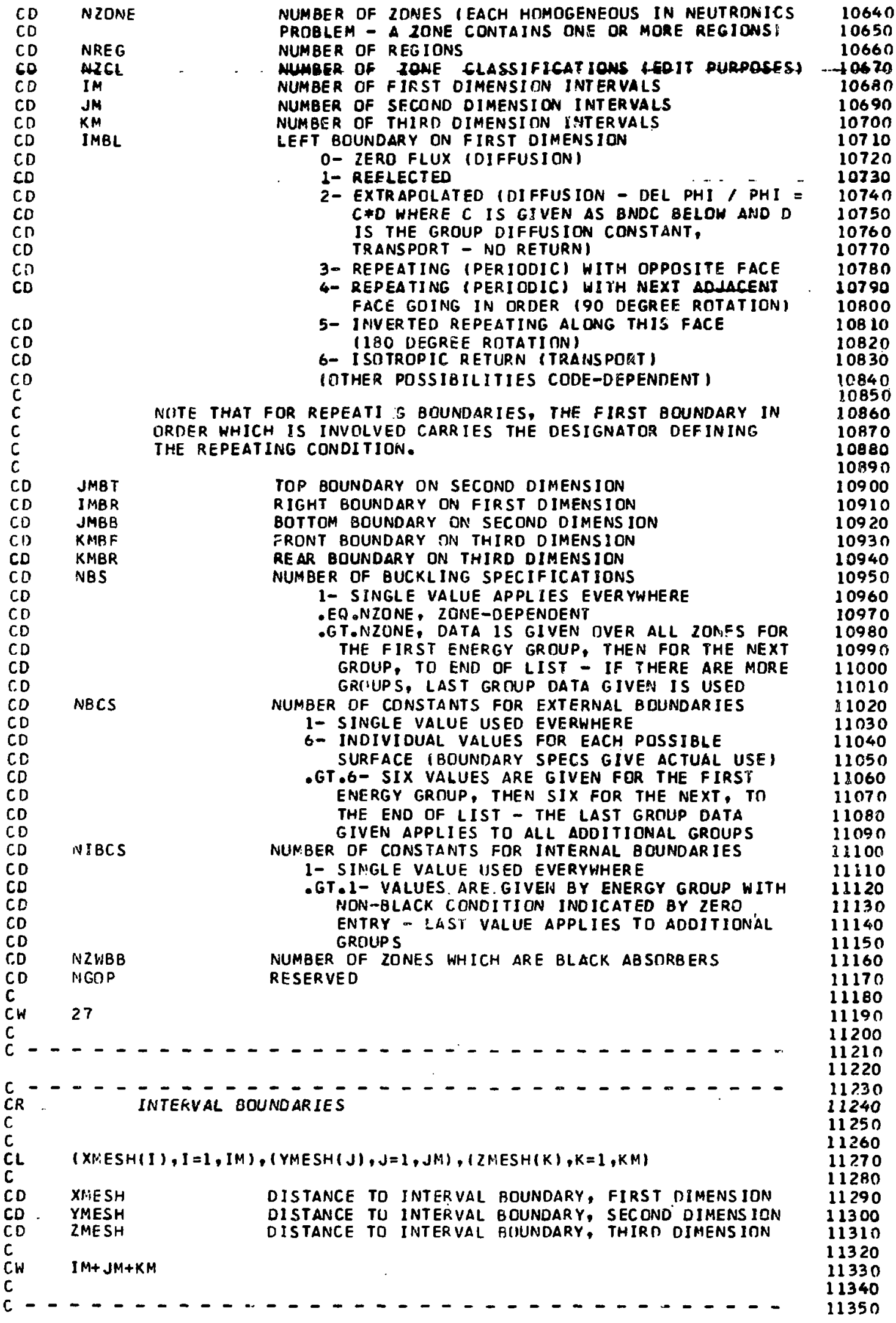




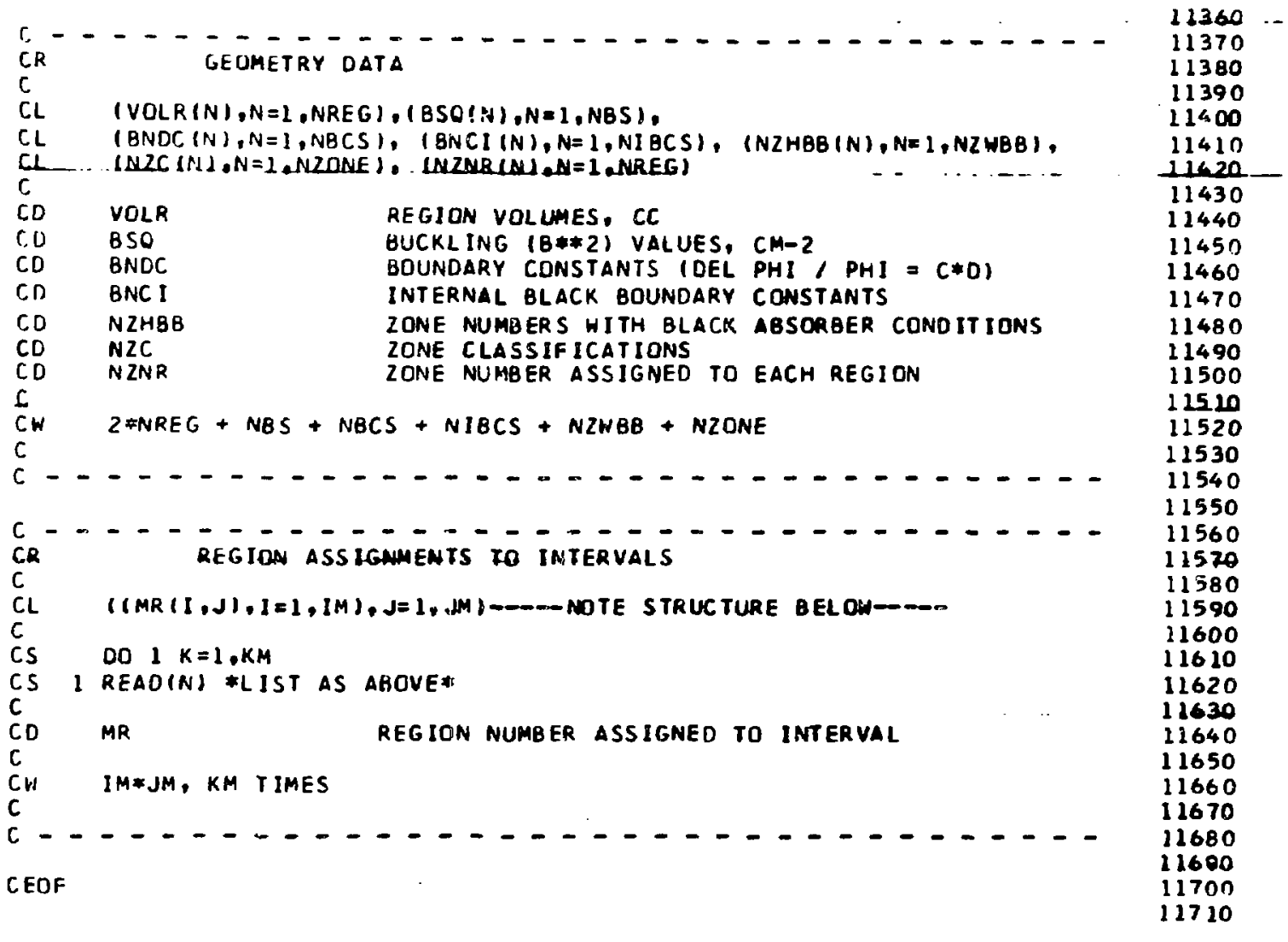

\section{F. NDXSRP}

Th1 file 18 a compromise butuen the verious techniquee now used to relate oucllde deneities with their geometric locatione and ancociated alcroscopic crose nections. Orse of the problen is date etorage. To facilitate the calculation of macroscoplc crose eection, we are providios neutron-energy-group-ordered f1le of atcroecoplc crose eactions. Thus, it 1e asauned that for the celculation of mecro date,

$$
\Sigma(x, 8)=\sum_{n \in t} \sigma_{n}(g) N_{n}(x)
$$

He can atore the auclide coucantretton, $M$, In core, the acrescoplc cxose enction, $\Sigma$, by region for one group and the neroscopic crose eectione, 0 , a necded. The ${ }^{\prime}$ 's wat be storad in core elones with $\Sigma$ for one group to avold cettous I/O problems. Tor fuel sanagenant proceasiog, it to aloo vary denirable to otore the W's. Mor if we und the athod of present $S_{n}$ codas to otore the ${ }^{\prime} \cdot$, , it would take three nubbere to glve a value of a muclide denaity. the nuclide Identification, and the secmetric location. To etore 10,000 auclide conceatration would take 30,000 pleced of inforent1or. For representative problene, there 1e conoldarable eymatry wich algoificantly reduce the 20,000 1dentifying minere with the echere chosen. We aleo find one lewel of wixing to be vary 1mportent. That 10, for fuel sangenent calculot1obe, we mad a cubdiviaton on the "zope" besle. It is the intent of this file to provide this eceond level of aubdiviaton in such a way that the neutronlce code blocke an recogoize and we $1 t$.

A proble ull require atcroecoplc croneeection data for each muclide treated (bON of these). Severel way be for the muclide but the date 10 walghted in a brosd-neutron-anergy aense on different aautron apactra. Iach auclide t:sented eaparately (WoN of them) Is asoigned a untqu neme (bMure) as well an aboolute raference (BNMiE). Having an ebsolute roferance greatly atrplifies the analyot'o 
prpblewe of providins date for both exposure and fuel anegenent calculations. In addstion, cartaln very auch naeded date to contelned in thio 111 , ouch as enarey por f10o1on, aconte weschee, and cleaelfication of the nuclsdas for both adt pur-

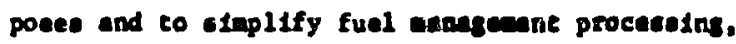
wuch of te frow the Isoms fils.

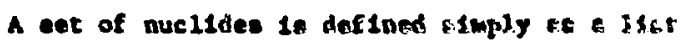
extracted from those contalned in a 11brcty of microscople crose section, the GRUPXs f1le. These would aorwally be those nuclldes wheh have a somwon location (at one or wo altea) in a reactor. Identifytn these ellow apprectable reduecion in the etorage requlred for locating auclidee and releting thetr cincentretions to alcroscople crope sections.
Muclido conianerations are eastgned to zonce d1reet1y, or to subsones which ake up zones. Each zone 10 costgnat a volua eraction uhich applies to thowe concantrations ansigned to it directy (with no eubeones, a unity volue fraction noraclly applien). Subtonct aceacteced with a zone whe up the rewlutut fiortion of sho sone. Mie nececeary

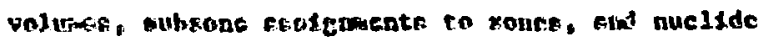
referencting date are provided. This referencing date le ecjurated from the ectusl auclido denolty dace to allow one set of date in thto file to be und wth rultiple note of the denateles. The denatiy deta, E1le zuxph, cannot be ucd without the inforestion in RDXSW.

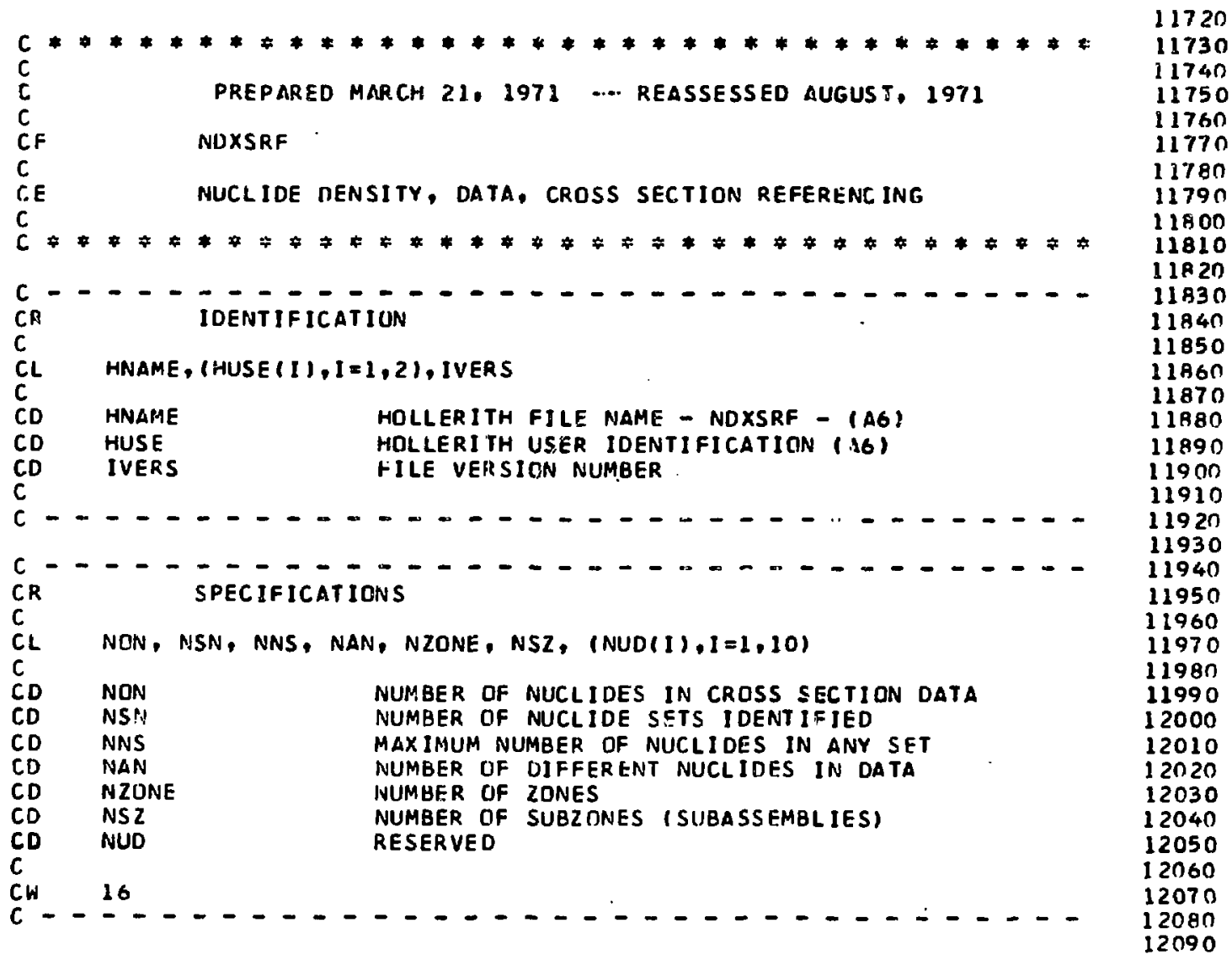




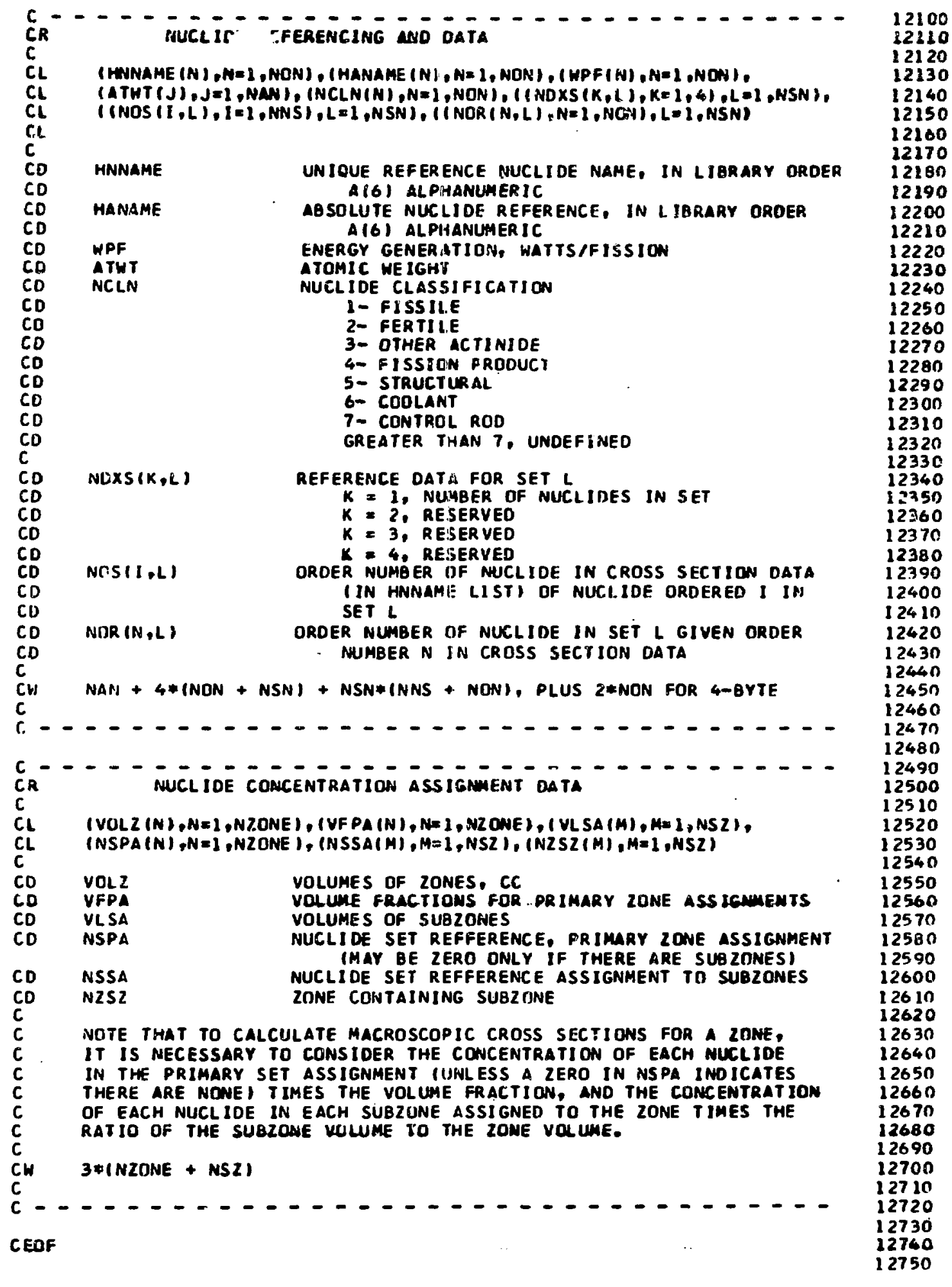




\section{2MATON}

This Ile contalne the auellds coscentration, atoule dansteles in ecowo/b-cs. The techalque of otorage aldocation that uas calected 10 a comprom aloe which

1. Milowe easy proceselns of ule1ple fllee of cate,

2. Porndte procenalos the date for quite daborate probleme in a recuanable anount of date -torege, and

3. Provides flexsblisty decend noceanary for the solculetion which 110 ahad.

The exrsy of atomle danotetos contalns the aselgnsente directy to zoneo followad by the oulfonte to oubzonse, whare e eubzone to a part of a sone. Givan the corzeopondence between aubones and zoned, a well so the relationahip between nuclldo dens1-

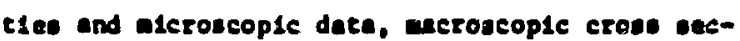
tione are calculated by tho aquation

$$
\begin{aligned}
& \Sigma_{x}(s, c)-f_{p}(x) \sum_{n \in X} N_{n}(x) \sigma_{x, n}(s)
\end{aligned}
$$

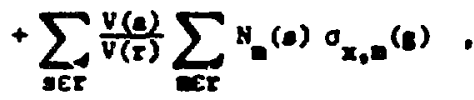

whore

$$
\begin{aligned}
& I_{x}(x, t) \text { rofors to crose-section typo } x \text { at 10- } \\
& \text { cet10D I 10 untey group is. } \\
& f(x) \text { is the volum eraction of the prianty } \\
& \text { andronones. }
\end{aligned}
$$

It 10 necunery to solete a to $\mathrm{H}$, unlag reforence dete of f1le HDXsir. Glven the nuclide order $N$ in che denatity array ADEN for sone J, L = MSPA(J) 10 the set roforence, and $M-\operatorname{MOS}(H, L)$ is the addreve ox ordering in the wete of crose-section dete, conpletsa the relationship. Sintloriy, for a nucllo'e order $\mathrm{n}^{1}$ in a cubsone $\mathrm{J}^{1}, \mathrm{~L}^{2}-\operatorname{uss}\left(\mathrm{J}^{2}\right)$ is the aet raferunce, and $\mathrm{x}^{1}-\operatorname{mos}\left(\mathrm{n}^{1}, \mathrm{~L}^{1}\right)$ is the stireos or ordarlay in the sote of crow-section date. The

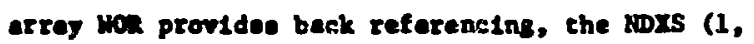
set aumber) to nubber of nuclidee in a eot, and M2Sz relates wbsonos with sones. Hote that nuclides In owbones of a sope wy or wa not wee the cese croon enctions. Thie providee conplete flexib1lity.

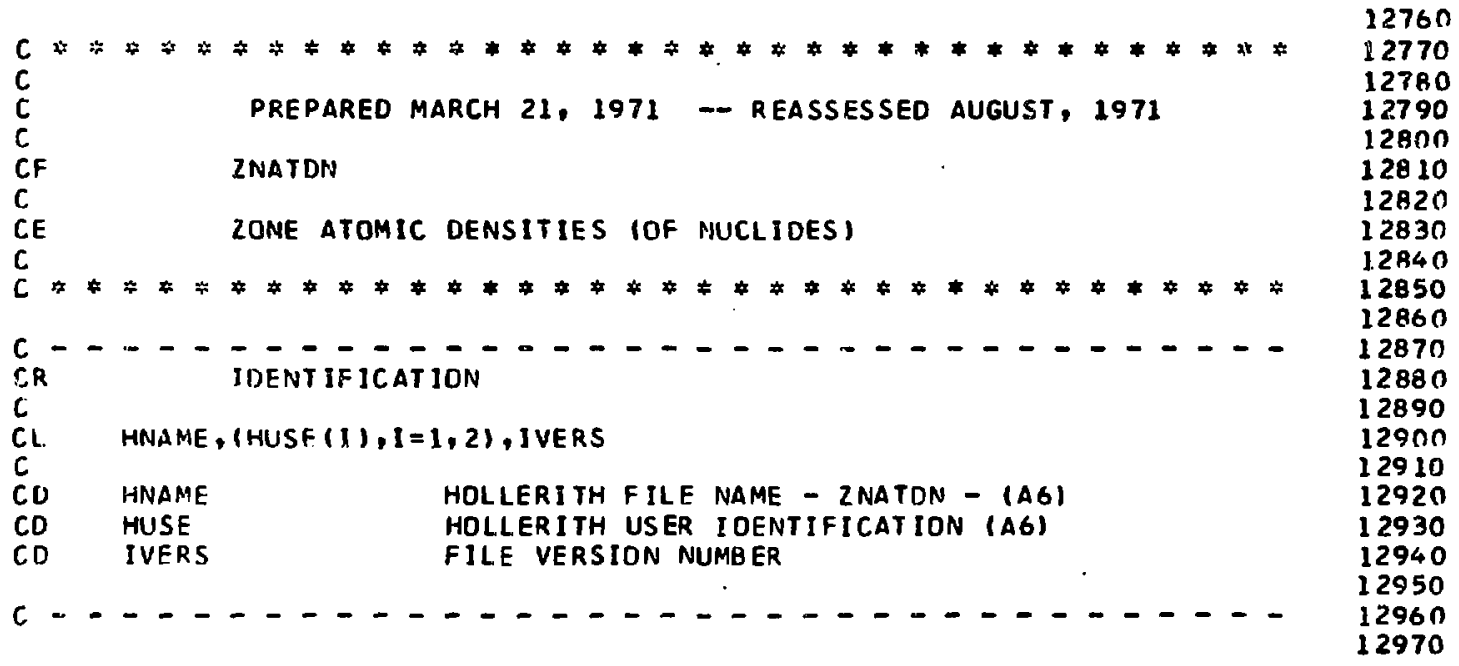




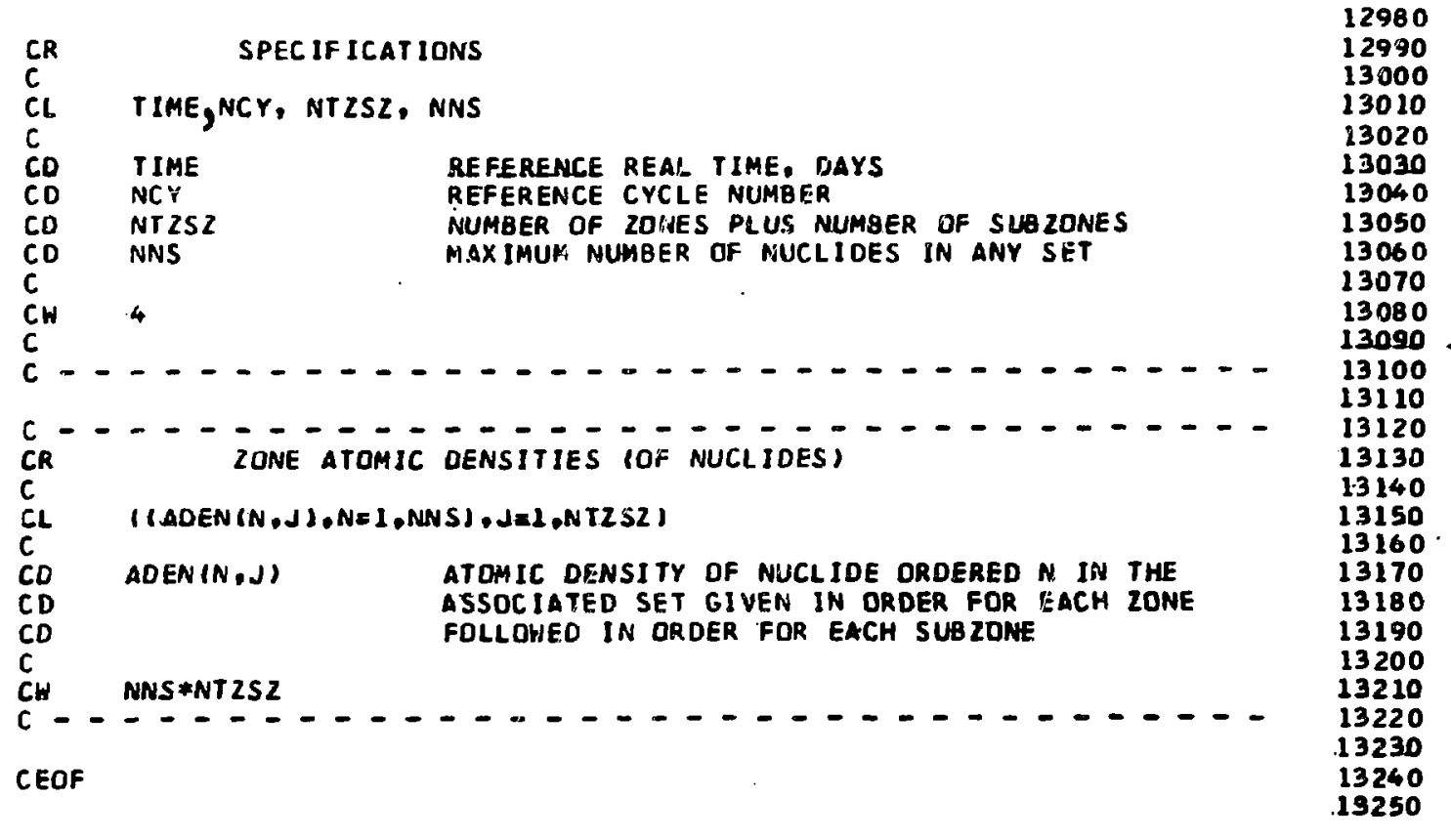

\section{H. SENGCH}

This f110 to net up to prootde flexible criticality eearch epacification, Inatruction a to

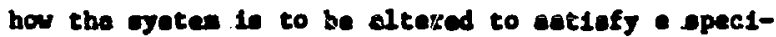
fled aultiplicetion fector. At the hasd of each block of dete for a particular ect of apectficat1ons. en integer 1dentifier is loceted for dtrect referencing by adrivar progran. An unpecifled number of blocks of this dete ay be pleced in one SPACE file, the whola ternlated wth a sogetive date eat Ideatifier uStrid.

The block of date for os earch epecification fitret contatins euch Information as the dealred ultiplication factor (whlab could be aubject to override by a driver) and the type of eaerch.
For the unal rectprocel veloctty (poeudo erce eaction) weoreh, proviatod 10 ande to une crovoeaction dste fron the Lbrary preponted as if it vere for a nuel1de.

For dimapodon cearch, provtelon 10 wede to wake relettve changes in "regtos thickoesees, where regitons are prewued to be contanous (ace the MR arcay In F110 GDDST) and parthape on a Elber scale than ere sopaw.

Conalderable flextbility ia allowed in the epaifications For nucllde concentrexton earohen, although the reatretton is Iponed that adjuttmace nay be ede only on sone concentretion or on eubzose concentrations. Huclide reforencing to through untque auclide nowes.

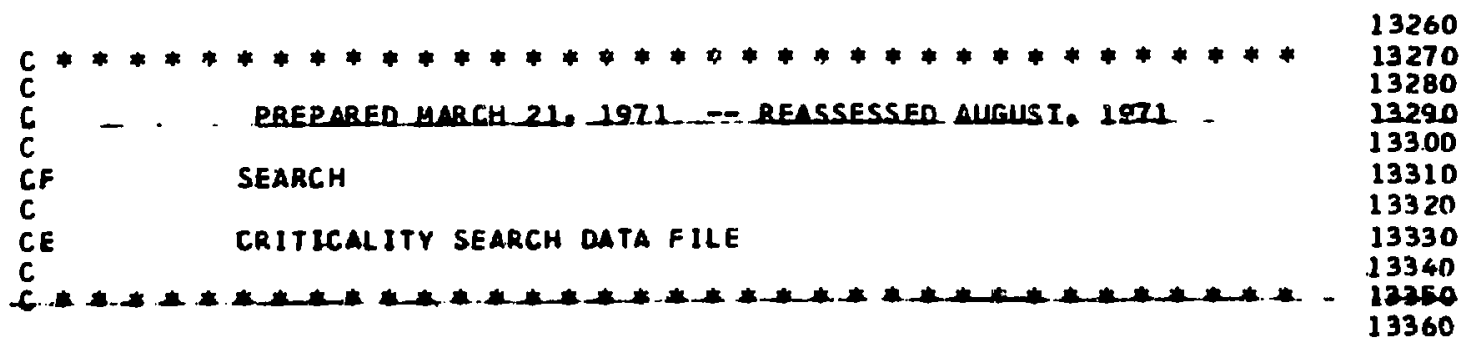




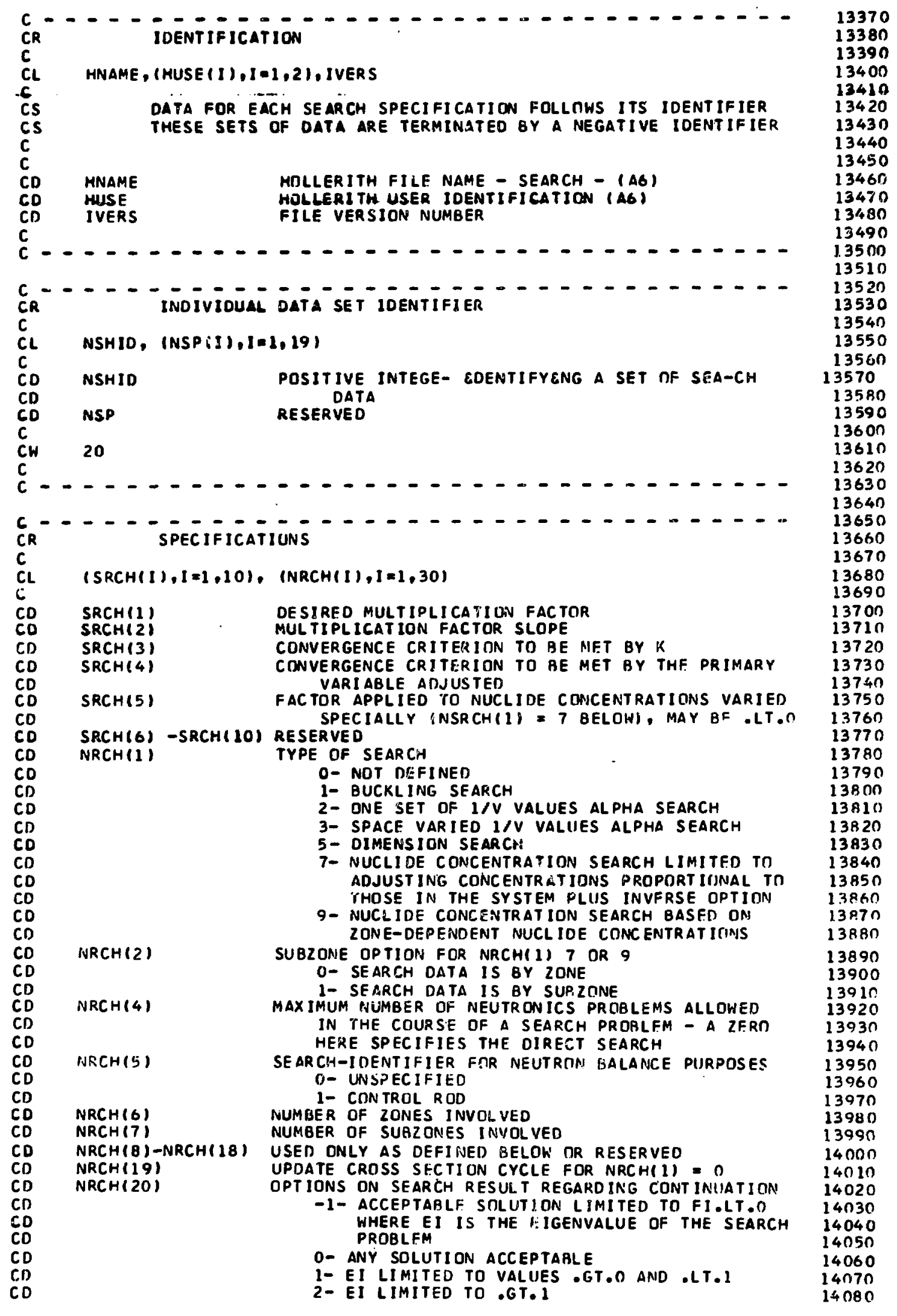




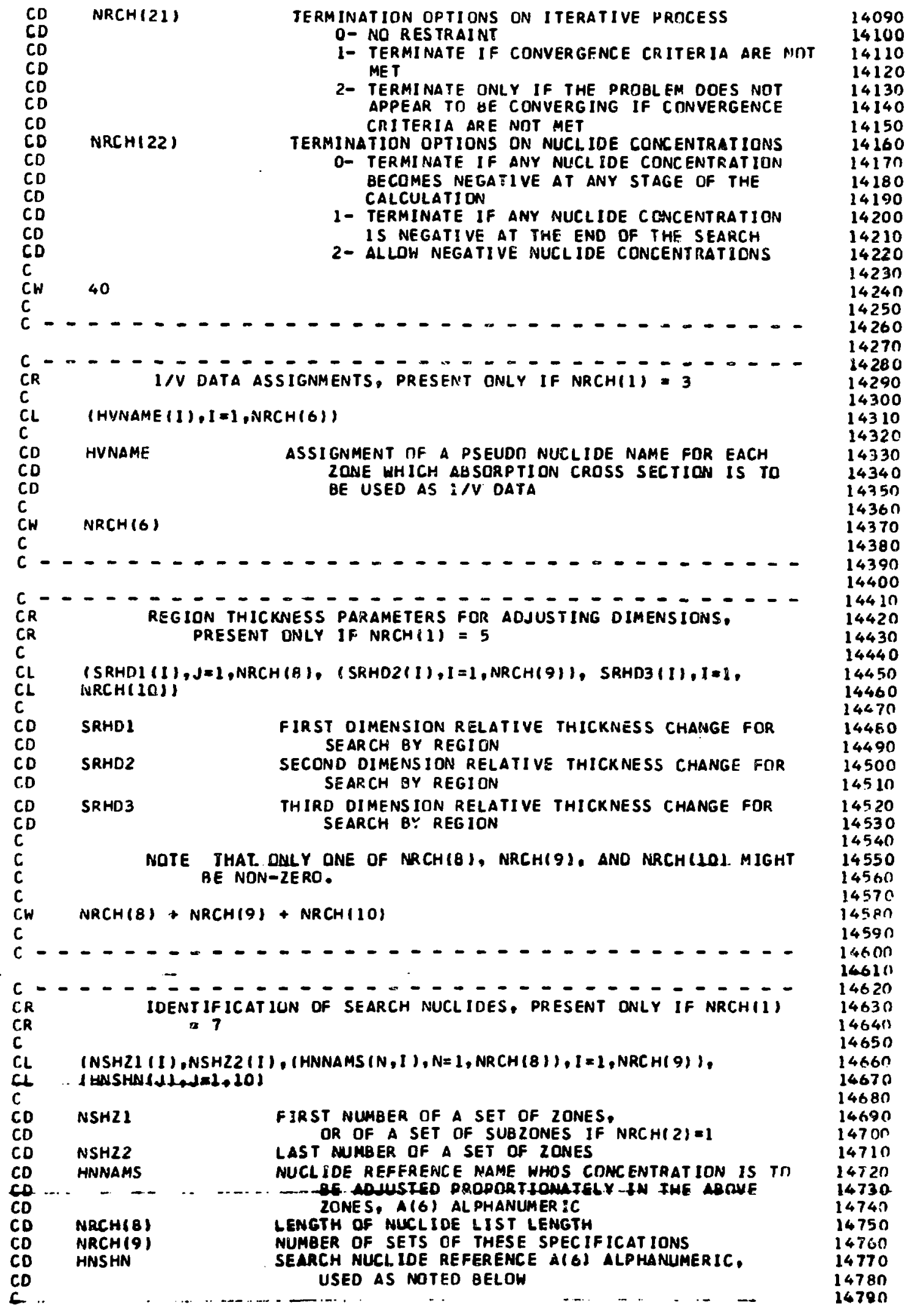




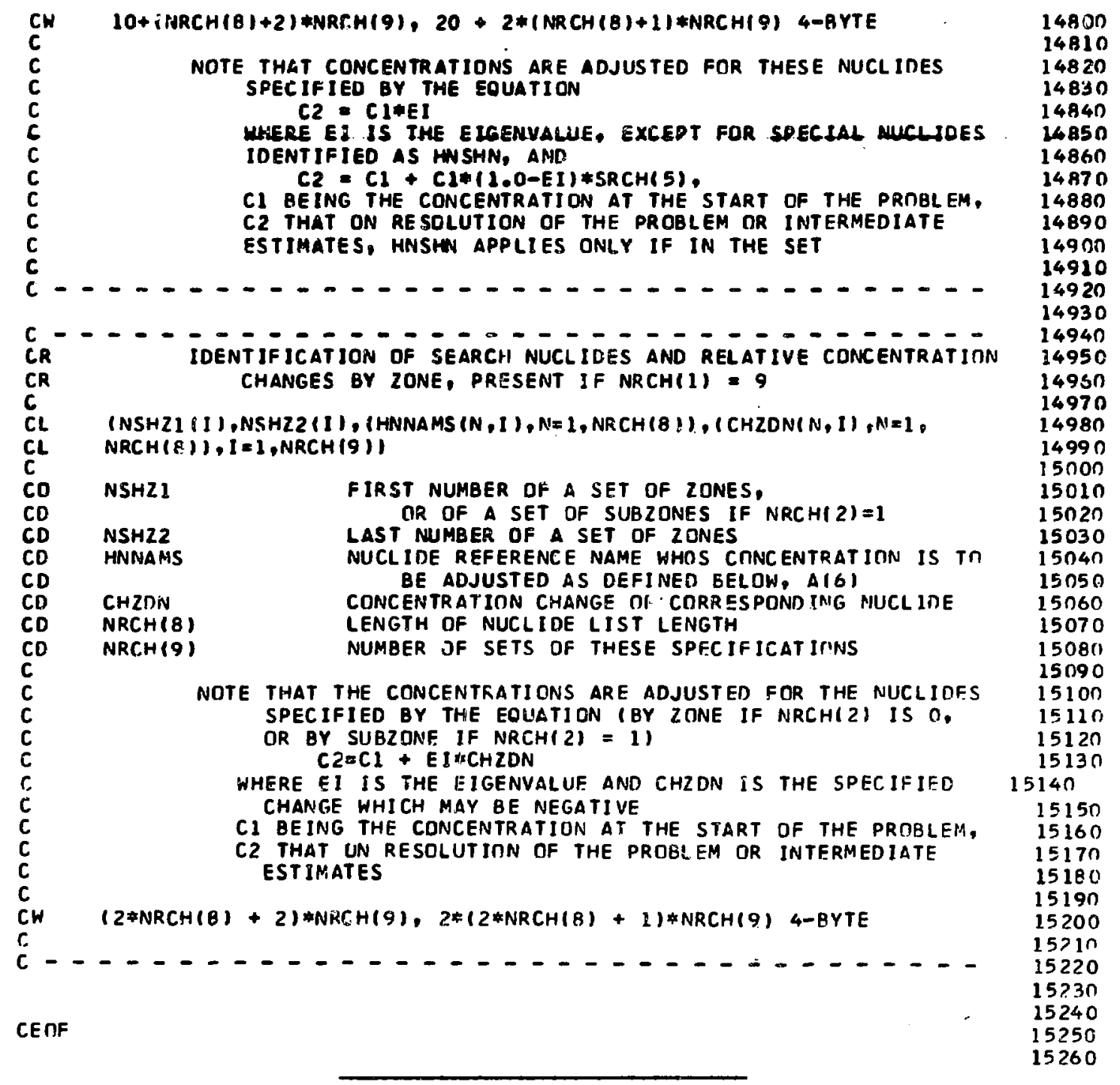

\section{Sircous}

It w11l be noted that two dumy 1teno are included in the Spacifications Record to fill out the liet to four words. In order for the search for the four worda in the Identification Record to be executabla, every racord in the f1les mut contain at lease four words.

The number of directions SDIR in this file will depend upon the $S_{n}$ order and the geonetry type. It way be obeerved that the algorithe ueed in determinInt NDIR 1a aomewhet arbitrary. For example, a different algorithm 1s used in the TwOTRAN sode than was used in earlier two-dimensional $S_{n}$ codes which leade to different values for NDIR. For this and other reasone, the datermination of NDIR 18 here taken to be a function of the input processor. The retrievel of directions and welghte from a library or from 1nput 1. also assumed to be an input processor function. 

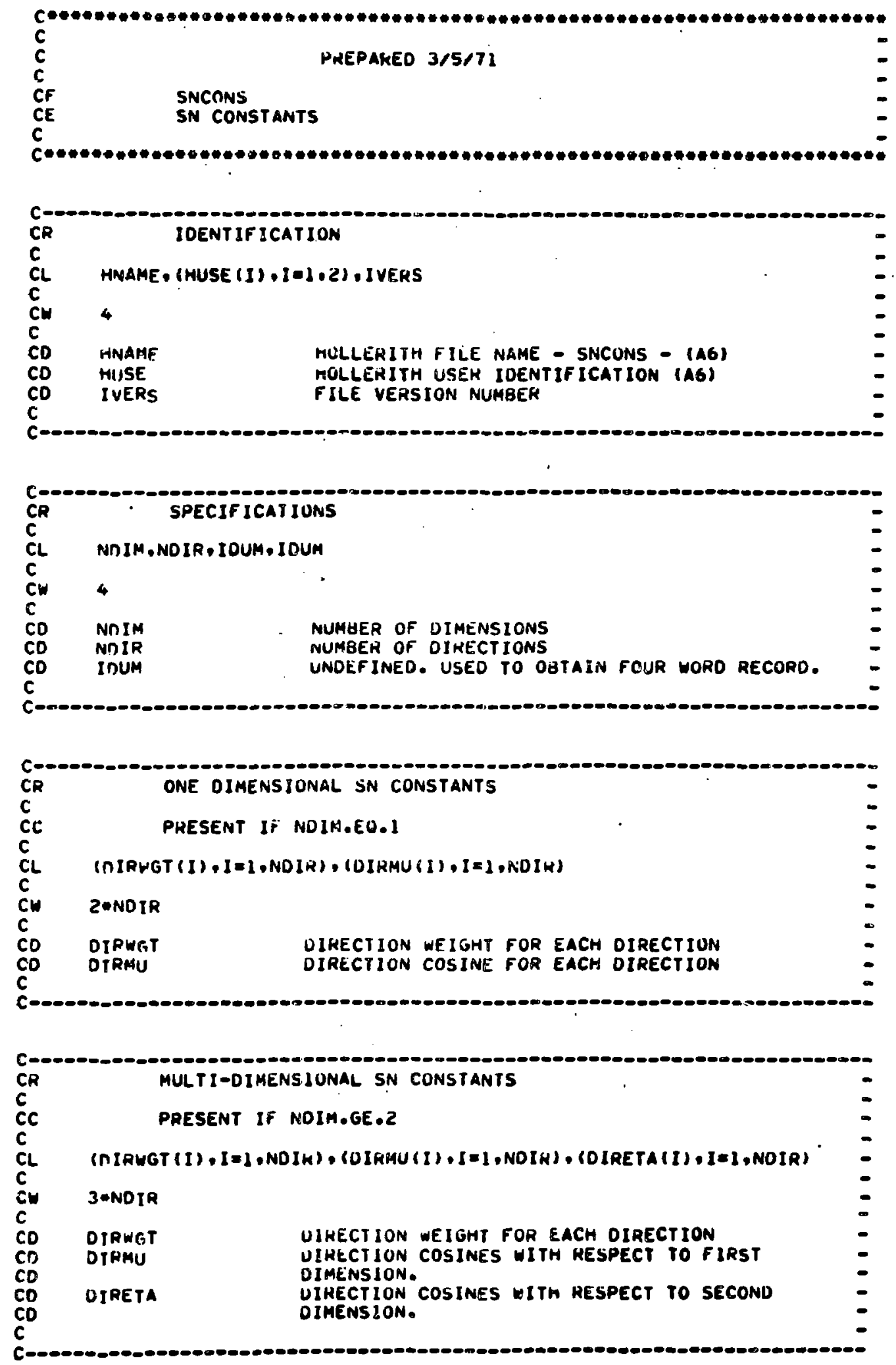

CEOF 


\section{J. FIXSRC}

Thts file provides for dietributed and aurface sources in one, two, or three dimemeions. It vay be used with elther diffusion or Sn codes. D1etributed sources are sources situnted at weh point centers. A directed distributed source can be ueed with $S_{n}$ codes. One application would be to gaman tranaport problems. Legendre coefflctenta are computed in the $S_{n}$ codes whenever anleotroplc ocatterIng is treated. The ane coefficiente can be applied to anisotroplc distributed sourcea. Corsequently, the number of componente of a distzibuted source, NDCOxP, depends upon the order of enieotropy spectfied for scatter 1ng, which, in turn, is limited by the $s_{n}$ order upecified. IDCorp would, therefore, be deterained during input proceseling. NDCOYP $=1$, for diffueion codes.

It 10 axpacter that surface sources w111 be used priarily for coupling separate flux celculatione. These sources reotde on wein point boundertes and, ss such, are necessar1ly dizected sources. The number of components of eurface source NSCOSP 1s two In diffueion theory correaponding to a flux and current at the boundary. NSCOYP equals NDIR, the number of $s_{n}$ directions, in $s_{n}$ celculations.

Meah boundery pointare are used in the file to provide the capability for spectfylng sources at any of the surfaces defined by the meeh.

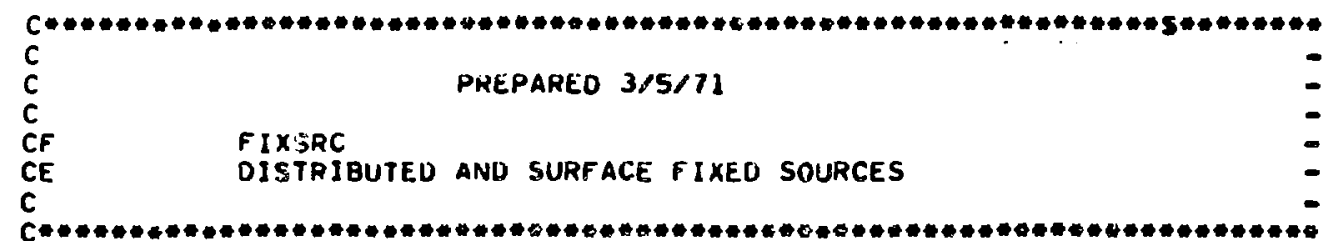

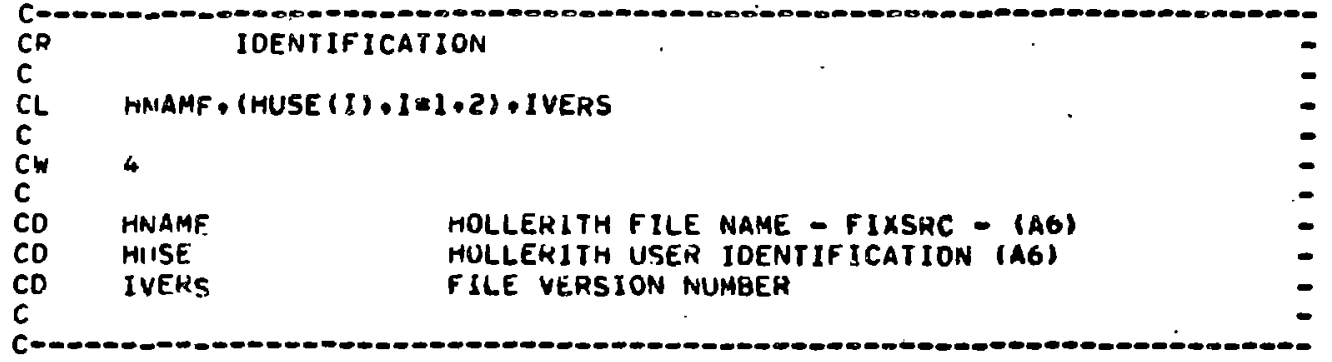

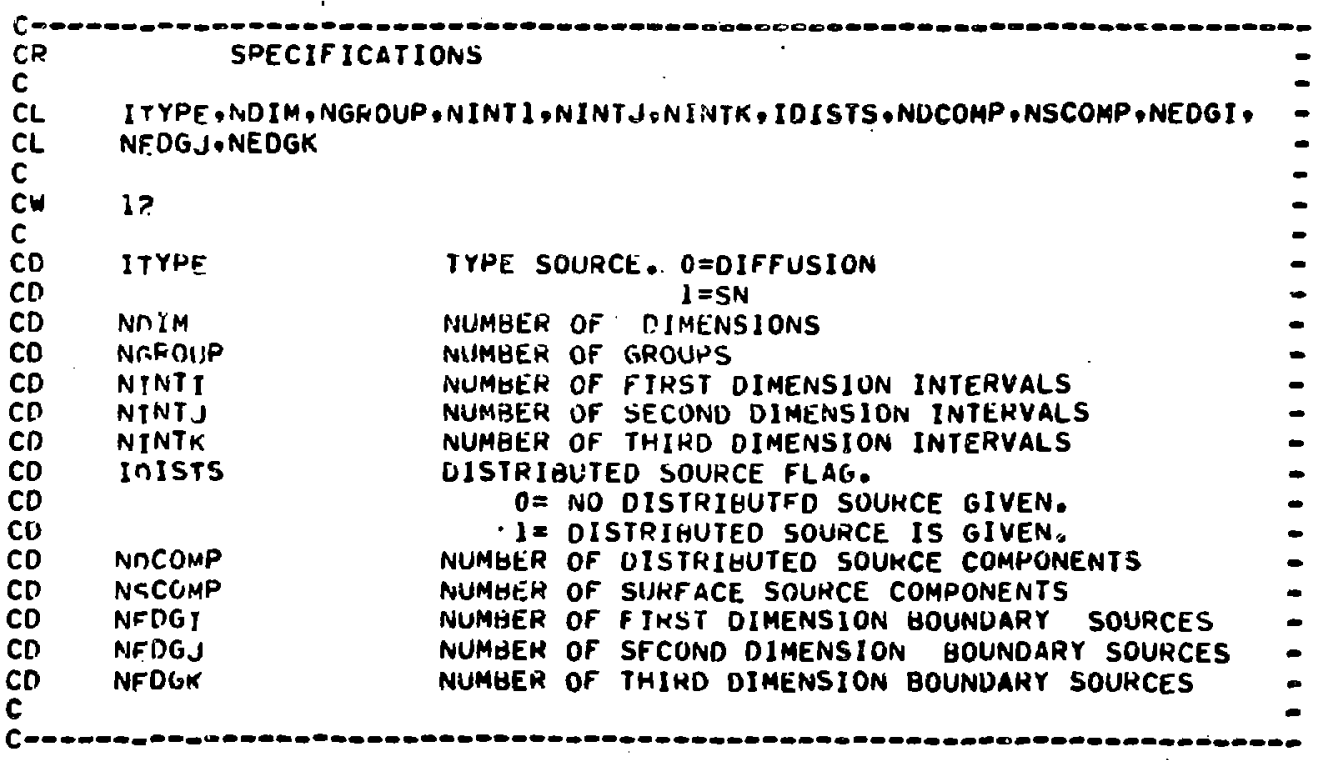



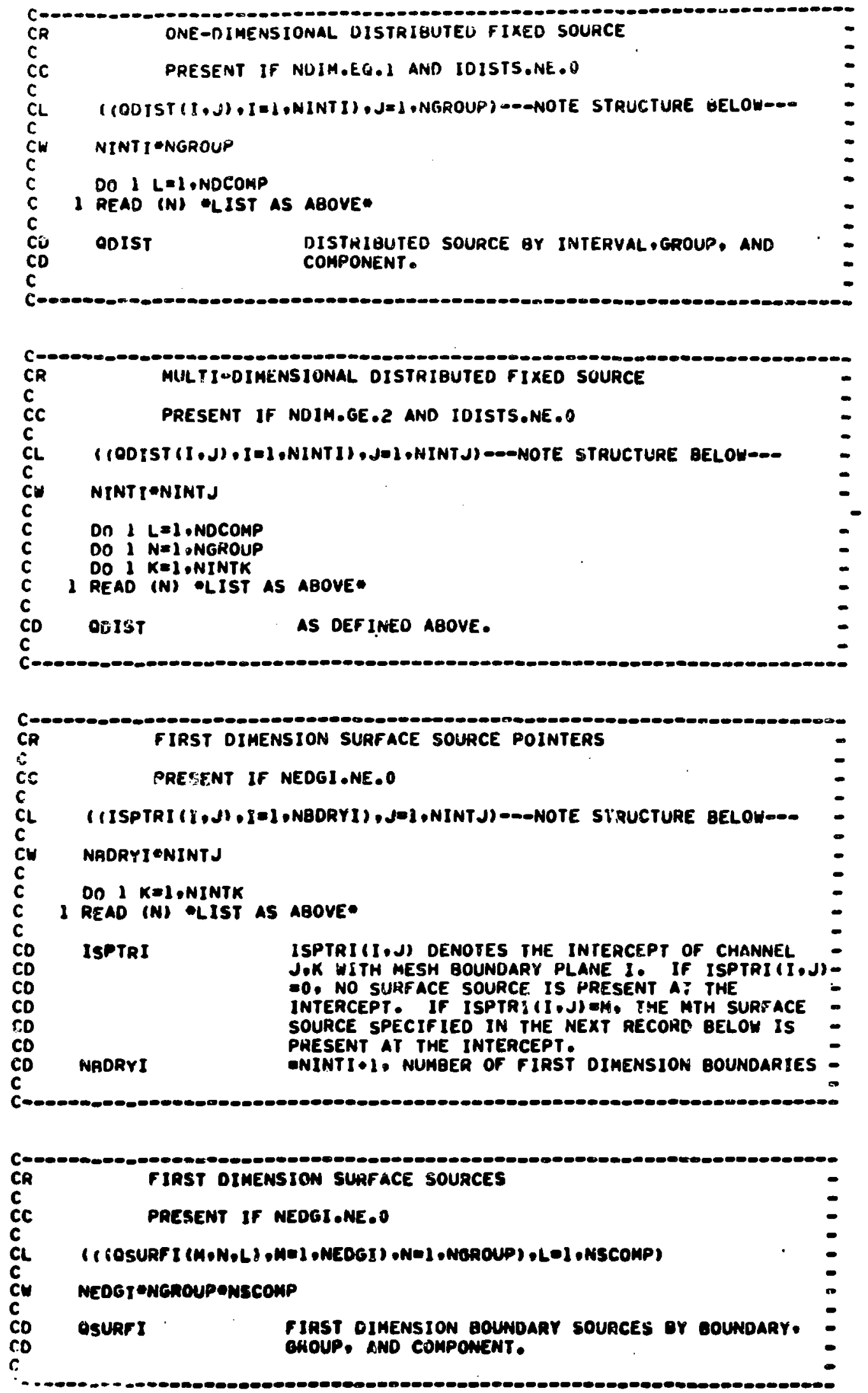


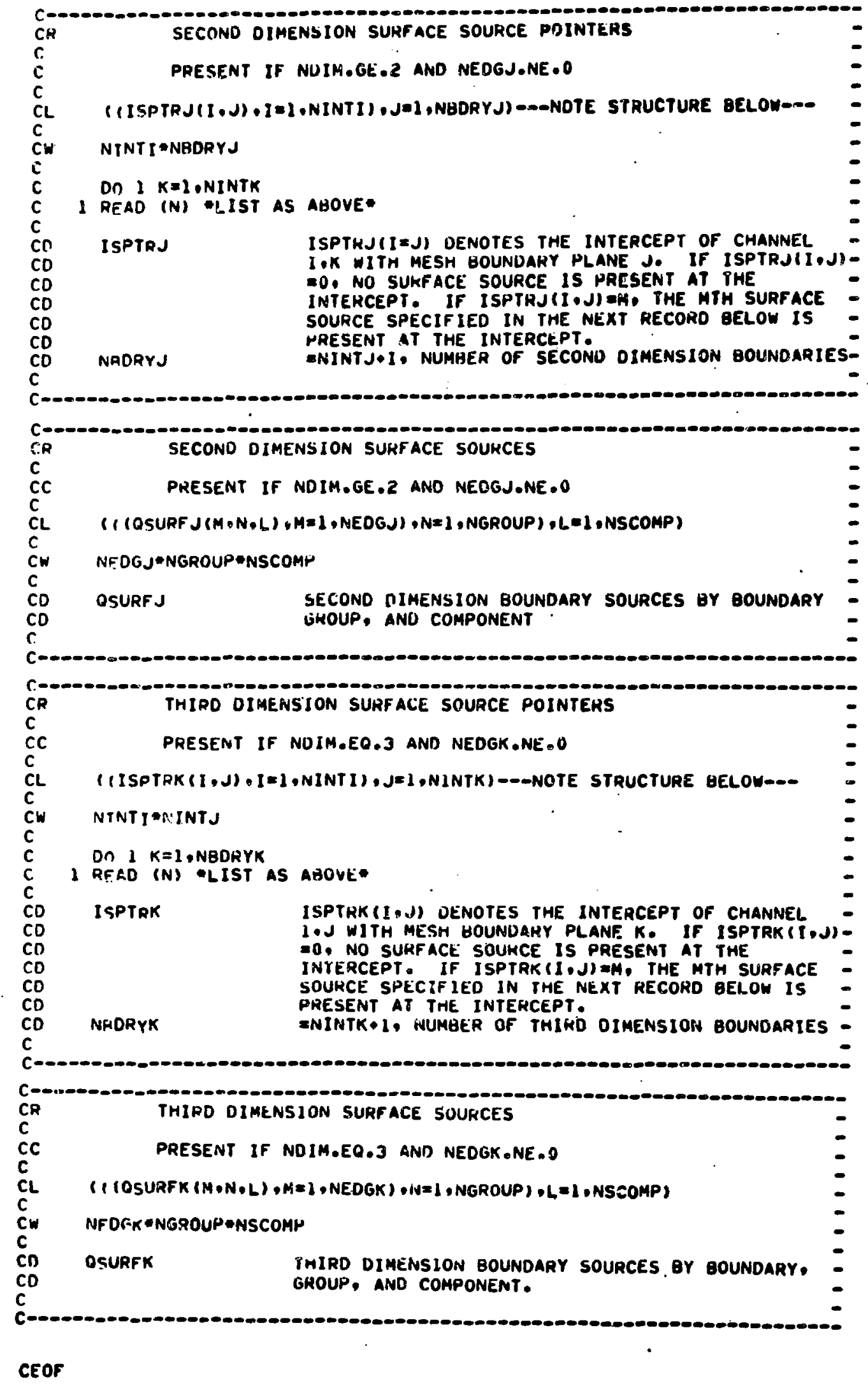




\section{K. RTPLUX and ATFLUX}

Excopt for adepting the epecification to block tranofer and separating the regular from the adfolnt flux, the new apecifications for the total. flux are the same as in the old GXPFLX file. The specification of the group order according to decraalng energy for the raguler caes and according to increasIng energy for the wjolnt cene confores to normal flux code output. This evolds a useleas sort of the adjolnt date and; further, avo1ds a reect when ATFLUX 10 used for rentart.
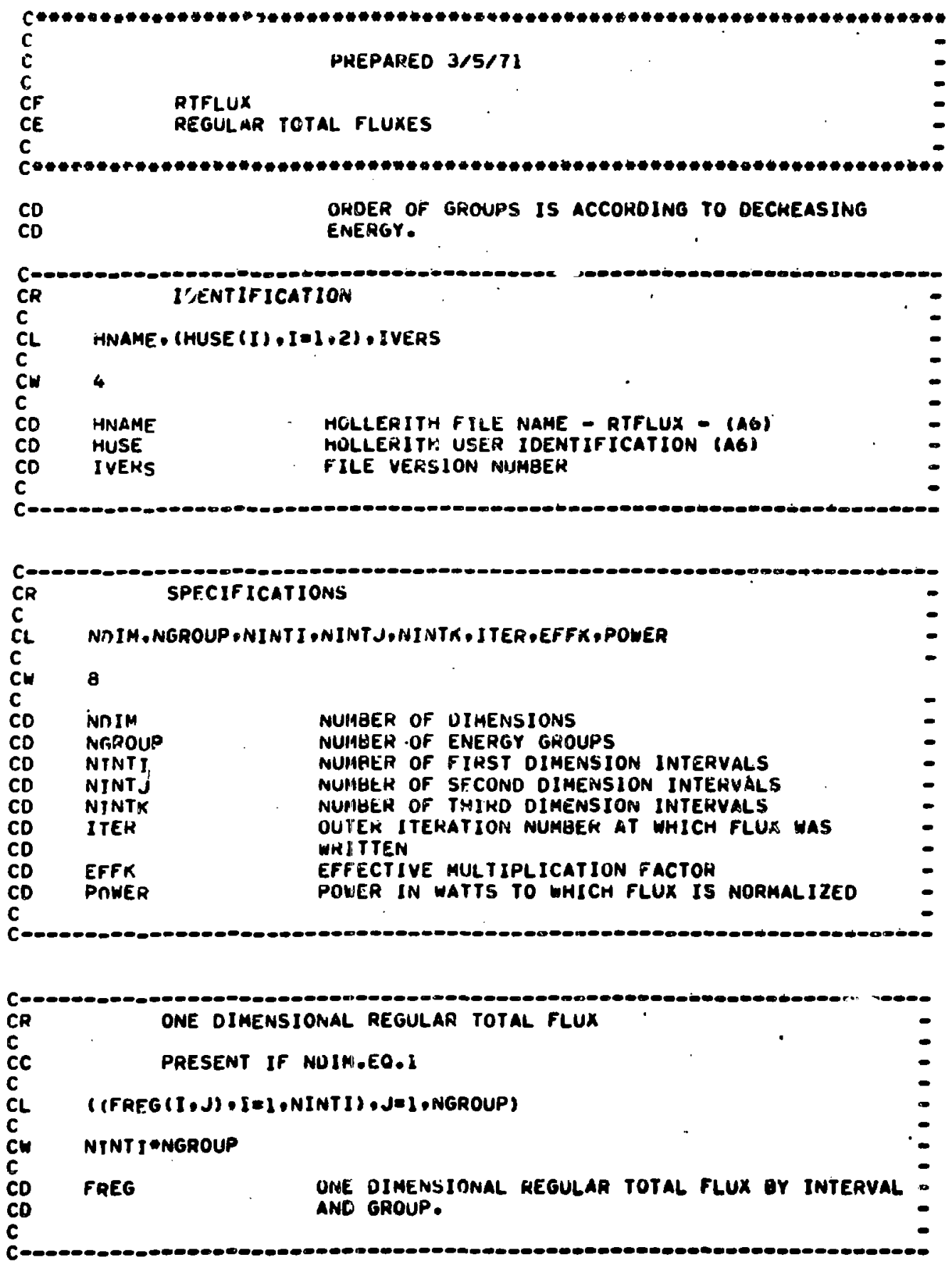


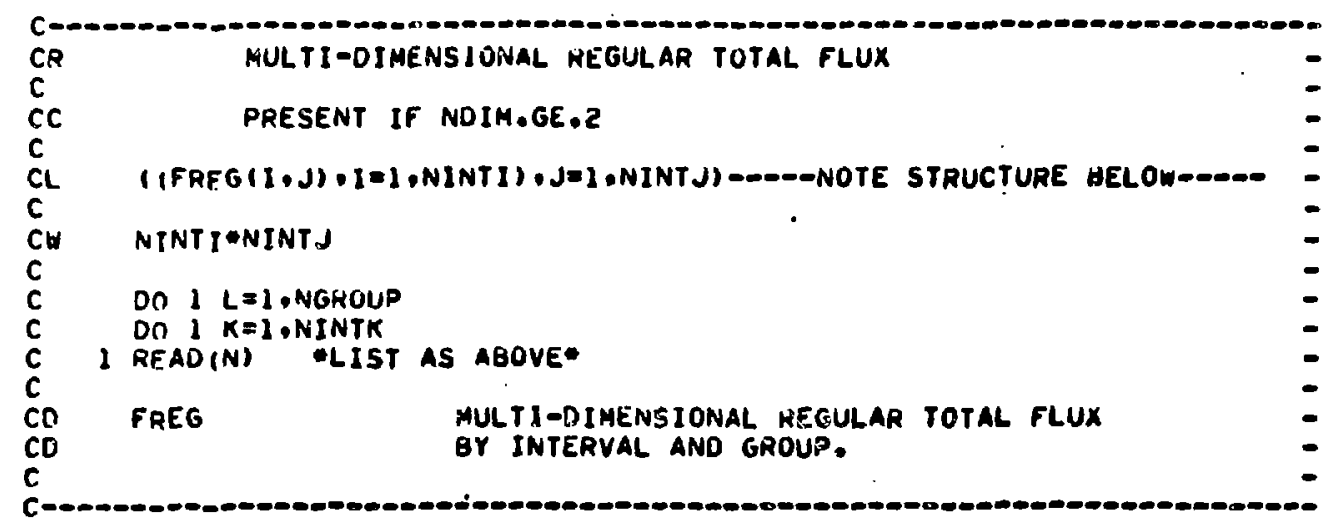

\section{CEOF}

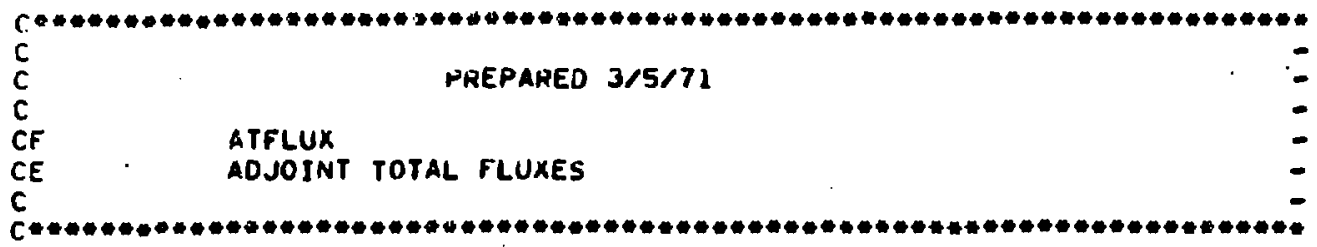

CO URUER OF GROUPS IS ACCOROING TO INCREASING

CO ENEKGY.

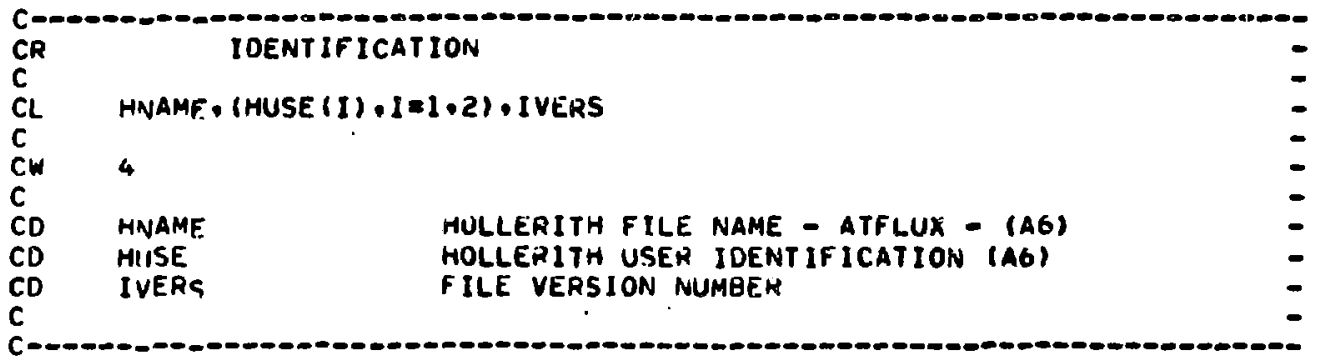

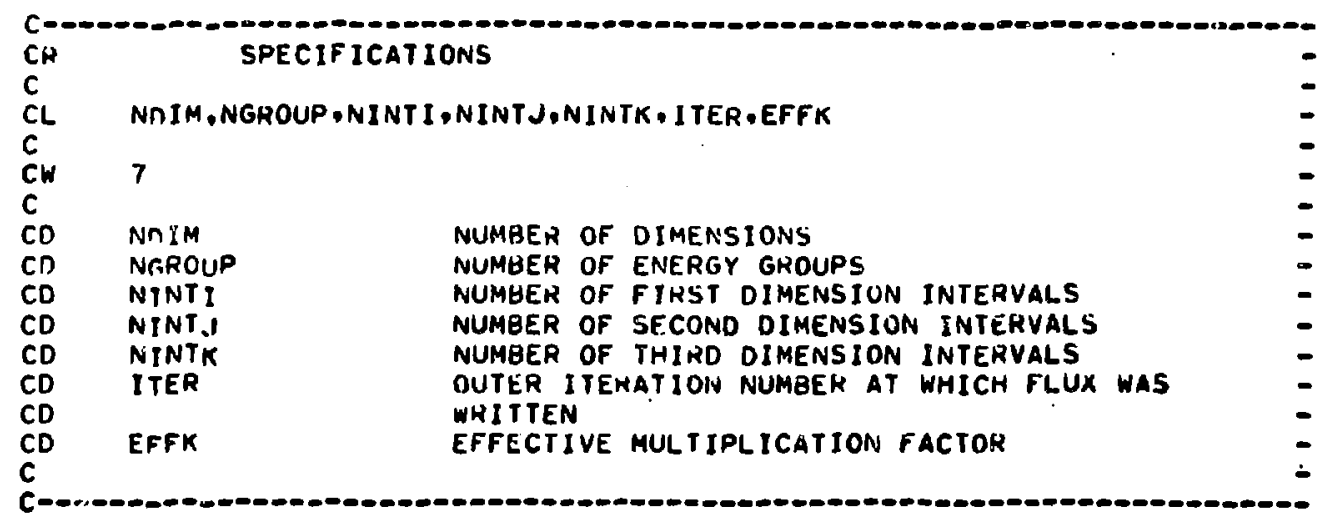




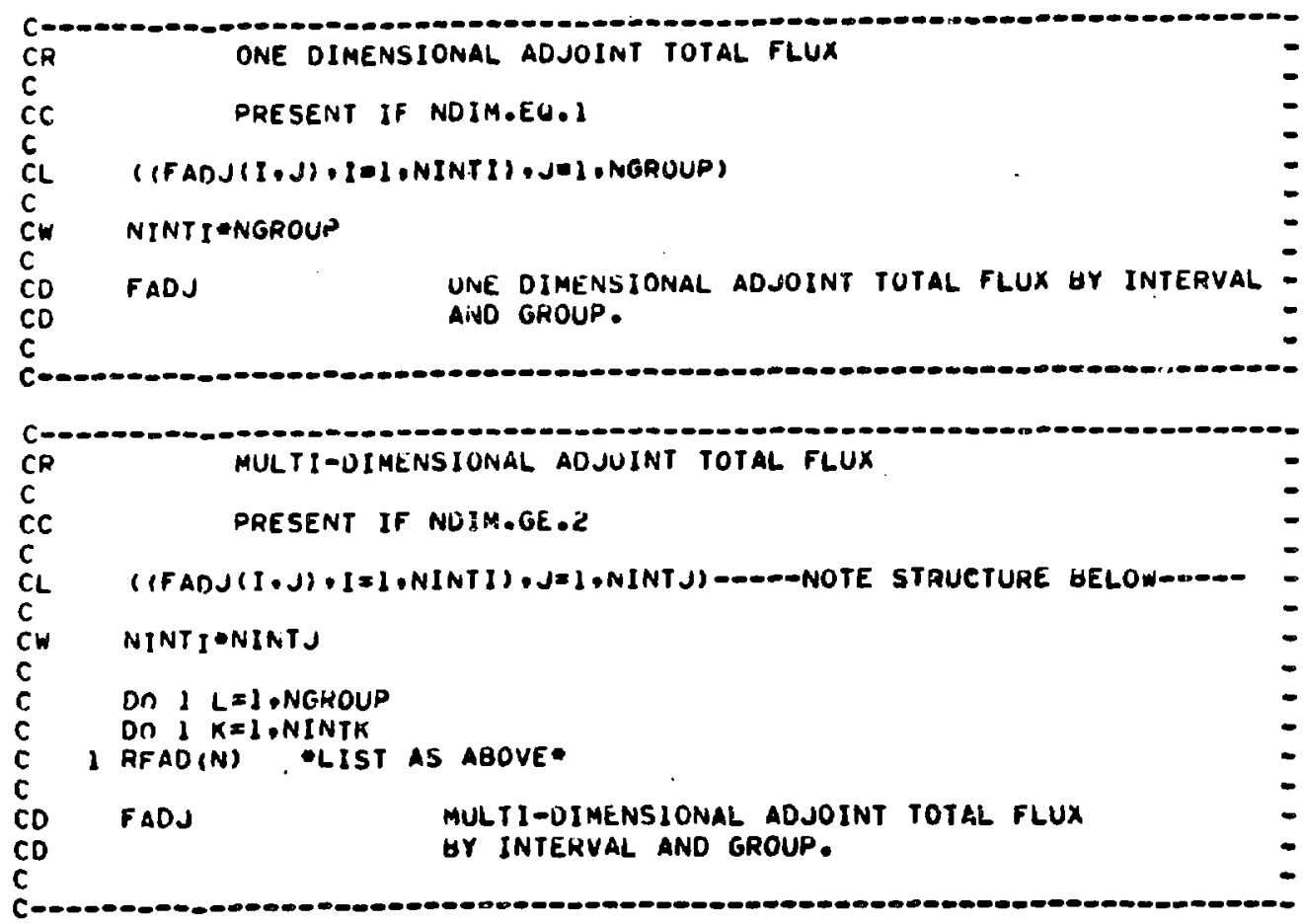

CEOF

1.. RCURNT and ACURNT

In conformnce with the recomendations of the Coumltee, currents have been spacifled at mesh point boundarles rather than at mesh centers. In addition, the mesh-centered values can always be derived simply from the boundary values, but the converse is not true. Boundary currente are somewhat awkwerd to apecify (and treat analytically) In multidimenatonal cases because the current in each direction auec be handled as a separate vector function of the mesh. The order chosen in RCURNT and ACURNT corresponds to an $1, j, k$ sweep over the weah where 1 is varying wost rapidly.

The group ordering if the same as that in the total flux files.

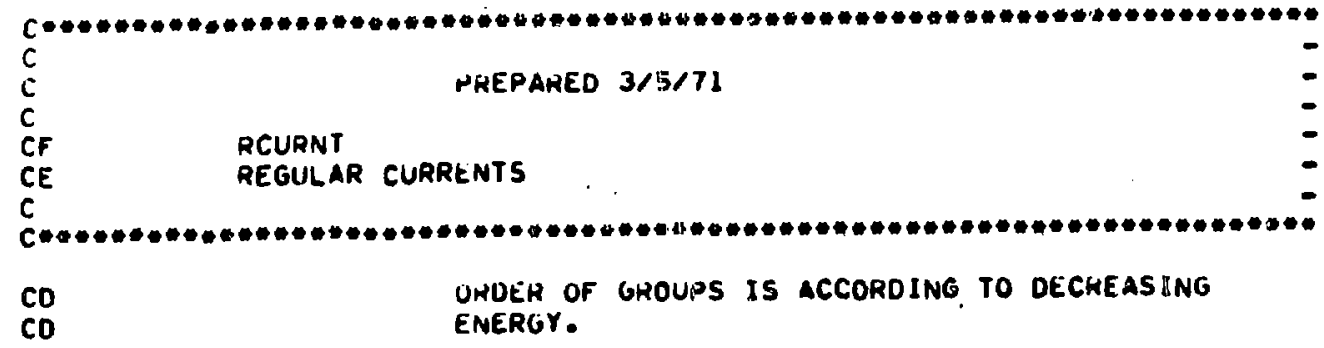



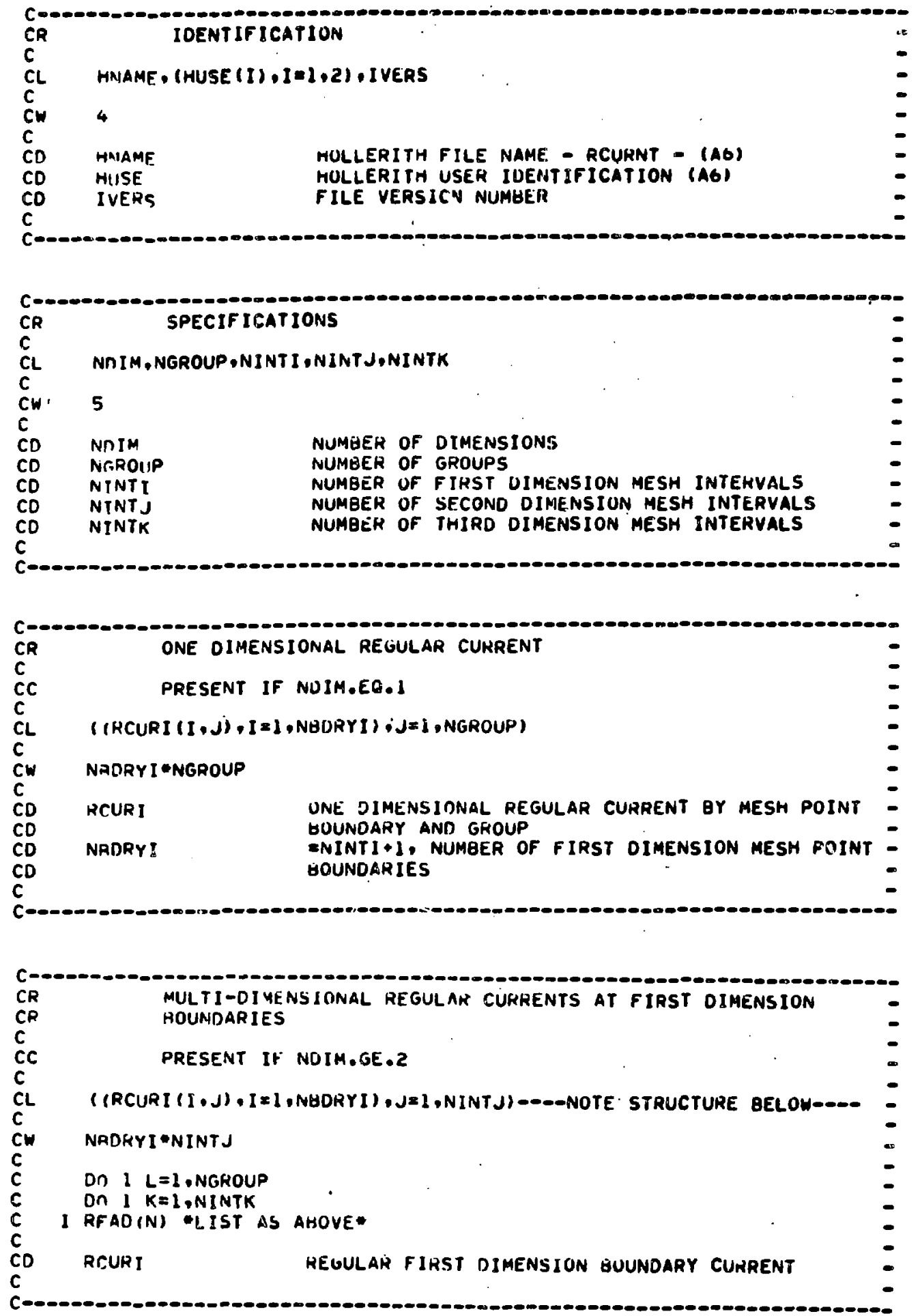

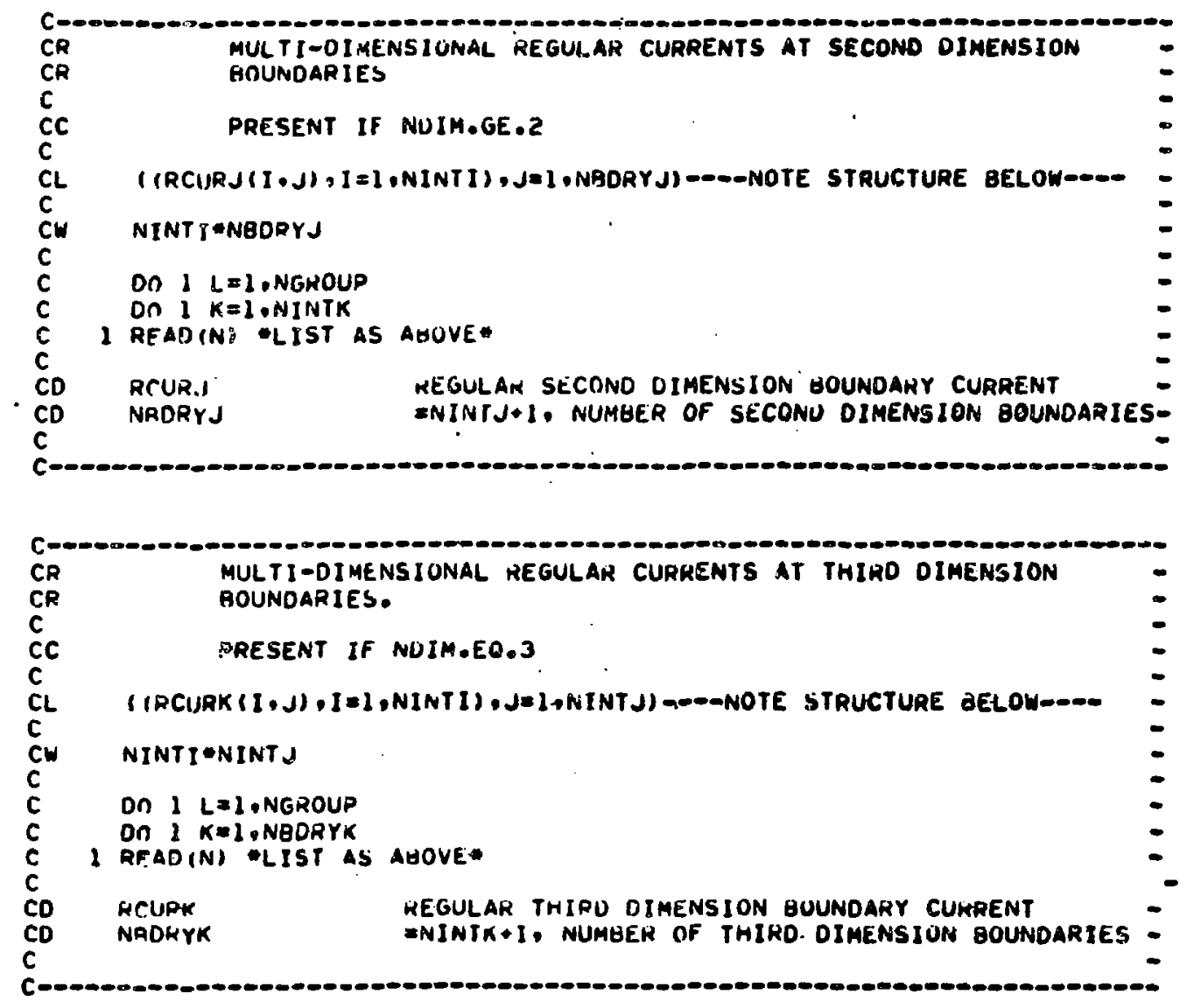

CEOF

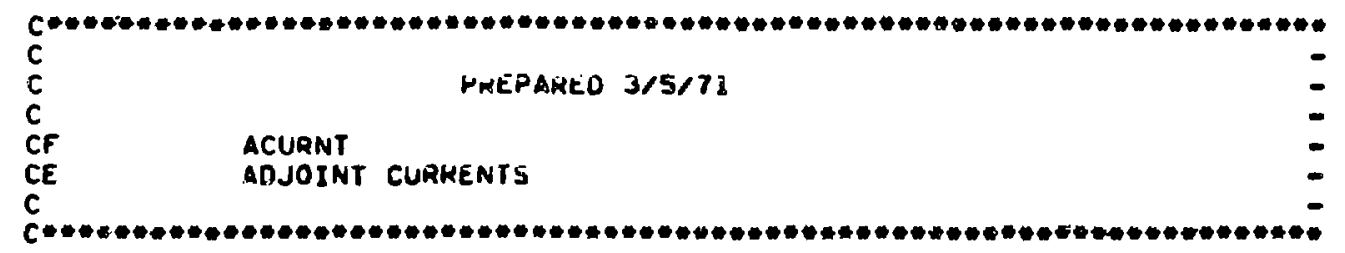

CD OKDEH OF GROUPS IS ACCOROING TO INCKEASING

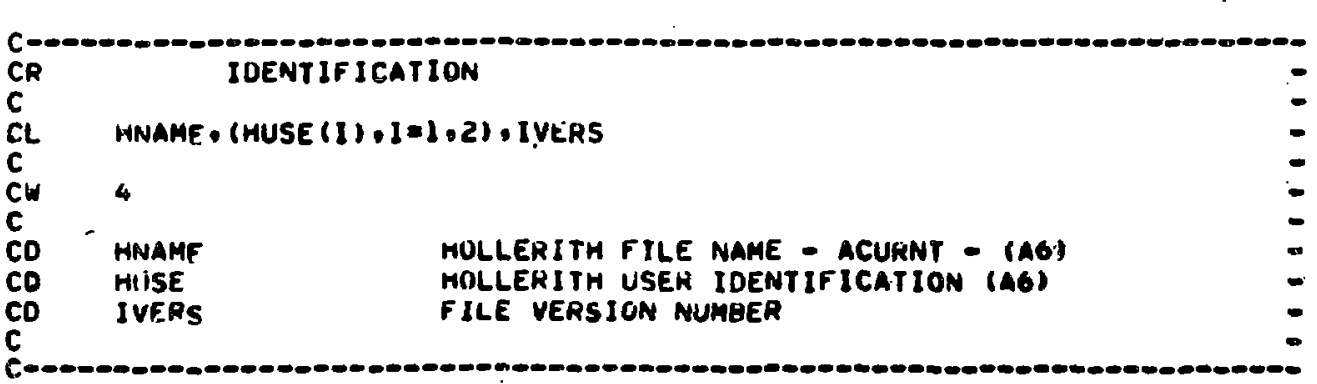



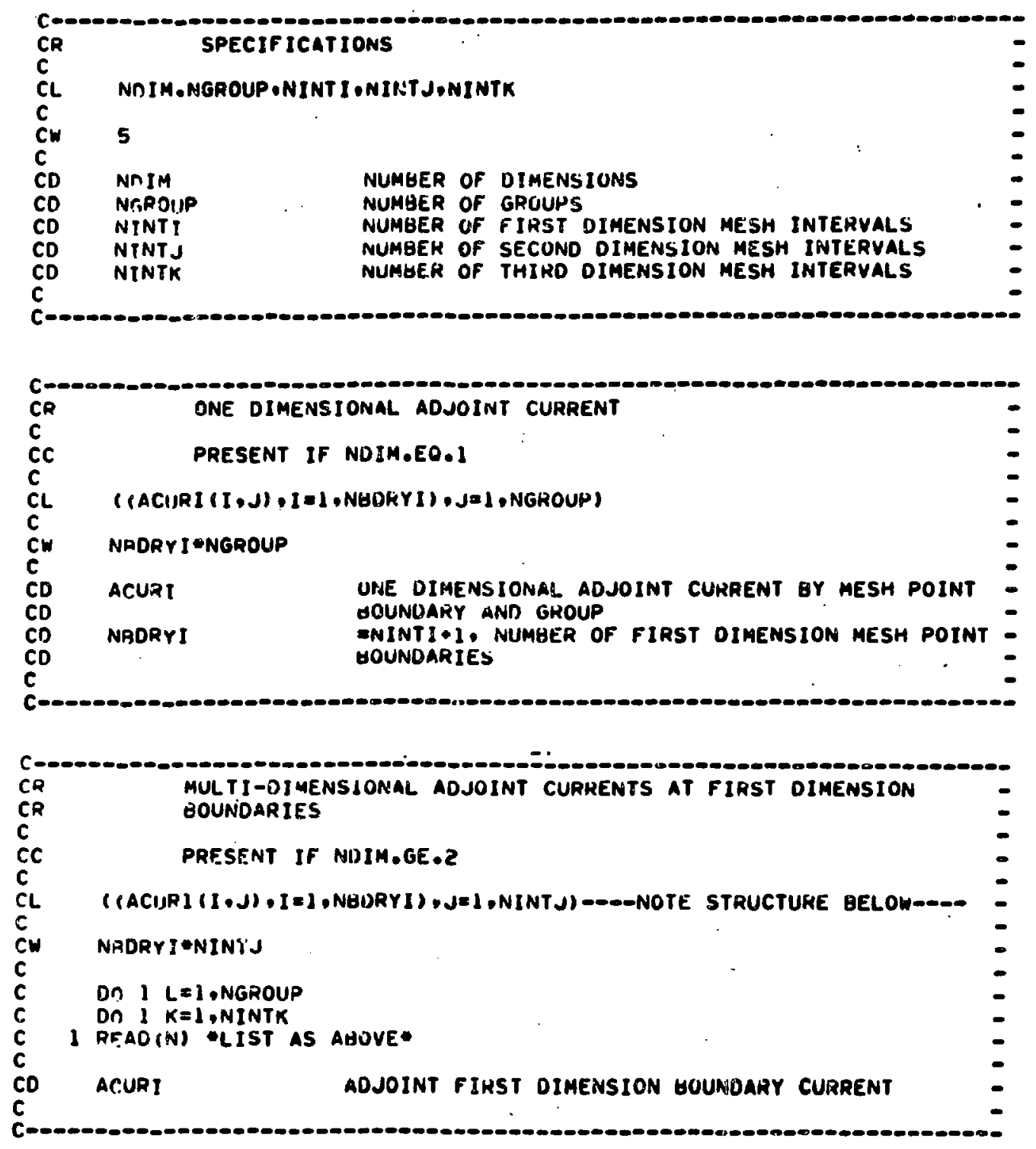

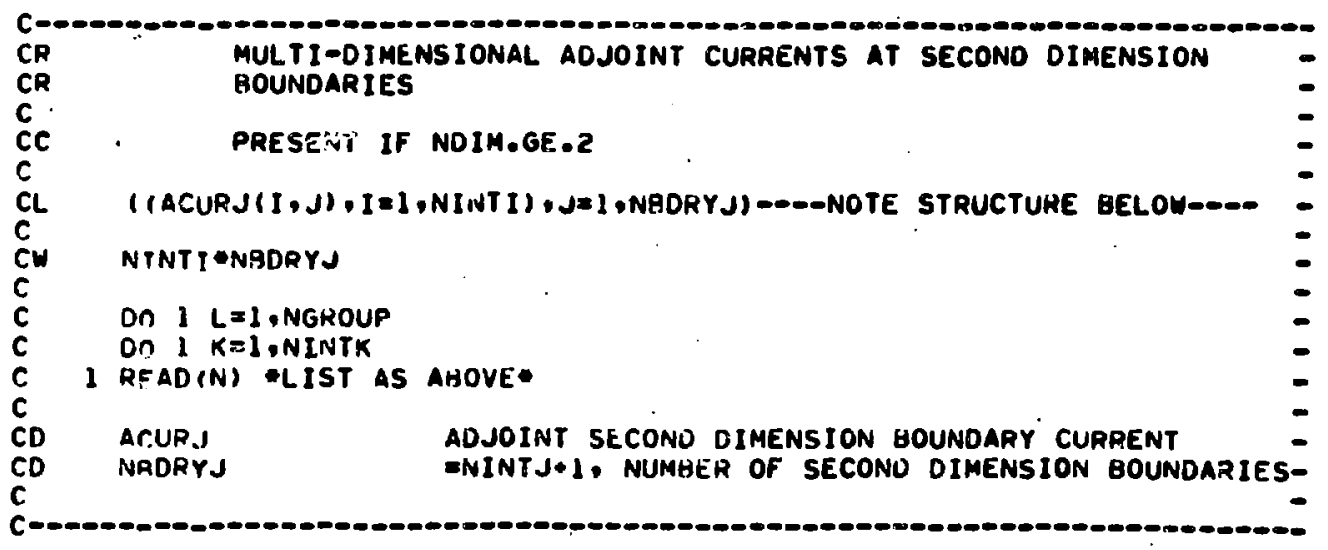




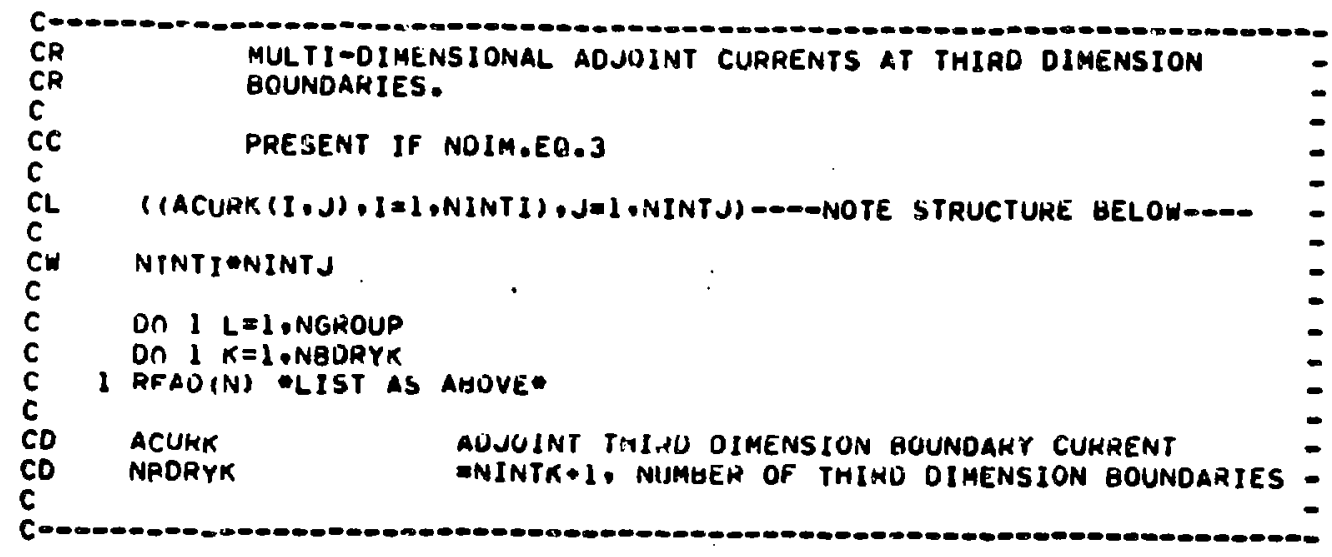

CE OF

\section{PAPLUX and MFLUX}

Mach boundary values for the angular fluxes are apacified, and the etructure of the angular flux files is consietent $x$ ith the etructure of the current files. The angular fluxes AFREG(M) at each weah point boundary may be conbined to obtaln the boundary current using

$$
J=\sum_{M=1}^{\operatorname{NDIR}} \operatorname{DIRWGT}(M) \star \operatorname{DIRCO}(M) * A \operatorname{PREC}(M)
$$

where the DIRWCT are the weighte and the DIRCO are the direction cosines with respect to the given dimens10n. Once th1s tranaformation 18 mede, the ordering of the angular flux data 18 ceen to be equivalent to the ordering of the current date. Because of traneformations performed in $S_{n}$ codes to solve adjolnt probles, the group order of adjoint fluxes is inverse to the regular order, and the direction ansociated wh the fluxes are reflected with reapect to the regular directions. Since for wot application the adjoint ordering is as conventent we the reguler ordering, sorting of the adjoint date to anke 1 confore to the regular ordering 1t not proposed.

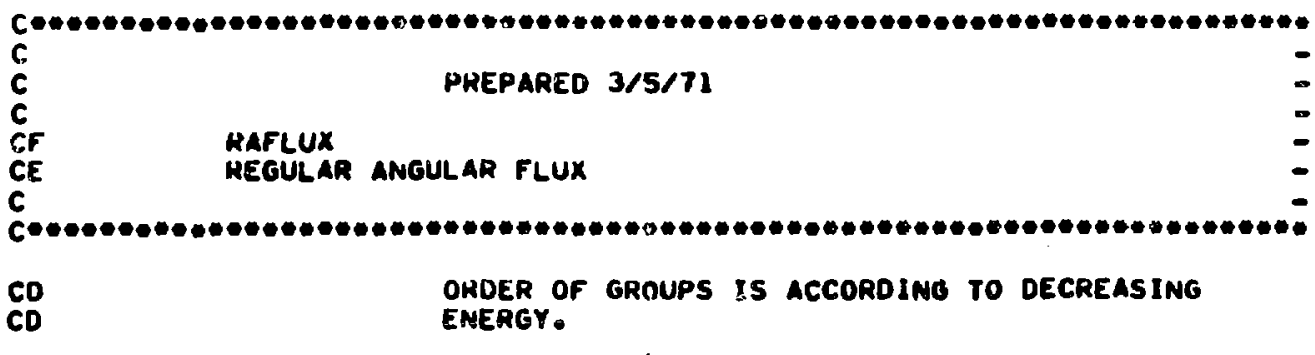

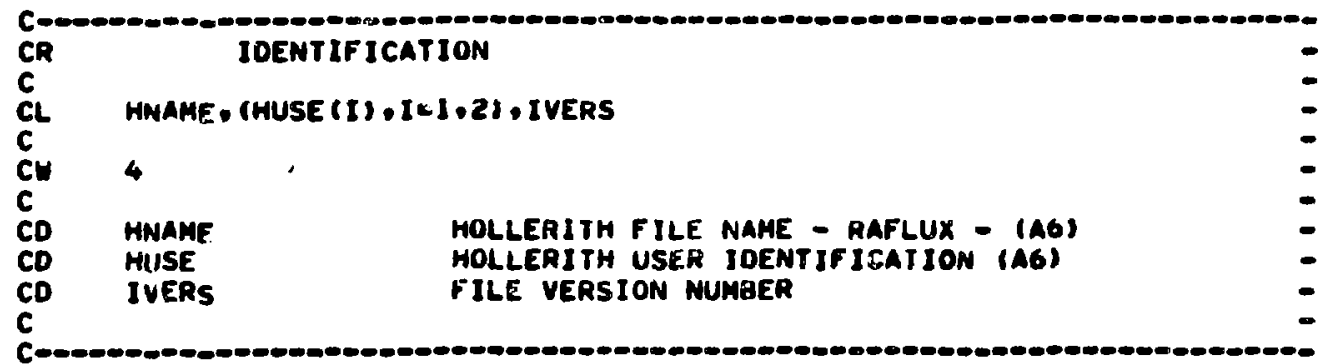



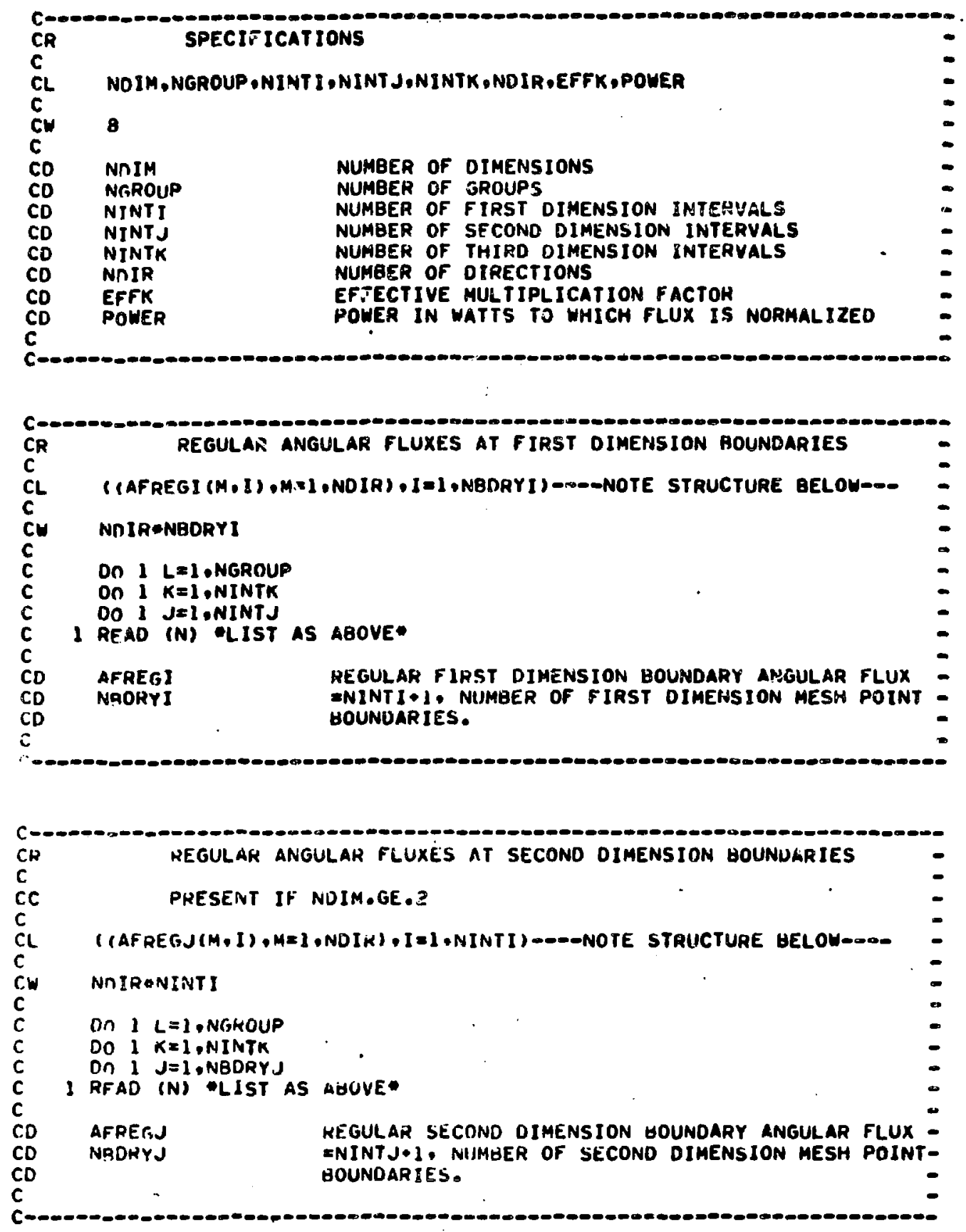


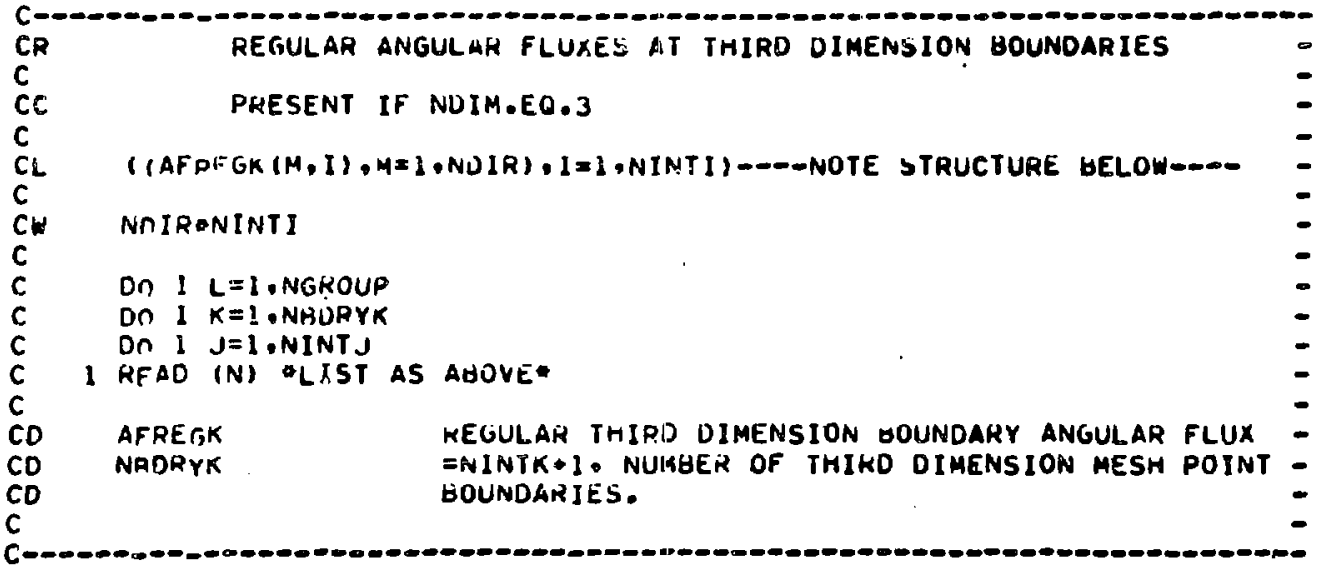

CEOF

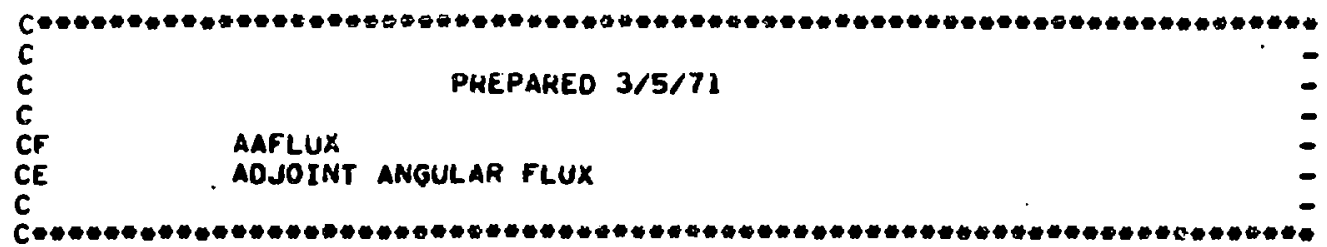

CO ORDER OF GROUPS IS ACCUROING TO INCREASIAG

CO ENERGY. THE DIRECTION NUMBERS MIINDIR DENOTE

CO OIRECTIONS WHICH ARE REFLECTEO WITH RESPECT TO

CD THE DIRECTIONS GIVEN IN THE SNCONS FILE.

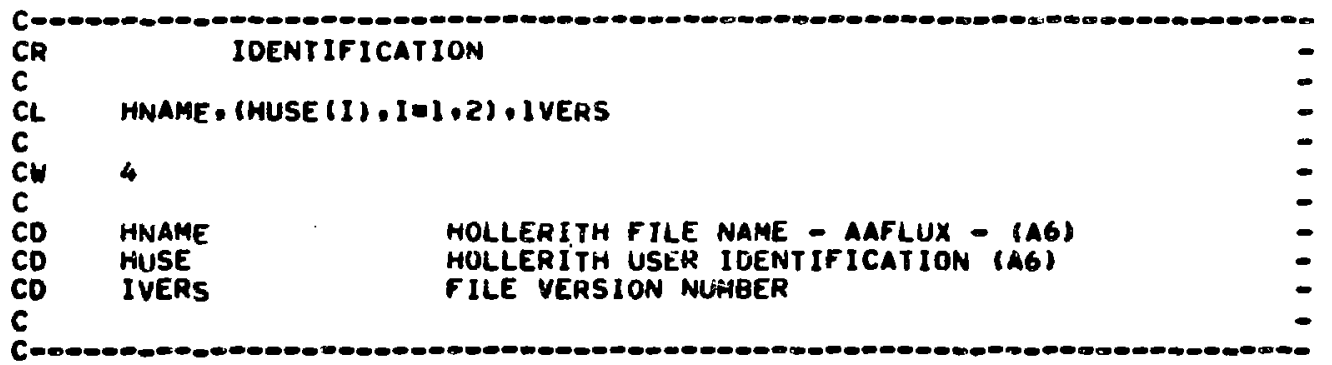

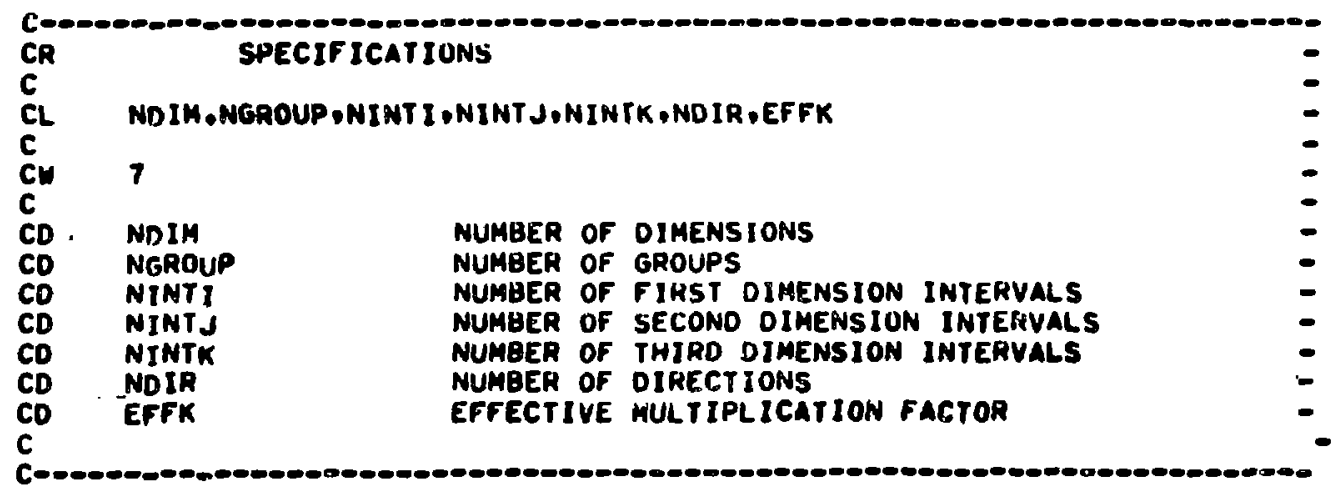



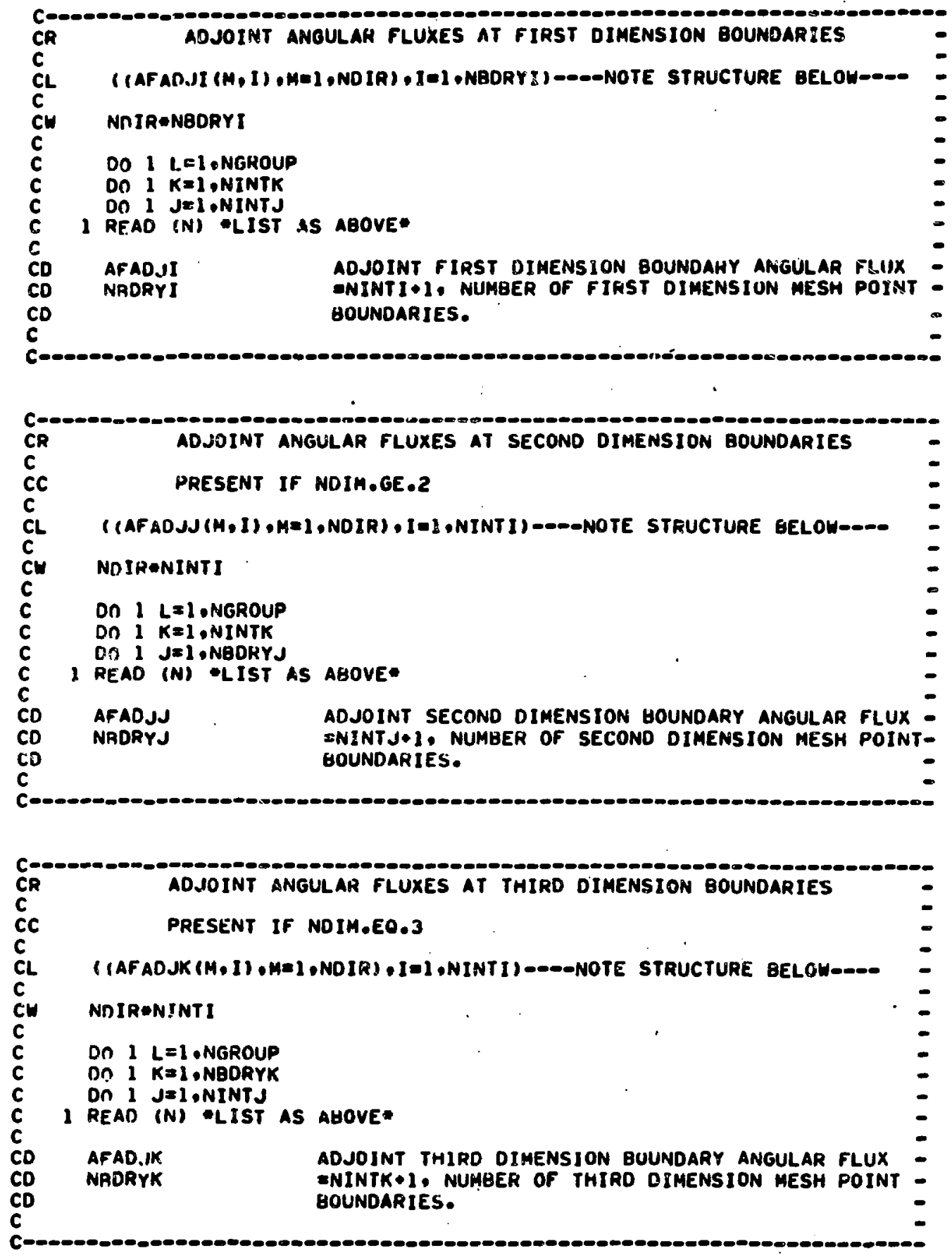

CEOF 


\section{N. REFux}

Th10 f1le contalo e voluneric everege of the regular natren flux by broad anergy grous for each geoneric zone. Also included is reference incegrel data, prianily about the overall seutron balance.

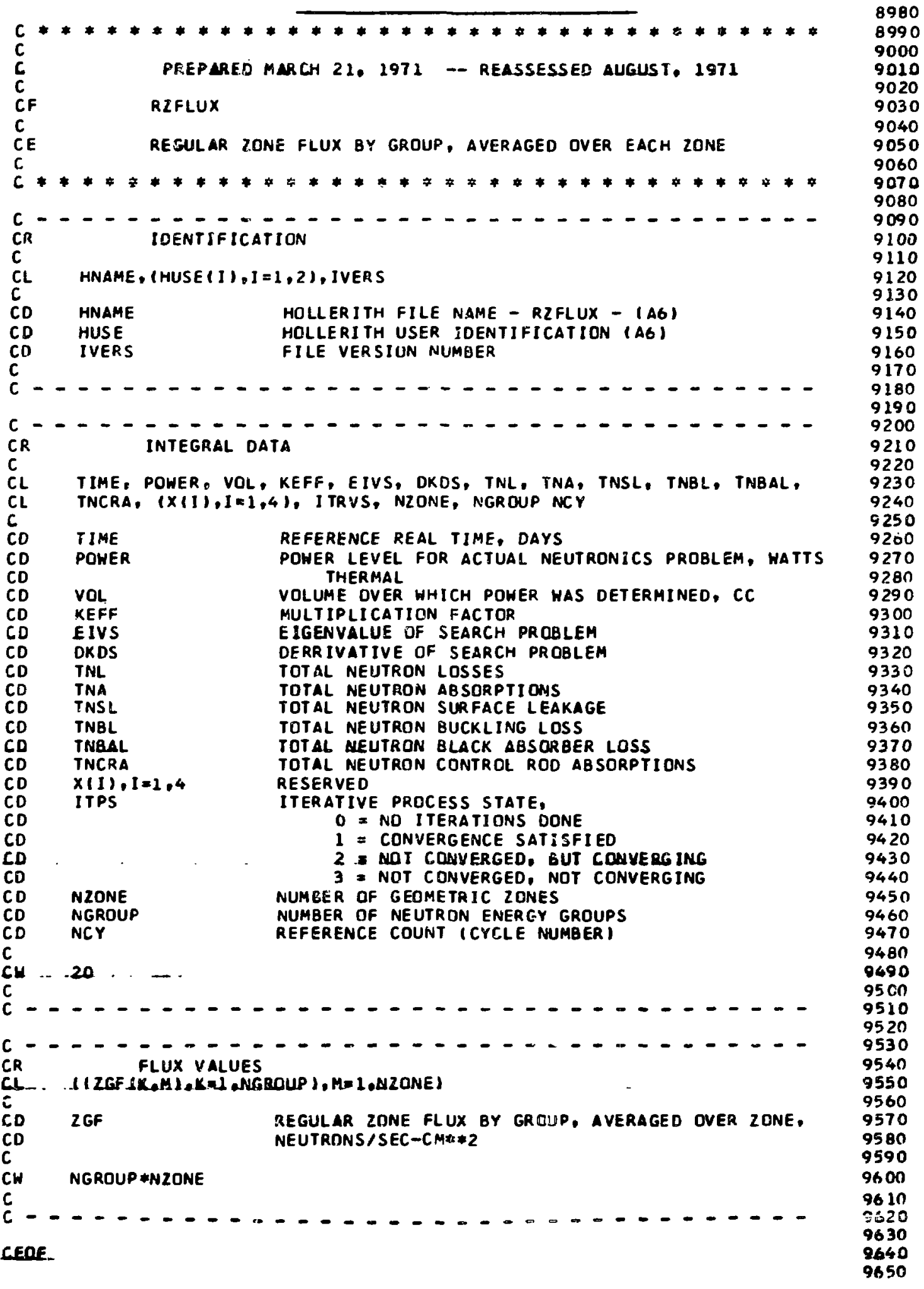




\section{PLDINT}

Th10 f1le conteinu e epece ap of the local theral power denolty by interval. In the event there ars

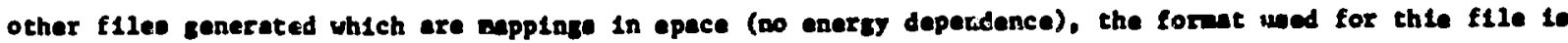
recomended.

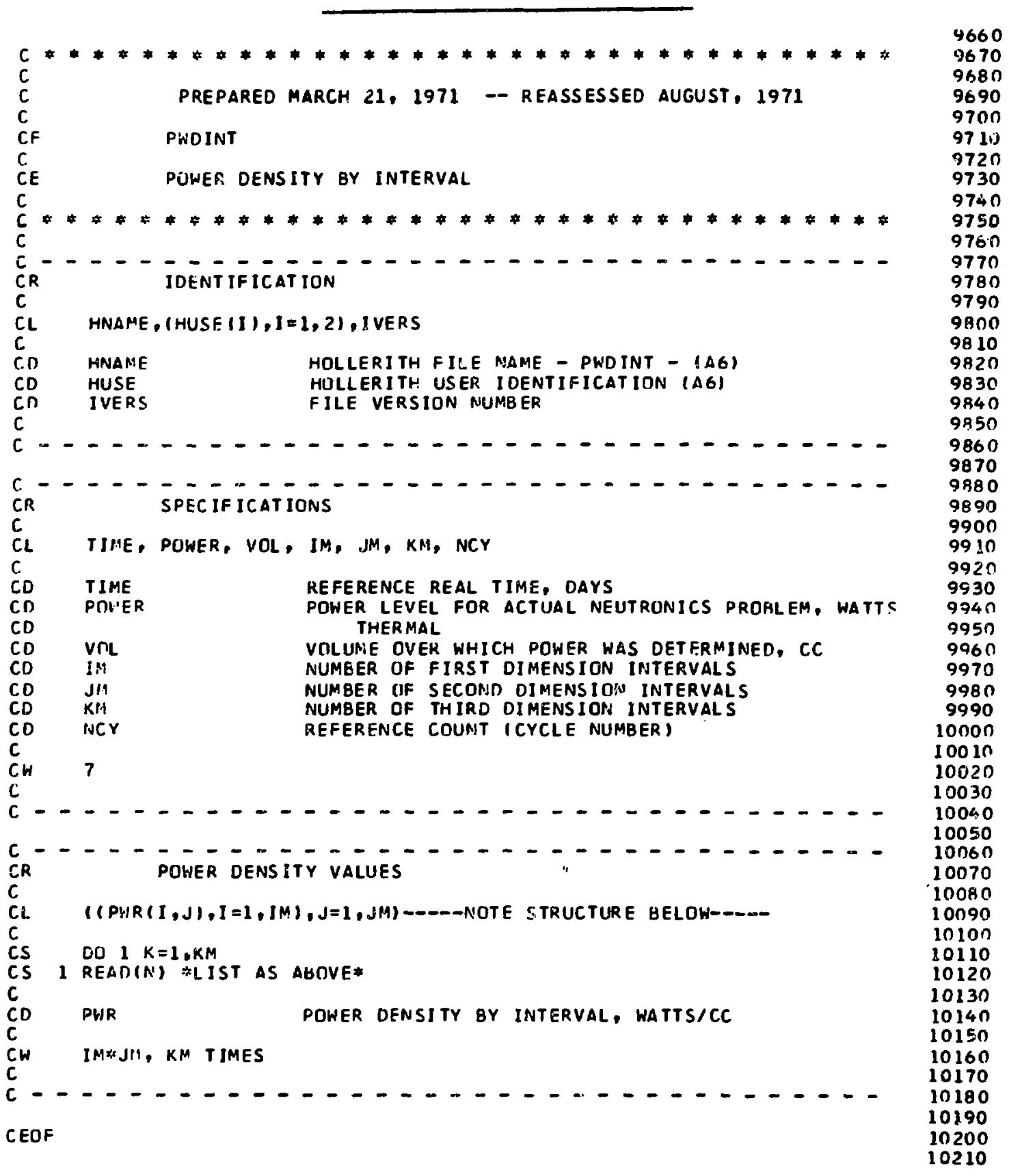

\section{REPERACE}

1. "Report and Reccomendetion of the Comattee on Cosputer Code Coordination," D. K. Dutler, Chatzann,

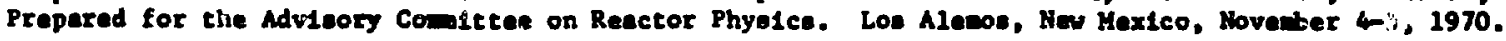

